Steve Ramalho de Amorim Brito

\title{
EXECUÇÃO PROGRESSIVA DA PENA PRIVATIVA DE LIBERDADE: O EXAME CRIMINOLÓGICO NA AVALIAÇÃO SUBJETIVA DO CONDENADO
}

Brasília 
Universidade de Brasília

Faculdade de Direito

\title{
EXECUÇÃO PROGRESSIVA DA PENA PRIVATIVA DE \\ LIBERDADE: O EXAME CRIMINOLÓGICO NA AVALIAÇÃO SUBJETIVA DO CONDENADO
}

\begin{abstract}
Monografia apresentada como requisito parcial para obtenção do grau de Bacharel em Direito pela Universidade de Brasília - UNB
\end{abstract}

Autor: Steve Ramalho de Amorim Brito

Orientador: Professor Álvaro Chagas Castelo Branco

Brasília, janeiro de 2011. 
À Deus,

À Márbylla, minha fiel companheira de todas as horas

Aos meus pais Décio e Maria Ramalho, por tudo que vocês fizeram por mim

A todos os Agentes Penitenciários da Polícia Civil do Distrito Federal, por desenvolvem com excelência essa árdua tarefa 
Agradeço ao Professor Álvaro Chagas Castelo Branco, por se dispor a me orientar durante a etapa final de realização do trabalho.

Agradeço também aos Professores Luís Martius Holanda Bezerra Júnior e Aldo de Campos Costa, por me ajudarem a definir o norte para o desenvolvimento de minha monografia. 


\section{RESUMO}

O presente trabalho, apresentado para obtenção do grau de Bacharel em Direito pela Universidade de Brasília - UNB, procura analisar como é realizada a avaliação do critério subjetivo do apenado na progressão de seu regime prisional. No Brasil a execução da pena privativa de liberdade é realizada de forma progressiva, onde o condenado avança gradativamente em direção á liberdade conforme seu mérito demonstrado durante a execução da reprimenda penal. Até a edição da Lei 10.792/2003, o exame criminológico era o principal instrumento técnico utilizado para se obter as informações que subsidiavam a avaliação desse mérito. A partir de 2003, o legislador preferiu dispor da obrigatoriedade do exame e passar a avaliar o mérito com base no comportamento do apenado durante a execução da pena. Essa modificação conseguiu dar fluência aos pedidos de progressão que antes ficavam travados em razão da inércia estatal para realização do exame. No entanto, diversos apenados beneficiados com a progressão demonstram não possuir condições pessoais para cumprir sua pena em um regime mais brando, o que reflete a precariedade do atual modelo vigente. No presente trabalho, realizamos uma critica ao atual modelo de avaliação do mérito e apontamos para a necessidade de modificações para que o sistema possa cumprir seus objetivos de efetivar o cumprimento das disposições da sentença condenatória e possibilitar condições necessárias à reintegração social do condenado. $\mathrm{Na}$ abordagem do tema, apresentamos os dispositivos legais que regulamentaram a execução penal brasileira no período republicano, destacando os diversos projetos de codificação para o Direito da Execução Penal e que culminaram com a edição da Lei de Execução Penal em 1984. Também tratamos das particularidades do exame criminológico e demais instrumentos utilizados na avaliação dos aspectos subjetivos do condenado durante a execução da pena na sistemática original da Reforma Penal de 1984. Em seguida apresentarmos as modificações introduzidas pela Lei 10.792/2003 e passamos a discutir os posicionamentos doutrinários em relação à admissibilidade da realização do exame criminológico para aferição do mérito do apenado desde então. Apresentamos ainda a evolução dos posicionamentos jurisprudenciais do STF e do STJ sobre o assunto em tela e as propostas de alterações legislativas em tramitação no Congresso Nacional.

Palavras chave: execução penal, progressão de regime prisional, mérito, exame criminológico, requisitos subjetivos do condenado. 


\section{LISTA DE ABREVIATURAS}

- AgR: Agravo Regimental

- CFB: Constituição Federal brasileira de 1988

- CNPCP: Conselho Nacional de Política Criminal e Penitenciária

- CPB: Código Penal brasileiro (Decreto Lei N² 2.848, de 7 de dezembro de 1940)

- CPP: Código de Processo Penal brasileiro (Decreto Lei N 3.689, de 3 de outubro de 1941)

- CTC: Comissão Técnica de Classificação

- HC: hábeas corpus

- LEP: Lei de Execução Penal (Lei $N^{\circ} 10.792$, de $1^{\circ}$ de dezembro de 2003).

- MP: Ministério Público

- PL: Projeto de Lei da Câmara Federal

- PLS: Projeto de Lei do Senado Federal

- RDD: Regime Disciplinar Diferenciado.

- REsp: Recurso Especial

- RIEP: Regimento Interno dos Estabelecimentos Penais do Distrito Federal (Portaria $\mathrm{N}^{\circ} 001$ de 11/01/1988 da Secretaria de Segurança Pública do DF)

- STF: Supremo Tribunal Federal;

- STJ: Superior Tribunal de Justiça; 


\section{SUMÁRIO}

INTRODUÇÃ̃O

1 SÍNTESE TEMÁTICA E ANTECEDENTES HISTÓRICOS 6

1.1 A pena privativa de liberdade e as escolas penais 6

1.2 O Direito da Execução Penal: conceito, autonomia e princípios informadores 9

1.3 Execução científica, individualização da pena e classificação dos condenados 11

1.4 Os regimes de execução penal, sistemas penais e a evolução do condenado no sistema progressivo 14

1.5 Avaliação dos apenados e o conceito de mérito 16

2 OS ANTECEDENTES LEGISLATIVOS E A REGULAMENTAÇÃO DO DIREITO DA EXECUÇÃO PENAL NO BRASIL ANTES DA REFORMA DE 1984 20

2.1 As propostas de codificação para o Direito da Execução Penal 20

2.1.1 O Projeto de Código Penitenciário de 1933 20

2.1.2 Anteprojeto de Código Penitenciário de 1957 21

2.1.3 Anteprojeto do Código das Execuções Penais de 1963 23

2.1.4 Anteprojeto de Código Penitenciário de 1970 24

2.2 A regulamentação da execução penal brasileira no período republicano 26

3 A REFORMA PENAL DE 1984 E A LEI DE EXECUÇÃO PENAL 33

3.1 Generalidades 33

3.2 As modalidades da pena, os estabelecimentos penitenciários e os regimes de execução penal 36

3.3 A individualização penal nas fases de conhecimento e de execução e a progressão de regime prisional 38

3.4 Critério subjetivo para a progressão: a questão do mérito 41

4 A AVALIAÇÃO DOS ASPECTOS SUBJETIVOS DO CONDENADO E O EXAME CRIMINOLÓGICO NA REFORMA DE 1984 44

4.1 A diferenciação entre exame de personalidade e exame criminológico 44

4.2 Parecer da Comissão Técnica de Classificação 45 
4.3 O exame criminológico 47

4.3.1 Conceito e definição ___ 47

4.3.2 Finalidade e objetivos __ 48

4.3.3 A natureza jurídica___ 49

4.3.4 Conteúdo — 50

4.3.5 Antecedentes históricos e momento de realização___ 51

4.3.6 O exame criminológico de entrada. __ 54

4.3.7 O exame criminológico nos pedidos de progressão de regime prisional ___ 55

4.4 Problemas e limites do exame criminológico ___ 56

5 A PROGRESSÃO DE REGIME APÓS A LEI 10.792/2003: A AVALIAÇÃO DOS CRITÉRIOS SUBJETIVOS E O EXAME CRIMINOLÓGICO 61

5.1 Os novos critérios subjetivos para a progressão e as novas atribuições da Comissão Técnica de Classificação 61

5.2 Posicionamentos doutrinários a respeito do exame criminológico na análise dos pedidos de progressão de regime prisional 64

5.3 Jurisprudência sobre a realização do exame criminológico nos pedidos de progressão de regime prisional 79

5.3.1 Jurisprudência do STF 79

5.3.2 Jurisprudência do STJ 85

\section{CRÍTICA A RESPEITO DAS MUDANÇAS INTRODUZIDAS PELA LEI}

10.792/2003 E PROPOSTAS DE NOVAS ALTERAÇÕES LEGISLATIVAS 92

6.1 Criticas sobre o posicionamento doutrinário 92

6.2 Análise da jurisprudência do STF e do STJ 94

6.3 Projetos de alterações legislativas 97

CONCLUSÕES 100

REFERÊNCIAS BIBLIOGRÁFICAS 105

BIBLIOGRAFIA DE APOIO 108 


\section{INTRODUÇÃO}

Em 11 de junho de 2009, a Lei de Execução Penal completou 25 anos de existência. Com a Reforma Penal de 1984, o Direito da Execução Penal ${ }^{1}$ brasileiro ganhou autonomia como ramo autônomo do Direito Público frente ao Direito Penal, Direito Processual Penal e Direito Administrativo, sendo esta a primeira vez no país que se editou uma lei específica regulamentar os diversos institutos jurídicos da execução penal.

Porém, após um quarto de século, percebemos que a Lei de Execução Penal não tem se mostrado totalmente eficaz em cumprir os seus objetivos de efetivar o cumprimento das disposições da sentença condenatória e possibilitar condições necessárias à reintegração social do condenado. Isso tem ocorrido devido a uma série de fatores políticos, sociais e econômicos que, ao longo dos anos, levaram o sistema penal brasileiro a uma condição que praticamente impossibilita o cumprimento rigoroso de diversos dispositivos desse diploma legal.

Tendo consciência desse panorama, gostaríamos de poder discorrer a respeito da influencia dos principais fatores que têm diminuído a credibilidade das instituições públicas responsáveis pela execução penal no país. No entanto, sabemos que no contexto de um trabalho final de graduação em Direito devemos nos ater a problemas pontuais e analisálos de modo mais completo possível. Assim, dentro do Direito da Execução Penal nos propomos a discorrer a respeito da execução progressiva da pena privativa de liberdade. Dentro desse ponto, limitaremos nossa abordagem á temática relativa à aferição dos requisitos subjetivos do condenado na ocasião da progressão do regime de execução da pena privativa de liberdade.

O principal aspecto a ser tratado na abordagem do tema serão as implicações decorrentes do fim da obrigatoriedade do exame criminológico na análise do mérito do condenado na ocasião da progressão para um regime prisional mais brando. Após as modificações instituídas pela Lei 10.792/2003, a nova redação do $§ 1^{\circ}$ do artigo 112 da Lei de

\footnotetext{
${ }^{1}$ Adotaremos a expressão "Direito da Execução Penal" para designar o ramo do Direito Público que cuida das regras e institutos que regulamentam a execução da pena privativa de liberdade, cujos princípios e conceito serão delimitados no item 1.2 do presente trabalho.
} 
Execução Penal abandonou a referência expressa ao vocábulo "mérito", resumindo o requisito subjetivo do condenado ao "bom comportamento" atestado pelo Diretor do estabelecimento penitenciário onde for cumprida a reprimenda.

No entanto, boa parte da doutrina e da jurisprudência não aceita essa solução de interpretar isoladamente o artigo 112 da Lei de Execução Penal. Para essa corrente, a correta hermenêutica do Direito brasileiro consiste em se fazer uma interpretação sistemática dos diversos dispositivos legais que regulamentam a matéria. Desse modo, recomendam a realização de perícias para melhor avaliar os aspectos subjetivos do condenado na passagem para um regime mais brando de execução nos casos de maior gravidade.

Nesse panorama, o exame criminológico ainda é o principal meio disponibilizado ao juízo da execução quando se faz necessária uma avaliação mais criteriosa sobre os aspectos referentes à personalidade e periculosidade do condenado em casos concretos cujas peculiaridades exigem um pouco mais de cautela do magistrado na concessão de benefícios legais.

Isso quer dizer que, na prática, encontramo-nos diante de um problema básico sobre a maneira de avaliar os requisitos de natureza subjetiva para a progressão de regime prisional. Precisamos responder se o ordenamento jurídico brasileiro ainda admite impor ao condenado que ele se submeta a estas perícias criminológicas, ou se, por outro lado, a imposição de qualquer exigência além das previstas no artigo 112 da Lei de Execução Penal é inadmissível e constitui uma forma de constrangimento ilegal ao condenado, que passa a ter direito subjetivo á progressão ao cumprir os requisitos elencados no referido artigo.

As modificações operadas pela Lei 10.792/2003 geraram uma espécie de paradoxo no sistema de execução instituído pela Reforma Penal de 1984. Segundo o item 29 da exposição de motivos da Lei de Execução Penal (In: RANGEL, 1983, p. 68-69), o motor de todo o sistema progressivo é o merecimento do apenado. Nesse sistema, para progredir de um regime de execução mais rígido para outro mais brando, o condenado deve demonstrar durante a execução da pena que esta procurando melhorar sua condição pessoal com vias de um dia poder retornar ao convívio social em liberdade. Dessa maneira, uma corrente doutrinária entende que o requisito subjetivo do apenado não se limita à aferição do "bom comportamento" penitenciário apresentado durante o período de execução da pena, uma vez 
que ainda estão em vigor outros dispositivos legais que prevêem a avaliação do mérito, como o $§ 2^{\circ}$ do art. 33 do Código Penal.

Diariamente, a imprensa tem noticiado diversos casos onde condenados beneficiados com a progressão de regime concedida com base nos critérios atualmente vigentes, mas que demonstram não possuir a menor condição pessoal para cumprir o restante da pena em um regime com menores restrições a sua liberdade. Como exemplo, destacamos uma reportagem, veiculada no programa "Fantástico" de 05 de dezembro de 2010 e em outros telejornais da Rede Globo de televisão, na qual os jornalistas fazem o acompanhamento de diversos internos em regime semiaberto em vários estados do país. A matéria mostra exemplos de condenados que se aproveitam das benesses do regime semiaberto para frustrar os objetivos da execução penal. Estes condenados simplesmente não aparecem nos locais de trabalho indicados e ainda aproveitam o tempo em que estão fora do estabelecimento penitenciário para voltarem a delinquir. Essa situação demonstra a precariedade do atual sistema de avaliação das condições pessoais do interno na concessão de benefícios legais e a falta de estrutura do poder público para manter uma fiscalização efetiva sobre tais internos.

Através de exemplos como estes, podemos indicar que o sistema vigente não esta sendo adequado para os fins que se propõe e apontamos para a necessidade de se propor um modelo mais criterioso para a concessão desse tipo de beneficio. Principalmente em alguns casos mais complexos, é temerário que autores de crimes graves (crimes hediondos, crimes cometidos com violência ou grave ameaça à pessoa e crimes sexuais) e condenados com várias reincidências possam ser recolocados em convívio social sem a aferição das suas reais condições pessoais para tal.

No presente trabalho fazemos uma abordagem do modelo de execução penal e de suas particularidades referentes à progressão de regime prisional ao longo do período republicano brasileiro. Consideramos essa uma boa maneira de melhor compreender o problema por nós apresentado e assim tentar propor sugestões para sua solução.

Iniciamos nossa abordagem fazendo uma síntese temática dos institutos do Direito da Execução Penal necessários à compreensão do assunto a ser tratado no restante do trabalho. Desse modo, no primeiro capítulo do trabalho tratamos da concepção da pena privativa de liberdade, adiantando que toda exposição será baseada na concepção mista da 
pena, adotada pela Reforma Penal brasileira de 1984 e que se harmoniza com os preceitos da Defesa Social. Nesse capitulo delimitamos o "Direito da Execução Penal" e tratamos brevemente de seus princípios informadores, dentre os quais destacamos os princípios da reserva legal, da personalidade e da individualização da pena. Falaremos também da execução cientifica da pena, de sua individualização e das origens e características da classificação dos condenados. Discorremos a respeito da evolução histórica da execução penal e do surgimento dos diversos modelos de execução, dentre os quais daremos destaque ao sistema progressivo. Para finalizar o capitulo, trataremos da evolução do condenado durante a execução, da avaliação de sua personalidade e ainda abordaremos o conceito de "mérito" no andamento dos regimes prisionais.

No segundo capítulo do trabalho fazemos um histórico da implantação do sistema progressivo de execução penal no país, destacando em nossa abordagem os aspectos referentes à evolução dos critérios de ingresso e transferência do interno nos diversos regimes prisionais. Iniciamos o presente capitulo comentando os projetos apresentados respectivamente em 1933, 1957, 1963, 1970 e que tinham por objetivo a instituição de uma codificação nacional unificada para o Direito da Execução Penal. Entretanto, havia no Brasil uma resistência em se admitir uma regulamentação nacional autônoma para o Direito da Execução Penal durante a maior parte do século passado (DOTTI, 2009), assim estes projetos não lograram êxito em se converter em lei. Os institutos referentes à execução penal eram então regulamentados no Código Penal, no Código de Processo Penal e em leis extravagantes. Nesse capitulo também destacamos o tratamento dispensado por estes dispositivos legais aos institutos referentes aos regimes de execução da pena e aos critérios para a progressão e regressão nos regimes.

No capítulo seguinte passamos a tratar especificamente da Reforma Penal de 1984. Com a edição da Lei 7210, em 11 de julho de 1984, o Direito brasileiro finalmente passou a ter uma lei específica para regulamentar a execução penal no Brasil. Neste capitulo, discorremos a respeito as modalidades de pena privativas de liberdade instituídas (reclusão e detenção), os diferentes regimes de execução da pena (fechado, semiaberto e aberto). Também falaremos a respeito da execução progressiva da pena, do conceito de mérito e trataremos da avaliação dos aspectos subjetivos do condenado nos casos de progressão 
No próximo capítulo cuidamos das especificidades das avaliações técnicas realizadas com objetivo de subsidiar a individualização executiva e os pedidos de progressão de regime, previstas originalmente na Lei de Execução Penal. Tratamos das diferenças existentes entres o Exame de Personalidade, o Exame Criminológico e o parecer da Comissão Técnica de Classificação. Nesse capitulo abordamos detalhadamente o exame criminológico, tratando de conceituá-lo, definir sua natureza jurídica, e apresentar suas finalidades, objetivos, e conteúdo. Ainda apresentamos a origem histórica do exame, as diferenças entre o exame criminológico de entrada, realizado no inicio da execução da pena para a individualização e classificação do condenado, e o exame realizado para instruir os pedidos de progressão de regime prisional. Por fim, apresentamos uma pequena crítica aos problemas e limites do exame criminológico levantados na literatura.

No quinto capítulo, passamos a analisar as modificações introduzidas na execução penal pela Lei 10.792/2003. Inicialmente, indicaremos as alterações legislativas operadas pela lei nos institutos que regulam os critérios para a progressão de regime para depois abordarmos como tem sido tratada a questão da avaliação do mérito do condenado na progressão dos regimes prisionais após a vigência dessas alterações. Neste capitulo analisamos os dois posicionamentos que surgiram na doutrina e jurisprudência a respeito da possibilidade ou não da realização do exame criminológico com fins de subsidiar o juiz no instante da decisão a respeito da concessão ou negação do pedido de progressão para um regime prisional mais brando. Neste ponto apresentaremos os principais argumentos dos autores que defendem ou criticam a realização do exame criminológico de acordo com os preceitos da Lei de Execução Penal, do Código Penal e da Constituição Federal. Por fim, passamos a analisar como a jurisprudência do Supremo Tribunal Federal e do Superior Tribunal de Justiça têm se posicionado acerca do assunto desde então.

No último capítulo fazemos uma critica a respeito das mudanças introduzidas pela Lei 10.792/2003. Aqui, destacamos os motivos que levaram a Reforma Penal de 1984 a adotar o exame criminológico como o principal instrumento de avaliação subjetiva do apenado e observar porque o legislador de 2003 resolveu acabar com a obrigatoriedade do exame na concessão de benefícios legais. Neste capitulo procuramos discutir os principais aspectos abordados pela doutrina e também a pacificação da jurisprudência sobre o assunto após a aprovação da Sumula Vinculante 26 do STF e da Súmula 439 do STJ. Ainda abordamos as propostas de reforma desse ponto da legislação em tramitação no congresso nacional, para então tecermos nosso ponto de vista sobre o tema. 


\section{SÍNTESE TEMÁTICA E ANTECEDENTES HISTÓRICOS}

\subsection{A pena privativa de liberdade e as escolas penais}

Iniciamos nossa explanação tratando brevemente da concepção da pena privativa de liberdade diante das escolas penais tradicionais. Assim, dentre as teorias relativas, iremos destacar as concepções da Escola Clássica e da Escola Positiva italiana.

Álvaro Mayrink da Costa (1990, p. 45) observa que as diversas concepções filosóficas para a pena costumam a ser divididas em dois grandes grupos: teorias absolutas ou teorias relativas. Ele observa que há autores que ainda consideram uma terceira classe, a das teorias mistas ou ecléticas, porém considera que "este terceiro grupo não encontra suporte básico, uma vez que não se distinguem fundamentalmente das relativas.” Ele afirma que as teorias penais absolutas são as que "consideram a pena consequência necessária do delito, entendendo que nenhum bem ou fim social se procura atingir com a sua aplicação" (COSTA, 1999, p. 45-46) e que "as teorias penais relativas justificam a pena pelo bem a que se visa atingir"; nesta concepção a pena é um "meio para atingir um fim, um bem coletivo ou individual, que é intrínseco" (COSTA, 1999, p. 47).

Heleno Claudio Fragoso (1980, p. 5) observa que “os juristas clássicos, partindo de rígido enquadramento do magistério punitivo no plano ético, explicavam que a pena é essencialmente retributiva, e que representa o justo castigo pelo malefício praticado". Fragoso salienta que para essa escola, "a retribuição devia ser entendida como essência da pena, como sua maneira de ser, pois necessariamente ela constitui perda de bens jurídicos imposta pela realização do delito (por seu turno lesão de bens jurídicos). Álvaro Mayrink da Costa (1994, p. 49) salienta que, a pena privativa de liberdade na concepção da Escola Clássica "encerra um conceito de ordem moral, a retribuição do estado ao autor do ato punível pelo mal causado voluntaria e conscientemente à sociedade, sendo absolutamente determinada e existindo uma proporcionalidade qualitativa e quantitativa”. Nessa concepção a pena não possui fins de regenerar, intimidar, ou de defesa da sociedade, apenas possui finalidade de "desagravar a justiça, a divindade ferida." 
José Eduardo Goulart (1994, p. 25-26) considera que a Escola Positivista “traz notável inovação em relação ao conceito e ao fim da pena, passando a considerá-la exclusivamente como medida da defesa social, objetivando a recuperação do criminoso, ou então, sua neutralização, quando irrecuperável”. Para Heleno Claudio Fragoso (1980, p. 5), a pena, enquanto medida de defesa social, constitui um meio de defender a sociedade juridicamente organizada dos riscos e perigos da delinquência. Ele afirma que, ao cominar a pena em abstrato, o Direito Penal procura infundir o temor da punição e assim e inibir da prática do delito.

Álvaro Mayrink da Costa (1999, p. 49) salienta que a Escola Positiva "não vê na pena uma retribuição, mas sim uma prevenção, não tendo conteúdo do sofrimento, servindo diretamente à reeducação e à readaptação do delinquente na vida social”. Assim, esta escola não considera que a pena seja concebida como "um mal que o ordenamento jurídico imporia a quem viola a norma primária, por que o seu fim é a ressocialização do inadaptado e sua função é de meio de defesa social". Heleno Fragoso (1980, p. 5) ainda observa que, no momento da execução penal, "essa defesa opera através do impedimento físico do condenado (colocando-o na impossibilidade de praticar novos crimes) ou através do impedimento psíquico, seja pela intimidação, seja pela correção ou emenda".

O Direito brasileiro adota a concepção mista de pena, segundo a qual a pena procura compatibilizar o escopo retributivo da Escola Clássica com o ideal de defesa social da Escola Positiva. Nesta concepção a pena tem por finalidades: a preservação de bens jurídicos; a defesa social; a recuperação e ressocialização do condenado com vias de reinserção social; e também a punição retributiva do mal causado (prevenção especial) e a prevenção da prática de novas infrações (prevenção geral) (KUEHNE, 1995, p. 18). Em conformidade com esta concepção, a pena está fundamentada na retribuição; na prevenção (geral especial) e na defesa social (através de diferentes mecanismos, tais como segregação, mas com propósito de ressocialização ou integração).

José Eduardo Goulart (1994, p. 16) observa que o fundamento será diverso em função do momento em que a pena pode ser visualizada. Ou seja, a pena possui fundamentos, limites e funções distintas nas fases de cominação, aplicação e execução. 
Para ele, a pena tem como fundamento no momento de cominação legislativa o poder punitivo do estado e deve respeitar os limites impostos a este poder punitivo. Na cominação, a pena deve observar o principio da intervenção mínima do estado, segundo o qual "o direito de reprimir atos que ameacem ou ponham em perigo o convívio social [...] obriga a redução da intervenção estatal à necessidade da defesa de bens jurídicos" (GOULART, 1994, p. 16). Já em respeito ao princípio da proporcionalidade, a pena cominada deve ser compatível com a gravidade do fato típico, assim o estado não pode punir fatos de pequena relevância com longas penas. Por fim, o princípio da culpabilidade considera a existência de dolo ou culpa do agente um pressuposto necessário para aplicação da pena cominada (GOULART, 1994, p. 16-17).

No segundo momento, o fundamento para aplicação da pena é pratica da conduta delituosa. Nessa ocasião, o magistrado também deve observar os três princípios que já limitaram legislador na cominação da pena. Dessa maneira, ao definir a pena na sentença condenatória, o juiz deve observar a gravidade do fato praticado, a culpabilidade do transgressor e ainda deve considerar sua personalidade. (GOULART, 1994, p. 17)

A sentença condenatória é o fundamento da execução da pena, que aqui tem o fim de ressocializar o condenado visando reinseri-lo na sociedade. Nesta fase a pena deve guardar os limites da sentença e deve respeitar os direitos do condenado não atingidos por ela. (GOULART, 1994, p. 17-18)

Para Álvaro Mayrink da Costa (1994, p. 55) o fim da pena deve ter como patamar a humanização. Ele afirma que a função da pena no plano realístico é punir o autor do ilícito penal, mas também observa que a pena também o objetivo de fazer como que o apenado, "no período de permanência coativa na microssociedade prisional, reflita sobre si próprio e mude o estilo de vida para aceitar e, se aceito, quando da reinserção nos padrões vigentes da nossa macrossociedade". O autor ainda considera que:

"A finalidade e a justificativa das penas e das medidas associadas com a privação da liberdade visam a proteção da sociedade contra o crime. Mas essa meta só será alcançada quando, dentro do possível, se procura assegurar, durante o período de privação da liberdade, que o preso não tenha apenas a vontade, mas igualmente a capacidade de viver vida autônoma e ordeira, ao reingressar na sociedade" (COSTA, 1994, p. 205/206) 
Definidos os limites, funções e finalidades da pena (dentro da concepção adotada pelo Direito brasileiro) passamos a tratar da delimitação do Direito da Execução Penal.

\subsection{O Direito da Execução Penal: conceito, autonomia e princípios informadores}

No presente trabalho adotaremos a expressão "Direito da Execução Penal" para designar "o conjunto de normas jurídicas que tem por objetivo garantir e regular a execução de todas as penas, de seus substitutivos, dos dentes de execução e das medidas de segurança" (GOULART, 1994, p. 54-55). Segundo José Eduardo Goulart, o conjunto de comandos e princípios jurídicos do Direito da Execução Penal tem por objetivo regular a execução das penas de modo que ela seja realizada de acordo com os limites fixados na lei e na sentença condenatória, garantir que sejam respeitados todos os direitos do apenado não atingidos pela condenação, e ainda regulamentar a forma e as circunstâncias do cumprimento de todas as penas, de seus substitutivos e dos incidentes do processo executório através dos institutos que lhe são peculiares.

Em nossa concepção, rejeitamos a visão de que o Direito da Execução Penal possa ser concebido exclusivamente como um ramo do Direito Administrativo. Consideramos mais adequada a concepção José Eduardo Goulart (1994, p. 65), de que a matéria relativa aos institutos da execução penal "é regulada à luz de diversos ramos do ordenamento jurídico, posto que a defesa social, a garantia dos direitos e interesses do condenado e outros valores são amparados por normas constitucionais, penais, processuais, civis, administrativas".

Precisamos então definir os princípios informadores do Direito da Execução Penal, observando seu âmbito de aplicação e os seus respectivos limites. Segundo José Eduardo Goulart (1994, p. 86), no tema da matéria penal executória, estes princípios "assumem natural relevância", [...] e "observada sua fisionomia própria, atuam no sentido de iluminar suas bases ou fundamentos e, por igual, orientam sua aplicação e o sentido de sua compreensão".

Dentre os princípios informadores do Direito da Execução Penal iremos destacar: o princípio da reserva legal, o princípio da personalidade, o princípio da 
individualização da pena, o princípio da isonomia, o principio da proporcionalidade e princípio da humanização da pena.

O princípio da reserva legal constitui um dos pilares básicos do Direito Penal moderno no Estado Democrático de Direito. Renê Ariel Dotti (1982, p. 603) observa que na execução penal o princípio da reserva legal não pode se limitar à proclamação da reserva dos direitos do condenado não atingidos pela sentença, deve ter uma maior amplitude e "projetar-se em todos os quadrantes que durante séculos estão abrindo margem ao exercício autoritário do poder administrativo".

Desse modo, José Eduardo Goulart (1994, p. 91-92) considera obrigatório que a execução "se efetive em um regime de efetivas garantias ao interesse comunitário e aos direitos individuais. Para que isto se dê é imprescindível a vinculação da execução penal à Lei e ao Direito, enquanto aspecto essencial do caráter do Estado de Direito". O autor observa que o principio da reserva legal deve atuar "no sentido de conferir-lhe dignidade e estabilidade, proporcionando-lhe, pois, a indispensável funcionalidade, possibilitando que a execução da pena se desenvolva de forma orientada" (Goulart, 1994, p. 95).

Em sintonia com o Direito Penal da Culpa e em respeito ao princípio da personalidade, Jose Eduardo Goulart (1994, p.95) considera que a culpa do agente é o fundamento da medida da pena imposta e atua como limitador desta. Estabelecidos assim o limite e a justificativa da pena, constata-se que "ela dirige-se à pessoa do condenado, não podendo ultrapassá-la e operando em função da culpabilidade daquele, enquanto indivíduo responsável capaz por suas ações"(GOULART, 1994, p. 96)

Nessa concepção, o princípio da individualização da pena é consequência direta do postulado da personalidade (GOULART, 1994, p. 97). O princípio da individualização da pena reflete um conceito de justiça e não é uma antinomia ao princípio da igualdade. José Eduardo Goulart (1994, p. 106-107) salienta que "justiça, no âmbito do direito penal, significa também tratar-se o homem segundo os critérios individuais de sua personalidade". Desse modo, a pena deverá ser individualizada tanto no momento de sua aplicação como no momento de sua execução. 
Então observamos que no Direito da Execução Penal, em respeito ao princípio da isonomia devemos garantir o respeito à igualdade de direitos entre os condenados. Tal igualdade é entendida por José Eduardo Goulart (1994, p. 107) como "a proibição de distinções no gozo de direitos, sobretudo por motivos raciais, sociais ou políticos".

No Direito da Execução Penal, o princípio da proporcionalidade ${ }^{2}$ também é decorrente do princípio da personalidade da pena. Segundo José Eduardo Goulart (1994, p. 108), em respeito ao caráter retributivo da pena, ela deve "ser estritamente proporcional ao comportamento anterior do agente. Retirado da pena seu conteúdo de proporcionalidade, esvazia-se seu sentido de justiça, removendo-se a base ética do direito penal e negando-se ao acusado qualquer garantia substancial de liberdade".

José Eduardo Goulart (1994, p. 83) também observa que o Direito da Execução Penal “é uma das vias de efetivação dos direitos humanos, inalienáveis, por se fundarem na própria natureza do homem e que nenhum homem pode perder". Em respeito ao princípio da humanidade, não podemos admitir na execução penal punições cruéis, desumanas e degradantes. O autor salienta que essas modalidades de pena são incompatíveis com a dignidade da pessoa humana, "constituindo-se em modalidades de castigos, que repudiam ao senso moral da comunidade democrática, pois, ofendem a dignidade que sempre permanece em maior ou menor escala, até no pior delinquente" (GOULART, 1994, p. 110)

Definidos assim os limites e princípios que norteiam o Direito da Execução Penal, passamos a tratar da execução cientifica e da individualização da pena.

\subsection{Execução científica, individualização da pena e classificação dos condenados}

Conforme observamos na seção anterior, o Direito da Execução Penal encontra-se em harmonia com os princípios da humanidade e individualização da pena. Álvaro Mayrink da Costa (1994, p. XIV) observa a importância adquirida pela classificação

\footnotetext{
${ }^{2} \mathrm{Na}$ concepção de Robert Alexy (Apud: KÖHN, 2006), o princípio da proporcionalidade é utilizado para pacificar a colisão de princípios no caso concreto. Como não existe prevalência absoluta de um princípio frente a outro, devemos ponderar e avaliar no caso concreto qual princípio deve ser observado de modo a melhor atender os ideais de justiça, paz social e bem comum característicos do Direito da Execução Penal.
} 
cientifica (e não meramente legal) do condenado no processo de individualização na execução da pena. Para ele, "a individualização moderna consiste em estabelecer um processo de ressocialização, uma vez que a questão não se limita à repressão ou à prevenção da criminalidade" (COSTA, 1994, p. XV). Nesta concepção, a execução penal tem por objetivo maior a reintegrar o apenado na comunidade social, buscando garantir que nesse processo não haverá intolerância da parte da própria comunidade ou a inadaptação do próprio apenado.

Álvaro Mayrink da Costa (1994, p. 54) aponta que a origem da individualização subjetiva ocorre efetivamente com início da avaliação da personalidade do agente no campo penal. Ele observa que a Escola Positiva italiana, a antropologia "lombrosiana" e, posteriormente, a União Internacional de Direito Penal tiveram forte influencia e criaram a base para que houvesse uma mais ampla individualização baseada na valoração do elemento pessoal nas legislações europeias do início do século passado (anteprojeto do Código Penal suíço de 1893 e 1903; Código Penal da Noruega de 1902; e anteprojetos alemão e austríaco de 1909). O autor afirma que a tese individualizadora ganhou força na doutrina no final do século XIX e inicio do século XX, cuja obra L'individualisation de La peine, de Saleilles, foi pioneira na condensação e esquematização do problema em 1909.

Nos dias atuais, a individualização da pena segue a concepção mista. Assim, ao apreciar do fato e determinar a pena, o juiz deverá simultaneamente analisar a natureza do delito e investigar a personalidade do delinquente. (COSTA, 1994, p. 54)

Sergio Pitombo (1999) observa que há dois gêneros de individualização penal: legislativa e judicial. Para ele, a individualização legislativa consiste na "adequação prévia de certa pena a determinada conduta típica”. Já a individualização judicial da pena ocorre em dois momentos complementares: na sentença, com a fixação do montante da pena, e durante o processo de execução desta pena. Esta primeira espécie, por ele denominada "sentencial" ou "cognitiva" é a que se dá no processo de conhecimento e possui natureza condenatória, enquanto que a segunda é denominada "executória" e será realizada continuamente durante todo período de execução da pena.

Para Sérgio Pitombo (1984), individualizar a execução da pena significa prover a cada apenado as oportunidades e os elementos necessários para possibilitar a sua reinserção social, 
observando sua individualidade enquanto pessoa, ser distinto. Por esse motivo, esta individualização deve "aflorar técnica e científica, nunca improvisada, começando na observação, que leva à classificação”. Para ele, a individualização da pena privativa de liberdade "consiste na justa adequação, ou medida, da pena a certo comportamento ilícito e típico; ainda, à pessoa do acusado; e, também, na conformidade do regime ao condenado" (PITOMBO, 1999). José Eduardo Goulart (1994, p. 102) ainda observa que a individualização executiva da pena é uma atividade integrada entre a autoridade jurisdicional e a administrativa.

No processo de individualização executiva é essencial o conhecimento integral do condenado. Assim, Álvaro Mayrink da Costa (1994, p. 205) salienta que devemos procurar conhecer o sentenciado logo na fase inicial da execução, para desde então lhe aplicar o tratamento penal adequado. O autor afirma que é durante o processo inicial de observação do apenado que começa a sua classificação. Ele também observa que as finalidades básicas da classificação são: "separar de seus companheiros os internos que, pela vida criminal pregressa, ou por seu caráter, possam exercer influência maléfica"; e "subdividir os presos em categorias que facilitem um tratamento especial, adequado à sua reinserção social" (COSTA, 1994, p. 206). O autor ainda observa que a classificação do interno deve ser feita imediatamente após seu recolhimento em um estabelecimento prisional e deve considerar sua personalidade, com a finalidade de elaborar um plano para seu tratamento, que possibilite o aproveitamento das capacidades apenado e que também possa considerar suas necessidades e inclinações.

Álvaro Mayrink da Costa (1994, p. 54) considera que, apesar de já ocorrer certo grau de individualização na adequação da pena ao grau de culpabilidade do autor por meio da valoração de elementos subjetivos (como exemplo temos as causas judiciais do artigo 59 do Código Penal), a individualização penal, "no sentido da adequação da pena privativa da liberdade à personalidade do delinquente", só realmente se efetiva com a definição do regime penal (fechado, semiaberto ou aberto) adequado a sua reeducação e reinserção no meio social. O autor ainda observa que o regime penal também constitui um "meio de proteção social contra os inadaptados".

Passamos então a tratar dos sistemas e dos regimes de execução da pena na seção seguinte. 


\subsection{Os regimes de execução penal, sistemas penais e a evolução do condenado no sistema progressivo}

O modelo de sistema penal adotado para a execução é de fundamental importância para definir o regime de execução da pena imposta ao condenado. Assim, para individualizá-la segundo os preceitos da execução cientificamente orientada faz-se necessário a adoção de um regime penitenciário compatível com a finalidade da pena.

Para Sérgio Pitombo (1984), a definição do regime penitenciário engloba todo o conjunto de princípios e regras de Direito Penal, Processual e Administrativo que regulamentam a execução da pena privativa de liberdade e que tem por objetivo "tornar efetiva a execução penal da sanção específica, bem como lhes dar reforma e emenda moral". Em sua concepção, o "regime de execução penal" pode ser definido como "o estado de cumprimento de pena, em que se coloca o condenado, no tocante à intensidade modulada de redução da liberdade.” (PITOMBO, 1984). Cézar Roberto Bitencourt (1998, p. 265) observa que "os regimes de cumprimento de pena direcionam-se para maior ou menor intensidade de restrição da liberdade do condenado, sempre produto de sentença penal condenatória”.

Álvaro Mayrink da Costa (1994, p. 273 a 276) discorre a respeito dos modelos de sistemas penais que surgiram no século XIX, aos quais ele denomina de "sistemas penitenciários clássicos”. A seguir passamos a descrever brevemente as características desses modelos de sistemas penitenciários.

O sistema pensilvânico, (também denominado de "regime da Filadélfia") foi criado na Eastern Penitentiary, em 1828. Baseava-se no isolamento celular e no trabalho no interior das celas. O diretor, os guardas, o capelão e os membros de sociedades de ajuda aos presos eram as únicas pessoas que podiam visitá-los. Os internos não podiam receber ou escrever cartas e a Bíblia a única leitura permitida a eles (COSTA, 1994, p. 273).

O sistema auburniano (também chamado de "sistema do silêncio") foi criado em 1816 em um estabelecimento penal de Nova York. O regime ali estabelecido consistia no isolamento celular noturno e no trabalho diurno coletivo, em silêncio, onde os condenados não podiam falar entre si, nem dirigir a palavra aos guardas. Neste sistema, havia 
ainda delinquentes mais velhos e mais perigosos que deveriam ficar em isolamento celular completo. (COSTA, 1994, p. 273-274)

O sistema progressivo foi criado em 1840, na ilha Norfolk, Austrália, e destinava à detenção de deportados forçados da Grã-Bretanha. Neste sistema ocorrem distintas etapas até a completa reintegração do indivíduo à sociedade. Tudo fica condicionado ao binômio conduta-trabalho. A pena imposta não tinha duração determinada e deveria ser cumprida em três períodos: a) período de prova (isolamento diurno e noturno e trabalho obrigatório - regime pensilvânico); b) trabalho em comum durante o dia e isolamento noturno (regime auburniano); c) liberdade condicional. Durante o segundo período, o apenado recebia "vales" que o condicionavam a passar a classe superior (eram quatro) e quando o mesmo atingisse a primeira (na verdade, a última) e tivesse permanecido um mínimo de tempo predeterminado, poderia então obter o "ticket of leave" (um tipo de liberdade condicional). (COSTA, 1994, p. 274)

O sistema progressivo introduzido nas prisões da Irlanda em 1854 difere do progressivo Inglês em dois pontos: nele os internos podiam conversar durante o trabalho diurno e também havia um período intermediário anterior ao livramento condicional, que consistia no trabalho externo com objetivo de preparar o detido para a futura vida livre (COSTA, 1994, p. 275). Esta fase seria análoga ao atual regime aberto.

Com a criação do sistema de Elmira, em 1876 no Estado de Nova York, a reação curativa contra a criminalidade se incorpora mais claramente na política penitenciária. O estabelecimento de Elmira consistia de uma casa de correção com assento sobre a educação dos apenados, onde ele entraria no estabelecimento não para pagar a sua pena, mas para melhorar enquanto ser humano. Neste sistema inaugurava-se o sistema unitário (pena e medida de segurança), a pena não possuía limite temporal e o internado somente era posto em liberdade quando encontrava um emprego satisfatório, mediante concessão do superintendente da instituição. (COSTA, 1994, p. 275)

O sistema progressivo é adotado atualmente pelo Brasil e por diversos países do mundo como Itália, Holanda, Suíça, França, Portugal, Finlândia, Dinamarca, Espanha, Argentina, etc. (COSTA, 1994, p. 276). Dentre as vantagens desse sistema podemos destacar a eliminação dos graves inconvenientes gerados pelo isolamento celular completo, a 
vedação da imposição da regra de silêncio do sistema auburniano e a execução da pena organizada através de fases e classes a serem vencidas pelo apenado. Na passagem de uma classe para a outra há uma redução gradativa do rigor do regime e das restrições à liberdade impostas e um acréscimo proporcional no convívio social do apenado.

\subsection{Avaliação dos apenados e o conceito de mérito}

Conforme apresentamos no item anterior, no sistema progressivo, também adotado no Brasil, "as penas privativas de liberdade só guardam cabência dotadas de movimento" e "os aludidos regimes, por sua vez, direcionam-se para a maior ou menor parcela de vida livre restringida pela decisão condenatória" (PITOMBO, 1984). Desse modo, a "sanção aplicada possibilita ao apenado progredir ou regredir nos regimes, ampliando ou diminuindo seu status libertatis" (BITENCOURT, 1998, p. 265).

No entanto, tal progressão não deve realizar-se de modo automático, mas sim de modo “alomático", conforme salienta Sérgio Pitombo (1984), e o que irá determinar o movimento será a demonstração de merecimento durante a execução da sentença. Assim, o "ponto propulsor de conquista ou de perda de maiores regalias no cumprimento da pena privativa de liberdade consiste no mérito ou demérito do condenado" (BITENCOURT, 1998, p. 265).

Para Rogério Lauria Tucci (1988, p. 272), o mérito do condenado traduz-se no seu merecimento, isto é, na "habilitação do condenado á progressão". Ele afirma que o mérito deve "ser aferido em razão dos respectivos valores intrínsecos, morais e laborais, que o façam merecer o correspondente resultado, tal como na lei estabelecido - uma verdadeira recompensa, enfim pelo seu comportamento prisional".

Para Sérgio Pitombo (1999) o "mérito, no andamento dos regimes prisionais, consiste, no juízo objetivo, que se ultima no processo de execução, do proceder do condenado; assim, valorando-o, em base de vários elementos, postos em relacionalidade, e ostentando em ato decisório motivado". Ele também afirma que "é mérito, em palavras simples, o valor positivo, ou negativo, que se atribui a certo comportamento, para sancioná$10 "$. 
Em sua concepção, "mérito" associa-se à ideia de sanção jurídica lato sensu. Assim, a sanção correspondente a um comportamento considerado negativo seria imposta na forma de um castigo, enquanto que, ao comportamento valorado como positivo seria imposto, sancionado, um prêmio, uma recompensa. Sérgio Pitombo (1999) observa que "a sanção, portanto, corresponde ao mérito, consoante ao valor que se dê à conduta do condenado. Merecer é agir de tal maneira que a obtenção do merecimento - castigo ou prêmio - tenha-se por justa."

Desse modo, o mérito do apenado, isto é, o valor positivo ou negativo atribuído à sua conduta durante a execução penal, será o principal fator de ordem subjetiva a ser considerado na determinação da intensidade da pena, ou seja, na definição do regime penal conforme o sistema progressivo instituído.

Tomando como ponto de partida o regime de execução inicial determinado na sentença condenatória, Pitombo (1999) indica que o mérito do condenado durante a execução "é que indicará se ele progride, regride, ou estaciona". No entanto, ele salienta que somente "o desmerecimento deve levar à regressão", e que "a simples falta de mérito conduz ao estancamento na situação ocupada", não cabendo progressão nem regressão.

Sobre este aspecto, Pitombo faz uma ressalva ao observar que o mérito absoluto constitui uma meta teórica, um limite intangível ${ }^{3}$. Assim, na aferição do mérito, devemos então avaliar as características e capacidade do condenado em se aproximar desse valor limite, uma vez que o homem nunca irá atingir o mérito ou demérito absoluto.

Nesse sentido, teremos três possibilidades para valorar o mérito. No Primeiro caso, o condenado apresenta "mérito positivo", pois demonstra aptidão e reúne condições de progredir, estando apto a cumprir o restante da pena em regime menos severo. No segundo caso, ele apresenta "demérito", ou "mérito negativo", quando demonstrar a incapacidade de

\footnotetext{
${ }^{3}$ Sérgio Pitombo (1999) observa que "Limite, dentre outros sentidos, é ponto que não se pode atingir, ou transpor. [...] A expressão conceito-limite, aqui, se utilizou para indicar tendência - esforço ou desejo maior ou menor. Assim, potência que não se atualiza, por inteiro, jamais. O pleno mérito e o completo demérito inexistem, seja o ser humano livre, ou prisioneiro. [...] O indispensável está em verificar se os elementos meritórios positivos excedem, ou não, eventuais faltas e omissões, para se admitir acesso a regime prisional mais brando. Observar, também, se o condenado preferiu não ostentar mérito, ou demérito; devendo, assim, restar onde se encontra. Sem cabida fazê-lo retrogradar."
} 
adequação ao regime atual, seja por comportamento incompatível ou por prática de faltas graves que determinem a sua regressão para cumprimento da pena em regime mais severo. No último caso, há a falta de mérito, ou seja, o condenado não demonstra possuir qualidades para progredir, mas também não apresenta condições incompatíveis com o regime atual, devendo permanecer estacionado neste regime, até apresentar mérito (positivo) para progredir ou demérito (mérito negativo) que recomende sua regressão.

Para José Eduardo Goulart (1994, p.79-80), o "mérito" do interno na execução significa a "sua adesão voluntária ao conjunto de regras e medidas que venham a possibilitar seu retomo ao convívio social". O Autor observa que este processo deve ser considerado ao longo de toda a via executória, aplicando-se não apenas nas promoções do regime fechado para o semiaberto, mas também nas progressões deste regime para o aberto.

Assim, precisamos definir os subsídios necessários para a avaliação do mérito. Historicamente, os meios científicos mais utilizados para se levantarem informações sobre os diversos componentes que devem ser considerados nesta avaliação tem sido a o processo de observação do apenado e o exame das características biológicas, psicológicas e sociais do autor do ato delituoso. No primeiro caso, as informações são levantadas no período de observação inicial e no segundo por meio da realização do exame criminológico. ${ }^{4}$

De acordo com Álvaro Mayrink da Costa (1994, p. 62) O exame criminológico tem por objetivos "a graduação da pena privativa da liberdade" e "a fixação de dados sobre a pressão, com a aplicação de medidas sancionadoras, de caráter preventivo, derivadas da periculosidade de agente (regime prisional)". Segundo o autor:

"A personalidade humana, observada do ângulo repressivo, é fator preponderante para a aplicação da pena e fixação do regime prisional e os dados investigados constituem um dos pontos de interseção, entre a regra perceptiva e o comando sancionador da norma penal. A incidência da sanctio iuris, sobre uma conduta típica, sofre a refração de quem delinquiu, pois o agente do crime terá a punição graduada também em razão dos traços que marcam a sua personalidade. (COSTA, 1994, p. 62)

\footnotetext{
${ }^{4}$ Não teceremos maiores comentários sobre este ponto neste momento, pois dedicaremos um capitulo exclusivo para tratar das avaliações técnicas dos encarcerados no qual discorreremos de maneira mais completa sobre os diversos aspectos do exame criminológico.
} 
Feitas essas considerações iniciais, passamos a tratar no capitulo seguinte da regulamentação dos diversos institutos que regularam o direito das execuções penais no Brasil durante o século passado até o advento da Reforma Penal de 1984. 


\section{OS ANTECEDENTES LEGISLATIVOS E A REGULAMENTAÇÃO DO DIREITO DA EXECUÇÃO PENAL NO BRASIL ANTES DA REFORMA DE 1984}

\subsection{As propostas de codificação para o Direito da Execução Penal}

Antes da instituição da Lei de Execução Penal pela reforma de 1984, tivemos no século passado quatro propostas de projetos para instituir uma regulamentação nacional para o Direito da Execução Penal: o anteprojeto de Código Penitenciário de 1933, de Cândido Mendes de Almeida, José Gabriel de Lemos Britto e Heitor Pereira Carrilho; o anteprojeto de Código Penitenciário de 1957, de Oscar Stevenson; o a anteprojeto do Código das Execuções Penais de 1963, de Roberto Lyra; e o anteprojeto de Código Penitenciário de 1970 de Benjamin Moraes Filho. Passamos a seguir a destacar brevemente os principais aspectos de cada um desses anteprojetos.

\subsubsection{O Projeto de Código Penitenciário de 1933}

Em 1933 surgia o primeiro projeto republicano para a edição de Código Penitenciário (In: ALENCAR, 1985, p. 175-287). A comissão responsável pelo anteprojeto foi composta pelos juristas Cândido Mendes de Almeida e José Gabriel de Lemos Britto e pelo médico psiquiatra Heitor Pereira Carrilho. Os autores do anteprojeto salientavam que o este código fora "redigido de modo a ser observado em todo o Brasil; e a efetividade da execução da pena criminal é assegurada pela actuação directa e permanente dos Conselhos Penitenciários [...] que exerceriam suas funções sob a fiscalização [...] das autoridades judiciárias" (GOULART, 1994, p. 65-66).

Este projeto foi pioneiro em prever a tripartição dos códigos em sede penal, possuía uma profunda orientação etiológica e positivista e também primava pela exaltação do saber médico no trato da questão penitenciária. (ROIG, 2005, p. 104), pois partia de “premissas positivistas e antropológicas no enfrentamento da questão penitenciária". (ROIG, 2005, p 111). 
O anteprojeto de 1933 também refletia o caráter retributivo da execução penal e de sua efetividade como forma de prevenção criminal. Isso se nota pela leitura de sua exposição de motivos, que prevê a criação de um cadastro nacional com os dados do sistema penitenciário de modo a prover dados para estudo da evolução da criminalidade nacional. (PITOMBO, 1996).

O ideal de defesa social também esta presente no projeto (ROIG, 2005, p. 104). O seu texto indica que "as penas detentivas serão cumpridas de modo a estimular a regeneração dos condenados, levando-se em consideração as suas condições individuais" (art. $9^{\circ}$ ) e à restrição de direitos dos apenados teria "não só com o objectivo de restaurar-lhes as energias physicas e moraes, como no de defesa da sociedade"(art. 587).

Rodrigo Roig (2005, p. 105-106) observa que outro aspecto a ser destacado anteprojeto de 1933 seria a "minuciosa organização antropológica, médica e psiquiátrica dos estabelecimentos penais". O projeto previa a criação dos "Institutos de Antropologia Penitenciária" com função de "examinar os reclusos dentro dos recursos experimentaes da technica psycho-anthopologica e medica e seus methodos auxiliares" (art. 59). Também indicava o estudo dos diversos fatores físicos e psíquicos delineiam a personalidade dos delinquentes: heredologia criminal, predisposição individual ao delito, genealogia dos reincidentes e o estudo da "temibilidade" dos criminosos (art. 60, $\S \S 1^{\circ}$ a $3^{\circ}$ ). Observa-se no projeto a orientação para a "individualização da terapêutica penal, em face dos resultados das investigações biotipológicas e médicas" (art. 60, §4º ), o relato do prognóstico de regeneração do condenado, com indicação da subsistência ou não do "estado perigoso" (art. $60, \S 6^{\circ}$ ) e a prolação de pareceres acerca dos elementos necessários à apreciação da personalidade dos mesmos $\left(\operatorname{art} .60, \S 8^{\circ}\right)$.

Rodrigo Roig (2005, p. 109) ainda atenta para a preocupação do projeto com "a investigação etiológica e uma intervenção utilitarista sobre os indivíduos tidos como desviantes". Observa que, neste contexto, os valores de "ordem, segurança, pesquisa e regeneração" direcionariam a atuação das autoridades responsáveis pela execução penal.

\subsubsection{Anteprojeto de Código Penitenciário de 1957}

No ano de 1957, Oscar Stevenson propôs novo anteprojeto para a edição de um "Código Penitenciário" brasileiro (In: ALENCAR, 1985, p. 289-336). O modelo proposto 
baseava-se na autonomia do direito penitenciário, era atrelado à ideologia do tratamento e também preocupava-se com o aspecto ressocializador da pena, com sua execução individualizada e com o respeito à dignidade da pessoa humana (PITOMBO, 1996).

José Eduardo Goulart (1994, p. 67) aponta como o principal aspecto deste anteprojeto “o reconhecimento explícito dos direitos dos presos, embora submetidos a condições, e objeto de enumeração não taxativa" (arts. 145 a 148). Rodrigo Roig (2005, p. 112-113) assevera que o projeto procurou contemplar os preceitos da reserva legal (art. 106) e da individualização judicial e executiva da pena (art. $5^{\circ}$ ), até então carentes de positivação no âmbito do direito penitenciário nacional.

De acordo com Rodrigo Roig (2005, p. 113), também é possível verificar no projeto de 1957 "uma índole teleológica mais humanizadora". Neste sentido, podemos encontrar em diversos trechos do projeto ${ }^{5}$ uma tentativa de se reduzir os efeitos negativos do encarceramento e o "repúdio ao caráter privatístico dos direitos dos reclusos". Sob esta ótica, os direitos dos reclusos não atingidos pela condenação "passariam a ser encarados como verdadeiros direitos públicos, subjetivos, individuais, de personalidade e civis." (ROIG, 2005, p. 113)

De acordo com o anteprojeto, o Conselho Disciplinar passaria ser o responsável pela caracterização das faltas, pela imposição das sanções disciplinares correspondentes e pela concessão de benefícios (art. 112 e seguintes), e em seu quadro haveria necessariamente um médico. (ROIG, 2005, p. 113-114).

Outro ponto do projeto de 1957 que reflete a manutenção da "essência positivista e etiológica" do projeto de 1933 seria a criação do "Serviço de Observação Preparatória" e do "Serviço de Recuperação". O primeiro teria função de examinar a personalidade dos presos provisórios (de modo a identificar as condições mentais, a motivação do fato imputado e a existência ou não de periculosidade) com vias de produzir um

\footnotetext{
${ }^{5}$ Como exemplo Rodrigo Roig (2005, p. 113) cita o item 31 da exposição de motivos ao projeto de 1957
} 
"laudo" para a instrução do processo criminal ${ }^{6}$ (art. 226, e item 45 da exposição de motivos) (ROIG, 2005, p. 114).

O "Serviço de Recuperação" (art. 47) seria o órgão responsável estudo da personalidade dos condenados e a classificação dos mesmos para a o tratamento penitenciário adequado durante a fase de execução. Neste estudo, a apreciação "anamnéstica" da personalidade do indivíduo (art. 53) seria realizada através da observação dos "aspectos clínico, morfológico, fisiológico e neuropsiquiátrico, passando pela análise de sua inteligência, sentimentos, instintos, tendências e aptidões, bem como de sua vida pregressa, formação religiosa e nível cultural (ROIG, 2005, p.114)

\subsubsection{Anteprojeto do Código das Execuções Penais de 1963}

Sob o influxo das medidas de reforma no Governo João Goulart, em 1963, o professor Roberto Lyra apresentou anteprojeto para regulamentação da execução penal denominou por ele "Código das Execuções Penais" (In: ALENCAR, 1985, p. 337-409).

Roberto Lyra recusava a denominação "Código Penitenciário", salientava que seu projeto preocupava-se mais com o condenado após o cumprimento da pena e ainda esperava que o anteprojeto pudesse alavancar o estabelecimento de uma nova política criminal no Brasil. (PITOMBO 1996).

$\mathrm{O}$ anteprojeto demonstrava a preocupação de garantir obrigatoriamente a jurisdicionalização das diversas fases do processo de execução penal, pregando a criação de um juízo especifico para este fim (art. 18) (PITOMBO 1996). Roberto Lyra (1978, p. 212) defendia que esse Juiz deveria conduzir o processo de execução para compatibilizar a garantia da ordem social com o respeito aos preceitos da humanidade, reserva legal e responsabilidade, "sendo incompreensível a ausência do juiz no único momento real e concreto da jurisdição."

Rodrigo Roig (2005, p. 118-119) salienta que o projeto de 1963 não abandonava o modelo criminológico/etiológico, mas modificava o enfoque principal, que passava a considerar à influencia das condições sociais e de vida a que são submetidos os

\footnotetext{
${ }^{6}$ Discutiremos mais à frente os aspectos controversos a respeito da realização do exame criminológico durante a fase de instrução criminal frente ao princípio da presunção de inocência
} 
criminosos associadas às características biológicas destes indivíduos (art. 16). Tal mudança refletia as alterações no paradigma criminológico da época, onde o delinquente passava a ser visto "não mais pelo prisma estritamente subjetivo - periculosidade do indivíduo -, mas agora também pela ótica do ambiente em que se vê inserido - perigosidade do meio social". Segundo Roberto Lyra (1978, p. 233) “o projeto não poderia estimular o exame da personalidade do criminoso e das causas da criminalidade sem o exame do meio social de onde vem e para onde voltará o delinqüente e onde ondulam, às vezes tempestuosamente, as forças etiológicas."

No campo disciplinar, a proposta de Roberto Lyra previa que apenas as infrações disciplinares graves e suas respectivas sanções seriam definidas pelo "Regulamento Federal das Execuções Penais" do Poder Executivo (art. 245). A definição das demais espécies de infrações e sanções disciplinares de menor gravidade seria objeto de regulamentação estadual (art. 49). O projeto ainda vedava o cancelamento administrativo de infrações disciplinares (art. 57). Tal vedação teria o intuito de não negar ao juiz o conhecimento dos elementos necessários para verificação do mérito na concessão dos benefícios. (ROIG, 2005, p. 119)

Destacamos que os anteprojetos de 1957 e 1963, de Oscar Stevenson e Roberto Lyra respectivamente, não chegaram sequer à fase de revisão, uma vez que, naqueles momentos históricos, era questionável a "constitucionalidade da iniciativa da União para legislar sobre as regras jurídicas fundamentais do regime penitenciário, de molde a instituir no País uma política penal executiva." (item 3, da exposição de motivos da LEP, in: RANGEL, 1983, p. 67)

\subsubsection{Anteprojeto de Código Penitenciário de 1970}

Em 1970, Benjamin Moraes Filho apresentou novo anteprojeto de "Código de Execuções Penais", cuja comissão revisora era composta pelos juristas José Frederico Marques, José Salgado Martins e José Carlos Moreira Alves. (In: ALENCAR, 1985, p. 410459)

José Eduardo Goulart (1994, p. 69-70) observa que o anteprojeto buscava harmonizar seus preceitos aos dos demais códigos que iriam entrar em vigor. Ele anota que, conforme exposição de motivos, a finalidade da execução penal seguia preceito estabelecido pelo artigo 
37 do Código Penal de 1969, de que "A pena de reclusão e a de detenção [...] devem ser executadas de modo que exerçam sobre o condenado uma individualizada ação educativa no sentido de sua recuperação social”. Rodrigo Roig (2005, p. 120) observa que o projeto também pretendia abordar "questões essenciais de natureza processual e administrativa, sempre tendo em conta a necessidade de conciliação entre os escopos de retribuição e defesa social". Sérgio Pitombo (1996) afirma que o projeto, ao indicar que "o tratamento penal tem por finalidade a preparação do sentenciado preso para a vida em liberdade e será efetivado por meio da assistência, da educação, do trabalho e da disciplina", estava permeado pela "ideologia do tratamento".

Na sua estruturação, o anteprojeto de 1970 buscava um meio-termo entre o casuísmo exagerado do projeto de 1933 e o aspecto generalista do projeto de 1963. (ROIG, 2005, p. 120). Assim, conferia aos Estados poder para legislar supletivamente e elaborar regulamentos regionais para a execução penal (art. 233). Sob esta orientação, o projeto arrolou "os diversos tipos de sanção disciplinar, bem como a forma de sua aplicação, no intuito de federalizar o poder de regulamentação punitiva", mas deixou a cargo dos regulamentos estaduais a tarefa de detalhar as faltas disciplinares em espécie. (ROIG, 2005, p. 123)

Com referencia à intervenção judicial no processo de execução, Rodrigo Roig (2005, p. 120) assevera que o anteprojeto “optou por firmar um critério eclético”. Nesse modelo, caberiam ao Juiz primordialmente os atos de supervisão e certos atos decisórios e seriam atribuídos à autoridade administrativa os poderes de execução das normas e da aplicação do tratamento penal (art. $\left.9^{\circ}\right)$.

O item 14 da exposição de motivos do anteprojeto indicava a realização do "exame de classificação" com vistas à individualização do tratamento penal, estudo da personalidade e lotação adequada do sentenciado. O "exame de classificação" (art. 41) abrangeria a avaliação médica-psiquiátrica, o levantamento da situação sócio-familiar, a verificação do grau de instrução e de aptidão profissional e a aferição do "nível ético" e do “grau de inadaptação social” do condenado (ROIG, 2005, p. 120)

O sistema progressivo proposto pelo anteprojeto (art. 147) seguia o modelo clássico, composto de três fases: classificação, tratamento e livramento condicional. A 
anamnese classificatória teria duração máxima de meses e indicaria o estágio de tratamento orientação, adaptação ou semi-liberdade - adequado ao processo terapêutico de "regeneração" do condenado. Observamos que a fase de tratamento não estaria vinculada ao cumprimento de um lapso temporal de pena, adotando critério baseado no "índice de aproveitamento do apenado" (art. 149, parágrafo único), e este era aferido através do "índice ético", do "grau de sociabilidade" e da "conduta na vida prisional", assentados em seu "Boletim Penal" (art. 48) (ROIG, 2005, p. 122).

De acordo com o exposto até agora, podemos observar que as diversas propostas de codificação para a execução penal apresentadas no século passado "refletem, de forma cristalina, as distintas orientações criminológicas de seus autores e de seu tempo" (ROIG, 2005, p. 103). Apesar delas não terem se convertido em diplomas legais concretos e postas efetivamente em prática, não podemos deixar de destacar a grande importância que tiveram para delinear "muitos dos contornos da atual legislação penal executiva brasileira".

Feita esta observação, passamos então a apresentar a regulamentação dos institutos da execução das penas privativas de liberdade no direito brasileiro durante o século passado.

\subsection{A regulamentação da execução penal brasileira no período republicano}

Neste tópico traçaremos um breve panorama acerca da evolução do tratamento dispensado pelo ordenamento jurídico brasileiro aos institutos da execução penal (em especial aos relativos à progressão de regime prisional) no período republicano até a edição da Lei de Execução Penal, em 1984.

Até o advento do projeto que se converteu na Lei de Execução Penal, as diversas propostas de criação de uma regulamentação nacional autônoma para o direito de Execução Penal não foram além do protocolo de chegada no Congresso Nacional, uma vez que vingava a superstição de que a execução das penas e medidas de segurança não poderia ser objeto de regulamentação por meio de uma lei federal (DOTTI, 2009). 
Desse modo, a matéria era tratada de forma esparsa pelas leis penais e processuais penais. Passamos então a apresentar os pontos que regulamentavam a execução penal até a Reforma Penal de 1984, nos atendo especialmente aos dispositivos relativos aos tipos de penas, regimes de execução e regras para progressão de regime.

O Código Penal de 1890 (Decreto 774 de 20 de novembro de 1890) prescrevia as penas de prisão celular (isolamento celular com obrigação ao trabalho e cumprida em estabelecimento especial), reclusão (executada em fortalezas militares), prisão com trabalho obrigatório (destinada aos vadios e cumprida em penitenciárias agrícolas) e de Prisão Disciplinar (para os menores até 21 anos, cumpridas em estabelecimentos industriais especiais). (DOTTI, 1998, p. 55-56) O artigo 53 deste decreto previa que os condenados deveriam ter trabalho adequado às habilidades e ocupações anteriores, já refletindo preocupação de individualização na execução da pena de prisão.

Em 1927, o desembargador Virgílio de Sá Pereira apresentava projeto de reforma para o Código Penal (DOTTI, 1998, p. 60-62). O projeto previa a classificação dos delinquentes (de acordo com a periculosidade criminal e social) e a individualização da pena, refletindo a influencia da escola positiva de humanização da execução.

O artigo 113 da Constituição Federal promulgada em 16 de julho de 1934 afirmava a necessidade de garantir o respeito aos princípios fundamentais de segurança individual e coletivos como a irretroatividade da lei mais gravosa (item 27) e a personalidade da pena (item 28).

Com o golpe de estado em 10 de novembro de 1937 e a outorga da Carta Política, o Estado Novo afirmou a necessidade de edição de um Código Penal em sintonia com a nova ordem social instituída. Em 1938, foi apresentado o anteprojeto de reforma elaborado pelo professor Alcântara Machado que resultou na edição do Código Penal de 1940 (Decreto Lei 2.848 de 07/12/1940) (DOTTI, 1998, p. 68-70). O projeto pregava autonomia entre os momentos de aplicação e de execução das penas, assim as regras da execução seriam definidas em um "Código Penitenciário". No entanto, não houve edição de um "Código Penitenciário" e o Código Penal de 1940 limitou-se nos artigos 30 e 31 a estabelecer diferenças para execução das penas de reclusão e de detenção. 
A pena a mais rigorosa era a de reclusão que deveria ser cumprida preferencialmente em uma penitenciária e que também sujeitava o condenado a trabalho remunerado e a repouso noturno. Seu cumprimento era realizado em quatro fases: 1) período de isolamento inicial (não superior a três meses); 2) trabalho coletivo com isolamento celular noturno; 3) transferência para colônia penal ou estabelecimento assemelhado; 4) O livramento condicional. Os crimes de menor gravidade eram punidos com a pena de detenção onde o condenado não se submetia ao período inicial de isolamento e podia trabalhar em serviços adequados a suas aptidões ou compatíveis com suas ocupações anteriores. (GOULART, 1994, p. 43)

Observamos que a regra do $\$ 2^{\circ}$ do artigo 30 que previa a transferência do interno de "bom procedimento" para colônia penal ou estabelecimento similar após cumprimento de um lapso temporal (metade da pena inferior a três anos ou um terço da pena superior a três anos) indica e adoção do sistema progressivo baseado na aferição de requisitos subjetivos e objetivos.

No entanto, o respeito às garantias individuais e coletivas somente se efetivou com promulgação da Constituição democrática em 18/09/1946 (DOTTI, 1998, p. 7071). A referida carta magna estabelecia expressamente no artigo 141 as garantias da irretroatividade in pejus da lei penal, e da individualização (\$29) e da personalização da pena $(\S 30)$.

Com a edição das "Normas Gerais do Regime Penitenciário" (Lei 3.247 de 02/10/1957) tivemos o primeiro diploma legal nacional a indicar parâmetros básicos a serem seguidos na execução penal (In: ROIG, 2005, p. 354-360). Apesar de Rodrigo Roig (2005, p. 125) bem observar que a Lei 3.247/1957 "compilava normas gerais acerca do regime penitenciário, normas estas de caráter eminentemente programático e organizacional, sem significativos reflexos na realidade carcerária".

No entanto, não podemos deixar de destacar o pioneirismo da referida norma no ordenamento jurídico brasileiro em estabelecer alguns aspectos programáticos referentes à execução penal a serem respeitados em todo território nacional. Esse diploma legal fazia referência expressa à individualização da pena de acordo com a personalidade do sentenciado e sua classificação "com o objetivo de estudar-lhes a personalidade, 
individualizar-lhes o tratamento corretivo e educacional [...] e distribuí-los pelos estabelecimentos adequados" (art. $3^{\circ}$ ). Também previa que a educação dos sentenciados observaria "índices psico-pedagógicos" (art. 9) e deveria ser orientada a escolha de uma profissão com o objetivo de readaptá-los ao meio social (art. 22). Todavia, destacamos que a referida lei não fazia referência expressa a regimes prisionais diferenciados (como fechado ou outro) para a execução das penas, não indicava espécies de penas (como reclusão ou detenção) e não indica critérios para progressão de regime, tão somente previa a existência de "Institutos" ou "Gabinetes de Biotipologia Criminal" (artigo 35, alínea i) destinados a classificação dos sentenciados e realização de exames de psicológicos ${ }^{7}$.

No ano de 1969, o Regime Militar pretendeu que se editasse às pressas um novo Código Penal baseado no anteprojeto de Nelson Hungria, cujos trabalhos foram iniciados em 1961 e interrompidos em 1965. Pelo anteprojeto, o caráter reeducativo da pena privativa de liberdade deveria predominar frente à primitiva feição punitiva da privação de liberdade. Assim, observa Alípio Silveira (1965, p. 62) que “o anteprojeto do Ministro Nelson Hungria, acentua clara e expressamente essa função, dominante se não praticamente única da pena, no direito penal contemporâneo". René Ariel Dotti (1998, p. 72-73) ressalta o objetivo "finalístico" do anteprojeto ao prescrever "a execução programada para se obter uma individualizada ação educacional buscando a gradativa recuperação social do Condenado.” O Código Penal (Decreto Lei 1.004 de 21/10/1969) manteve como modalidades de penas privativas de liberdade a reclusão e detenção (arts. 36 e 37), classificou os estabelecimentos prisionais em industriais, agrícolas, mistos (art.39) ou estabelecimento penal aberto (art. 40). Neste último também cumpriria pena o "condenado de bom comportamento que demonstre readaptabilidade social", em uma fase da execução progressiva que antecederia ao livramento condicional (art. $40, \S 1^{\circ}$ ).

No entanto, diversos diplomas legais foram editados para modificar o Código Penal de 1969, que teve sua efetiva vigência sucessivamente adiada até ser expressamente revogado pela Lei $\mathrm{N}^{\circ} 6578$ em 11 de outubro de 1978. No escopo do trabalho em tela, destacamos a importância da Lei 6.016, de 31 de dezembro de 1973, que alterava diversos dispositivos relacionados à execução penal. A lei manteve a classificação dos

\footnotetext{
${ }^{7}$ Temos aqui a previsão de estabelecimento penitenciário que desempenharia algumas das funções do Centro de Observação Criminológica, atualmente previsto pela Lei de Execução Penal.
} 
estabelecimentos prisionais (industrial, agrícola ou misto), mas alterou o art. 38 que passava então a indicar as regras para o cumprimento da pena no estabelecimento penal fechado (de segurança máxima) e no estabelecimento penal aberto. No primeiro seriam recolhidos "os condenados por tempo igual ou superior a seis anos de reclusão ou oito anos de detenção" e "os condenados por tempo inferior a esses limites, que sejam de acentuada periculosidade" (art. 38, $\S 1^{\circ}$ ). Já no estabelecimento penal aberto, cumpririam pena "em regime de semiliberdade os condenados por tempo inferior a seis anos de reclusão ou oito anos de detenção, que sejam de escassa ou nenhuma periculosidade" (art. 38, $\S 3^{\circ}$ ). Também seria instituída, via de regra, a proibição do isolamento celular diurno (art. $38, \S 2^{\circ}$ ). Ainda passava a prever a "prisão-albergue" para o condenado "primário e de nenhuma ou escassa periculosidade" (art. 40). De acordo as regras da Lei 6.016/1973, admitir-se-ia a progressão do estabelecimento prisional fechado para aberto, comprovada a redução da periculosidade do condenado (art. 38, $\S 4^{\circ}$ ), mas se puniria a fuga do estabelecimento aberto ou da prisão albergue com a regressão ao estabelecimento fechado (art. 38, $\S 5^{\circ}$ e art. 40, $\S 2^{\circ}$ ). Mesmo com estas alterações, a sistemática instituída no Código de 1969 ainda seria falha, pois não indicava os critério de classificação da periculosidade do condenado, nem como seria mensurada a sua evolução durante a execução da pena e ainda não obrigava a instituição dos Centros de Observação Criminológicos.

Note-se então que, desde edição do Código Penal em 1940 até aquele momento histórico, não houve mudanças significativas nas normas que regulamentavam as regras para progressão do regime de execução penal. A única legislação extravagante vigente no direito nacional eram as "Normas Gerais do Regime Penitenciário", datadas de 1957 e que possuíam apenas "caráter programático" e não tinham "efetividade concreta" (ROIG, 2005, p. 125).

Nos anos de 1975 e 1976, foi instaurada na Câmara dos Deputados uma Comissão Parlamentar de Inquérito com objetivo de levantar dados a respeito da situação penitenciária nacional à época. René Ariel Dotti (1998, p. 87) observa que: “As conclusões do relatório foram as mais pessimistas face às graves e elementares violações de direitos humanos dos prisioneiros, em desobediência às exigências da Lei 3.274/1957 e da regra estabelecida na constituição de 1967: "Impõe-se a todas as autoridades o respeito à integridade física e moral do detento e do presidiário" (art. 150, §14).” Sob este quadro foi então editada, em 24 de maio de 1977, a Lei 6.416 que, apesar de não criar uma 
regulamentação autônoma para a execução penal, mostrava clara tendência de se evoluir nesse sentido ao promover alterações importantes na redação original do Código Penal de 1940, no Código de Processo Penal e na Lei das Contravenções Penais, estes de 1941. José Eduardo Goulart (1994, p. 43) afirma que "operou-se em 1977, por via da Lei 6.416, substanciais alterações no sistema referido, em especial, quanto aos regimes de cumprimento da pena"

Dentro da temática de nosso trabalho, passamos a analisar as alterações legislativas operadas nos artigos 30 e 31 do Código de 1940, pois trouxeram importantes inovações em alguns aspectos relativos à execução progressiva da pena privativa de liberdade. Destacamos a exigência de procedimento de observação e classificação do condenado durante o período de observação inicial (que não podia ser superior a três meses) para o conhecimento da personalidade do condenado (art. 30, caput). Tal diploma legal também instituiu os regimes de cumprimento da pena fechado, semiaberto e aberto (art. $30, \S 5^{\circ}$ ), de modo a individualizar a execução de acordo com a culpa e a periculosidade do condenado. O regime fechado era previsto para a pena superior a oito anos, o regime semiaberto destinava-se às penas entre quatro e oito anos e o regime aberto para "condenados não perigosos" com pena de até quatro anos. A progressão do regime fechado para o semiaberto se daria após o cumprimento de um terço da pena superior a oito anos. A passagem do regime semiaberto para o aberto também poderia ocorrer após o cumprimento de um terço da pena inferior a oito anos e dois quintos da pena superior a oito anos.

René Ariel Dotti (1998, p. 87-88) salienta a importância da Lei 6.416/1977 na "instituição dos regimes (fechado, semiaberto e aberto) para individualizar a execução de acordo com a culpa e a periculosidade do condenado; a indicação concreta dos requisitos para o ingresso, a transferência ou o retorno nos regimes; [...] a exigência do procedimento de observação e classificação do condenado." Nota-se nesse momento uma preocupação em instituir um sistema para a execução da pena de modo a adaptar e preparar o apenado para o gradual e progressivo retorno à liberdade plena. Porém, em nosso entendimento, a redação dada por essa lei aos $\S \S 6^{\circ}$ e $7^{\circ}$ do art. 30 do Código Penal de 1940 apresenta uma falha ao deixar de instituir critérios nacionais unos para os requisitos subjetivos a serem aferidos nos pedidos de progressão de regime prisional e deixar esta importante tarefa a cargo da legislação estadual local ou a cargo de provimento do Conselho Superior da Magistratura ou órgão equivalente. 
A mini reforma de 1977 não conseguiu modificar substancialmente a situação em que se encontrava o sistema penitenciário brasileiro no final dos anos 70. A doutrina especializada continuava defendendo a instituição imediata de uma codificação nacional autônoma para o direito das execuções penais. Nesse contexto, Claudio Heleno Fragoso (1980, p. 44) ao discorrer sobre os "Direitos dos Presos" observa que:

"Quanto aos direitos dos presos, temos outras conclusões. A mais importante é a da urgente necessidade de um Código das Execuções Criminais, através do qual se introduza a lei no mundo da prisão, definindo a condição jurídica do preso e disciplinando os seus direitos. Convém provocar os tribunais, confiando na imaginação criadora e na vocação democrática dos juízes, pondo em causa princípios constitucionais do ordenamento e as leis em vigor. Os tribunais têm que penetrar nas prisões"

Seguindo essa orientação, foi empreendido em 1981 um novo movimento para a reforma dos Códigos em vigor. O Ministro da Justiça Ibraim Abi-Ackel, designou a tarefa de redigir anteprojeto para a Lei de Execução Penal a uma comissão de juristas integrada pelo Professores Francisco de Assis Toledo (coordenador dos trabalhos), Benjamin Moraes Filho, Miguel Reale Júnior, Negi Calixto, Renê Ariel Dotti, Ricardo Antunes Andreucci, Rogério Lauria Tucci e Sérgio Marcos de Moraes Pitombo (GOULART, 1994, p. 70). O trabalho da comissão resultou na edição da Lei 7.210, de 11 de julho de 1984, que instituiu a Lei de Execução Penal no ordenamento brasileiro, conferindo enfim a autonomia tão ensejada. A Reforma Penal de 1984 também trouxe uma nova regulamentação para parte geral do Código Penal de 1940 com a edição da Lei 7.209/1984.

No próximo capitulo passamos a tratar da regulamentação introduzida por estes diplomas legais no ordenamento brasileiro, destacando os pontos principais dentro da delimitação temática adotada no presente trabalho. 


\section{A REFORMA PENAL DE 1984 E A LEI DE EXECUÇÃO PENAL}

\subsection{Generalidades}

A edição da Lei de Execução Penal "constitui-se, sem dúvida, em importante avanço, retirando do limbo jurídico em que sempre esteve a matéria da execução da pena" (GOULART, 1994, p. 75). Naquele momento histórico de nosso país, o direito das execuções penais era reduzido a princípios gerais e regras de proteção aos condenados positivados de maneira esparsa no ordenamento e a único diploma legal que tratava especificamente do assunto era a Lei 3.274/1957 ("Normas gerais do regime penitenciário"). No entanto, de acordo com o item 184 da exposição de motivos da Lei de Execução Penal (In: RANGEL, 1983, p. 79), os comando previstos nesta lei não são verdadeiras normas jurídicas tanto no aspecto material ("porque ineficazes nos casos concretos e, assim, inaplicáveis") como no aspecto formal ("porque não contém o elemento de coercibilidade, consistente na sanção para o descumprimento do comando emergente da norma"). Essas normas gerais foram sistematicamente desprezadas pelo judiciário e pela administração pública ao longo dos mais de vinte anos de sua vigência.

Com a Reforma Penal de 1984 temos claramente a superação do antigo posicionamento que entendia que a União não deveria (ou não poderia) legislar sobre as regras jurídicas fundamentais para regulamentação do regime penitenciário em plano nacional. O item 7 da exposição de motivos da Lei de Execução Penal (In: RANGEL, 1983, p. 67) advoga a necessidade de adoção de uma codificação nacional para o direito das execuções penais, uma vez que "a etapa de cumprimento das penas ou medidas de segurança não se dissocia do Direito Penal, sendo, ao contrário, o esteio central de seu sistema, não há como sustentar a ideia de um Código Penal unitário e leis de regulamentos regionais de execução penal". Somente com a adoção de uma lei específica e abrangente poderíamos equacionar no plano nacional as questões referentes à intervenção jurisdicional, à atuação dos organismos administrativos, e ao tratamento penal em suas diversas fases e estágios da execução. 
Assim posto, havia um paradoxo ao editar-se um único Código Penal brasileiro para indicar os crimes e as penas aplicáveis em razão de seu descumprimento e diversos diplomas regionais para regulamentar os parâmetros de execução da pena privativa de liberdade imposta. Assim, para um mesmo fato típico praticado, poderíamos ter a adoção de diferentes tratamentos penais em razão do local de cumprimento da pena. Há nesse modelo um desrespeito total ao principio constitucional da isonomia que também é informador do Direito da Execução Penal.

A reforma de 1984 procurou solucionar esse problema e também buscou dar autonomia científica ao Direito da Execução Penal no Brasil por meio da instituição de uma codificação executiva nacional em sintonia com os dogmas do Direito Penal moderno, compatibilizando o Direito Penal da culpa com a execução humanitária das penas (DOTTI, 1982, p. 602). O perfil ideológico que orientou os trabalhos de elaboração da nova legislação penal e penitenciária brasileira, conforme observado por Miguel Reale Júnior (1985, p. 48), procurou seguir:

"uma postura realista, sem ortodoxia e comprometimentos teóricos,
instaurando-se um realismo humanista, que vê a pena como reprimenda; que
busca harmonizar o Direito Penal recorrendo a novas medidas que não o
encarceramento; que pretende fazer da execução da pena a oportunidade
para sugerir a suscitar valores, facilitando a resolução de conflitos pessoais
do condenado, mas sem a presunção de transformar cientificamente sua
personalidade"

Nesse panorama, René Ariel Dotti (2009) observa que "a culpabilidade é o primeiro indicador para a pena-base" e que, pelo principio da proporcionalidade, a pena aplicável deve partir do binômio necessidade/suficiência para a reprovação e prevenção do crime. Sergio Pitombo (1984), por sua vez salienta que "o ponto sancionatório há de encontrar-se, pois, na justa intersecção de duas linhas: a do punir e a do humanizar." Este autor observa que o juiz, no momento de fixação da pena, em respeito ao princípio da individualização, deverá avaliar os aspectos referentes à culpabilidade, antecedentes, conduta social e personalidade do condenado, além de analisar os motivos, as circunstâncias e as consequências do crime, bem como o comportamento da vítima.

Além disso, temos que o legislador de 1984 orientou-se no sentido de também ampliar a garantia da individualização penal para a para a fase de execução da pena, 
que também passa a se realizar sob orientação cientifica a partir de então. Por fim, o principio da individualização da pena ainda foi positivado no Art. $5^{\circ}$, XLVI, da Constituição Federal promulgada em 1988.

No entanto, para que haja uma efetiva execução científica da pena é necessário que o cumprimento dela se faça em o regime compatível e adequado às características pessoais do condenado (Art. $5^{\circ}$, XLVIII da CFB 1988). Na prática, o respeito à individualização da pena exige a observação da culpabilidade e do binômio necessidade/suficiência para a definição do regime de cumprimento adequado naquele momento da execução. Para atender essa necessidade, a Lei de Execução Penal prescreve então que os condenados à pena privativa de liberdade sejam submetidos a procedimento de classificação com vistas à individualização. Sobre este procedimento, Cesar Roberto Bitencourt (1998, p. 266) observa que "a classificação dos condenados torna-se requisito fundamental na nova concepção penitenciária e é o desdobramento natural do princípio constitucional da personalidade da pena (que nunca deverá passar da pessoa do criminoso)". Nesse ponto, observamos que a reforma de penal de 1984 pretendeu dar efetividade ao principio constitucional da personalidade da pena por meio do procedimento de classificação do condenado.

A classificação se dará no início do cumprimento da pena e será feita de modo a possibilitar o tratamento penitenciário indicado a cada condenado, em função de sua personalidade e considerando-se as particularidades do crime praticado. O item 26 da exposição de motivos da LEP (In: RANGEL, 1983, p. 68) ainda observa que "a classificação dos condenados é requisito fundamental para demarcar o início da execução científica das penas privativas da liberdade e da medida de segurança detentiva”.

Para compatibilizar o caráter retributivo, que o próprio cumprimento da pena privativa de liberdade enseja, com respeito a esses preceitos, a reforma de ampliou o sistema progressivo de execução já vigente. Pelas novas regras, as penas privativas de liberdade podem ser de "reclusão" ou de "detenção" e seu cumprimento poderá ser realizado sob um dos três tipos de regime: fechado, semiaberto ou aberto.

Podemos resumir a sistemática adotada pelo Código Penal e pela Lei de Execução Penal da seguinte forma: a sentença condenatória deve compatibilizar a reprimenda a ser 
imposta com o binômio "necessidade/suficiência" para a reprovação e prevenção do crime. Deve-se também observar os princípios da personalidade e da individualização da pena, tanto na fase de conhecimento como na execução. Assim, a execução da pena ocorrerá de forma progressiva, iniciando o cumprimento em um regime mais rigoroso, com a diminuição gradativa das restrições impostas até que apenado possa retornar ao convívio social em liberdade através do Livramento Condicional.

Prosseguirmos então o presente capítulo indicando os dispositivos legais que regulam cada um desses institutos na legislação introduzida pela Reforma Penal de 1984.

\subsection{As modalidades da pena, os estabelecimentos penitenciários e os regimes de execução penal}

$\mathrm{O}$ art. 32 do Código Penal prevê, entre as categorias de penas, a pena privativa de liberdade. Já o seu art. 33 indica que a "reclusão" e a "detenção" são as modalidades da pena privativa de liberdade. Este mesmo artigo também define os três regimes possíveis para a execução da penas: "fechado"; "semiaberto"; e "aberto", e os artigos seguintes $(34,35$ e 36 , respectivamente) prescrevem as regras para execução da pena em cada um dos três regimes, sem impor diferenças para a pena de reclusão ou de detenção.

A pena de reclusão é aquela que se executa em regime fechado, semiaberto ou aberto, ao passo que a detenção será cumprida em regime semiaberto ou em regime aberto. No entanto, o condenado à pena de detenção também poderá cumpri-la em regime fechado por necessidade de regressão de regime de acordo como art. 118 da LEP.

A Lei de Execução Penal também definiu os estabelecimentos penais adequados ao cumprimento de determinado regime prisional. A penitenciária destina-se ao cumprimento da pena em regime fechado (arts. 87 a 90), sendo um estabelecimento de segurança máxima ou média (art. $33, \S 1^{\circ}$, a, do CPB). Já a pena em regime semiaberto será cumprida em Colônia Agrícola, Industrial ou Similar (arts. 91 e 92 da LEP e art. 33, § $1^{\circ}$, b, do CPB). Por seu turno, a Casa do Albergado (arts. 93 a 95 da LEP e art. 33, §1º, c, do CPB) é o estabelecimento indicado para a execução da pena privativa de liberdade em regime aberto. 
Notamos que a Reforma Penal de 1984 manteve a diferenciação tradicional das penas privativas de liberdade entre reclusão e detenção, no entanto não há mais previsão legal para o tratamento diferenciado dentro do mesmo regime (fechado, semiaberto ou aberto) para um condenado com reclusão e outro com detenção. Álvaro Mayrink da Costa (1994, p. 253) salienta que a sistemática antiga do código de 1940, que previa a diferenças na execução da reclusão e da detenção dentro de um mesmo regime (v.g. separação, período de isolamento, escolha de trabalho etc.) foi abolida, bem como também não há mais previsão do isolamento celular e do período de silêncio como etapas do sistema progressivo.

Apesar novo sistema prever que a culpabilidade é a regra para a definição da pena e do regime de execução (conforme os critérios previstos no art. 59 do CPB), na prática, o que determina o regime inicial será a quantidade de pena e a reincidência (art. $33, \S 2^{\circ}$ do CPB). Assim, o condenado a uma pena superior a oito anos deverá começar a cumpri-la em regime fechado. Para o condenado não reincidente, a pena superior a quatro anos e inferior a oito anos poderá ser iniciada em regime semiaberto e a pena inferior a quatro anos já poderá começar a ser paga no regime aberto. O reincidente punido com nova pena de reclusão deverá iniciá-la obrigatoriamente em regime fechado, independente da sua duração, e o condenado reincidente punido com uma nova pena de detenção poderá cumpri-la em regime semiaberto.

Em suma, podemos diferenciar a reclusão da detenção pela diversidade dos regimes e pela natureza do estabelecimento penal adequado ao regime. $\mathrm{O}$ regime fechado, em regra, só se aplica aos apenados com reclusão e sua execução deverá ser realizada em uma penitenciária, de segurança máxima ou média. O regime semiaberto será cumprido em colônia penal agrícola ou estabelecimento similar, de segurança média ou mínima. O regime aberto será cumprido na casa do albergado, estabelecimento de segurança mínima. As regras destes dois últimos regimes são aplicáveis tanto para pena de detenção como para pena de reclusão.

José Eduardo Goulart (1994, p. 45) salienta que, “embora o período de duração de ambas as penas possa ser o mesmo, o sofrimento, não. E a pena como necessidade amarga que é, não se pode despir de sua natureza aflitiva, concebida como sofrimento e dor”. Como exemplo, podemos comparar as penas aplicáveis aos crimes de homicídio simples e Infanticídio (art. 121, caput e art. 123, caput, ambos do CPB) que embora possam ter a mesma duração, mas serão executadas de forma diversa, sendo que a reclusão aplicada ao homicida o poderá ser iniciada em regime fechado e mais rigoroso do que o regime 
semiaberto indicado á pena de detenção aplicada ao infanticida. Neste exemplo também podemos identificar que o Código atribui uma menor reprovabilidade à conduta de quem age sob influência do estado puerperal. Desse modo, podemos considerar que:

"Assentada a diferenciação entre reclusão e detenção na natureza das coisas, em razão do juízo de distinção interior que se faz ao aplicá-las, não apenas a diferença dos elementos típicos determina punição diversa, mas também a reprovabilidade da conduta, numa concepção normativa que se coloca em linha de consideração" (GOULART, 1994, p. 44 e 45)

Feitas essas considerações a respeito das penas dos regimes e dos estabelecimentos prisionais, passamos a tratar da individualização prevista no art. $5^{\circ}$, XLVIII da CFB 1988.

\subsection{A individualização penal nas fases de conhecimento e de execução e a progressão de regime prisional}

No tocante a fixação da pena, observamos que o sistema do Direito Penal brasileiro busca aplicar uma pena justa, adequada e suficiente para a reprovação e prevenção do crime de acordo com a personalidade do agente e das circunstancias do fato. $\mathrm{Na}$ aplicação da pena, o juiz irá realizar a primeira etapa da individualização judicial. Desse modo, ele deve observar a culpabilidade, os antecedentes, a conduta social e a personalidade do agente; os motivos, às circunstâncias e consequências do crime; e também o comportamento da vítima; assim ele deve fixar uma pena "conforme seja necessário e suficiente para reprovação e prevenção do crime", definindo sua modalidade, sua duração e o regime inicial de execução. (art. 59 do CPB).

De acordo com essa regra, Sergio Pitombo (1999) observa então que "a pena, hoje, guarda os três aludidos parâmetros: qualidade, quantidade e intensidade de sofrimento." Tal disposição legal reflete os preceitos do direito penal da culpabilidade, sendo que a qualidade refere-se ao tipo de pena aplicável dentre as possíveis, a quantidade refere-se á duração da pena imposta e a intensidade de sofrimento implica ao regime determinado para sua execução. Os dois primeiros parâmetros, modalidade de pena aplicável (reclusão ou detenção) e o tempo de sua duração, necessariamente devem ser fixados pelo Juiz ao proferir a sentença condenatória, ao passo que o terceiro deve ser imposto por este Juiz, mas em caso 
de sua omissão deve ser determinado pelo Juiz responsável pela Execução Penal. Sobre este ponto, Sergio Pitombo (1984) ressalta que "a fixação do regime inicial de execução das penas privativas de liberdade integra, por necessário, o ato decisório penal definitivo", assim, "ao juiz da ação, na sentença condenatória, cabe determinar o regime inicial de cumprimento de pena." O autor Cézar Roberto Bitencourt (1998, p. 260) observa, contudo, que a Lei 7209/1984 abandonou, na determinação do regime inicial de cumprimento da pena, a "periculosidade" do agente como fator determinante para adoção deste ou daquele regime, como fazia a Lei 6416/1977.

A individualização da pena na fase de execução é iniciada com a "Classificação" dos condenados. O procedimento de classificação está regulamentado nos $\operatorname{artigos} 5^{\circ}$ a $9^{\circ}$ da Lei de Execução Penal e tem como objetivo a adoção de medidas para o atendimento do principio constitucional da personalidade da pena (art. $5^{\circ}$, XLVIII, da CFB), pelo qual "a lei regulará a individualização da pena". Conforme observa José Eduardo Goulart (1994, p. 76-77), a individualização da pena na fase executória busca "particularizar a execução da pena à pessoa do condenado" e "especializar a execução tendo em vista a personalidade do sentenciado". Tudo isso, norteado pelo art. $1^{\circ}$ da Lei de Execução Penal, que coloca como objetivos da execução penal "a efetivação das disposições de sentença" e a garantia de "condições para a harmônica integração social do condenado".

A classificação será feita "segundo os seus antecedentes e personalidade, para orientar a individualização da execução penal" (art. $5^{\circ}$ da LEP). A “classificação será feita por Comissão Técnica de Classificação que elaborará o programa individualizador e acompanhará a execução das penas privativas de liberdade [...], devendo propor, à autoridade competente, as progressões e regressões dos regimes" (art. $6^{\circ}$ da LEP, redação original). Desse modo, a classificação do condenado, será realizada pela CTC logo no início da internação, segundo critérios científicos e terá fundamental importância para o planejamento da execução, pois objetiva inserir o condenado em um regime adequado a sua personalidade.

Em sequência, passamos a destacar o sistema progressivo dos regimes de cumprimento da pena privativa de liberdade na sistemática da Lei de Execução Penal e do Código Penal. 
Retomamos então a definição de regime penitenciário de Sérgio Pitombo (1984), pela qual o regime diz respeito à "intensidade da restrição à liberdade" que se impõe ao condenado durante a fase de execução. A reforma de 1984 determinou que a execução das penas privativas de liberdade continuasse a ser feita de maneira progressiva. Tal dispositivo encontra-se positivado no Código Penal (art. 33, § $2^{\circ}$ ) e na Lei de Execução Penal (art. 112)

Nessa sistemática, temos que a sentença condenatória determinará apenas o regime inicial de cumprimento da pena imposta ao condenado. Assim, ela será uma decisão provisória e passível de modificação durante a fase de execução. Nesse sentido, Sérgio Pitombo (1984) atenta para a possibilidade de "mudanças de regime que se concretizam na decisão fundamentada do juiz a quem competir a execução penal". Podemos observar então que a decisão condenatória cujo dispositivo determina o cumprimento de pena privativa de liberdade em regime inicialmente fechado ou semiaberto (art. 110 da LEP) possibilita ao condenado que se beneficie da progressão (art. 112 da LEP), ou que seja punido com posterior e eventual regressão (art. 118 da LEP).

A possibilidade de regressão para um regime mais rigoroso do condenado que vier frustrar os objetivos do novo regime, com graves prejuízos á defesa social e aos fins da pena reflete a preocupação da Reforma Penal em compatibilizar o respeito aos direitos individuais com a garantia da defesa social. Cézar Roberto Bitencourt (1998, p. 265) observa que a LEP, “ao adotar a progressão como instituto democrático e recomendável na recuperação do condenado, não podia deixar sem remédio a hipótese de o condenado beneficiado pela progressão vir, posteriormente, a demonstrar sua incompatibilidade com o novo regime".

O professor Sergio Pitombo (1984) observa que “A mudança progressiva [...] vem ao empuxo do merecimento demonstrado, vedando-se a execução por saltos. Já se percebe a impossibilidade de transferência direta do regime fechado para o aberto." Assim, temos com a reforma de 1984 a instituição da progressão no regime de execução como uma conquista do condenado que se condiciona ao seu merecimento.

Para que o condenado possa pleitear a progressão em seu regime prisional, o mesmo deve atender aos requisitos subjetivos e objetivos previstos no art. 112 da LEP. Desse modo 
ele deverá necessariamente cumprir um lapso temporal mínimo ${ }^{8}$ de 1/6 (um sexto) da pena no regime inicial ou no regime anterior e ainda deve "seu mérito indicar a progressão" (art. 112 da LEP, redação original). O Sistema instituído não prevê nem admite a passagem direta do regime fechado para o aberto, a denominada progressão per saltum (item 120 da exposição de motivos da LEP, IN: RANGEL, 1983, p. 75), pois é indispensável que o apenado demonstre gradativamente sua recuperação, adaptabilidade e que está realmente preparado para cumprir o restante da sanção imposta em um regime menos rigoroso sem prejudicar os fins da pena.

Mas então o que vem a ser o "mérito" do condenado? Como ele será aferido? Embora a lei não seja objetiva a esse respeito, a resposta deverá ser extraída do sistema que a informa. Passamos então a tratar dos elementos considerados na aferição desse mérito.

\subsection{Critério subjetivo para a progressão: a questão do mérito}

Acabamos de observar, que a análise do "mérito" é o principal critério subjetivo avaliado para a progressão dos regimes prisionais, ou seja, "o mérito do sentenciado é o critério que comanda a execução progressiva" (item 29, da exposição de motivos da LEP, In: RANGEL, 1983, p. 68). Sabemos também que a progressão “deve ser uma conquista do condenado pelo seu mérito e pressupõe o cumprimento mínimo de um sexto da pena no regime inicial ou anterior" (item 119 da exposição de motivos da LEP. In: RANGEL, 1983, p. 75). Ainda temos que o vocábulo "mérito", deve ser compreendido no contexto de "aptidão, capacidade e merecimento, demonstrados no curso da execução" (item 120 da exposição de motivos da LEP. In: RANGEL, 1983, p. 75).

Assim, a progressão ou regressão nos regimes prisionais deve ser realizada com base na aferição do merecimento do condenado durante a fase de execução da pena.

\footnotetext{
${ }^{8}$ Observamos, porém, que para os condenados por crimes hediondos e equiparados, o lapso temporal a ser observado será o previsto no Art. $2^{\circ}$, §2 da Lei 8072/1990 (com redação dada pela Lei 11.464/2007), sendo necessário o cumprimento de $2 / 5$ (dois quintos) da pena para a progressão de regime prisional quando o apenado for primário ou o cumprimento de $3 / 5$ (três quintos) dela quando ele for reincidente.
} 
Dessa forma, necessitamos identificar como esse merecimento é aferido para qualificar o apenando a cumprir o restante da pena em regime com restrições menos rigorosas.

Quanto ao conceito de "mérito" na execução penal, retomamos a definição apresentada pelo professor Sérgio Pitombo (1999), onde "mérito, no andamento dos regimes prisionais, consiste, no juízo objetivo, que se ultima no processo de execução, do proceder do condenado; assim, valorando-o, em base de vários elementos, postos em relacionalidade, e ostentando em ato decisório motivado".

Para Miguel Reale Júnior (1985, p. 97) “o mérito do condenado é oferecido pelos seus valores morais e intelectuais, tornando-o digno de elogio e recompensa". No entanto, José Eduardo Goulart (1994, p. 79) salienta que "tal concepção não pode ser aceita, por dar margem a interpretações de ordem subjetiva, incompatíveis com o princípio da legalidade informador da Lei de Execução Penal"; e advoga que o "mérito" deve ser aferido com base em "elementos objetivos e que decorrem do próprio sistema da lei que regula a execução penal".

Para J. B. Torres de Albuquerque (2004, p. 45 e 46), “dentro do aspecto subjetivo para obtenção de uma progressão no regime carcerário prisional, o mérito do condenado se concentrará no que diz respeito a seu bom comportamento carcerário e aptidão para retornar a convívio social”.

Com base na análise dos diversos comandos da Lei de Execução Penal (em sua redação original), o mérito durante a execução da pena deve ser apurado considerando-se o comportamento do condenado no andar da execução; a submissão às normas de execução da pena (art. 38, última parte), o cumprimento de seus deveres (art. 39), a avaliação de sua disciplina e de seu desempenho no trabalho (art. 44) e o resultado do exame criminológico (arts. $8^{\circ}$ e 112, $\S$ único). Tudo isso assentado no parecer da Comissão Técnica de Classificação (arts. $6^{\circ}, 9^{\circ}, 112, \S$ único), que fará a verificação das condições pessoais e indicará se são o não compatíveis ou não com o novo regime (semiaberto ou aberto). Para a progressão ao regime aberto é exigido que o condenado esteja trabalhando ou possa imediatamente exercer emprego e também o ajustamento com responsabilidade e autodisciplina ao novo regime (art. 114). Assim, com base nas informações do parecer da Comissão Técnica de Classificação, o Juiz da execução terá subsídios para decidir sobre a 
progressão. No entanto, conforme observa Cézar Roberto Bitencourt (1998, p. 266), “esse parecer, como toda perícia, não vincula o magistrado, mas não deixa de ser subsídio importantíssimo a ser analisado [...] em seu ato decisório".

Nesse processo de avaliação, de acordo com Sérgio Pitombo (1999), não devemos observar separadamente esses diversos elementos formais que compõem o mérito, mas sim analisá-los em conjunto de modo a atribuir um valor ao mérito: positivo, negativo, ou ausente. Para ele, "O andamento progressivo ou regressivo do estado de condenado constituise, pois, em algo nascente a ele, durante o processo de execução, do mérito ou demérito, repita-se, e emergentes do parecer da Comissão Técnica de Classificação; bem como, por igual, do exame criminológico" (PITOMBO, 1984).

O Exame criminológico, por seu turno, consiste na "pesquisa dos antecedentes pessoais, familiares, sociais, psíquicos, psicológicos do condenado, para obtenção de dados que possam revelar a personalidade do mesmo" (BITENCOURT, 1998, p. 266). Já à Comissão Técnica de Classificação compete “elaborar o programa individualizador, [...] acompanhar a execução das penas privativas de liberdade, [...] propor ao juízo das execuções penais as progressões e regressões dos regimes, [...] emitindo os respectivos pareceres" (BITENCOURT, 1998, p. 266)

No sistema proposto pela Reforma Penal de 1984, o Exame Criminológico passa a ser a peça fundamental para o levantamento de informações a respeito da personalidade e das características subjetivas do condenado. São estes dados que servirão de subsidio para a classificação com vistas à individualização a ser proposta pela Comissão Técnica de Classificação. Devemos ter em mente que o principio da individualização deve orientar toda a execução da pena. Desse modo, o condenado deve ser avaliado não somente no inicio desse processo, mas também durante a execução, principalmente nas ocasiões em que são a ele concedidos benefícios que implicam em uma menor restrição a sua liberdade, como no caso da progressão de regime e do livramento condicional.

Devido à importância do Exame Criminológico na sistemática da execução progressiva da pena imposta pela Reforma Penal de 1984, passaremos dedicar o próximo capítulo do presente trabalho a uma abordagem mais minuciosa a respeito deste assunto. 


\section{A AVALIAÇÃO DOS ASPECTOS SUBJETIVOS DO CONDENADO E O EXAME CRIMINOLÓGICO NA REFORMA DE 1984}

Conforme já observamos anteriormente, a Reforma Penal de 1984 comprometeu-se com a execução cientificamente orientada da pena privativa de liberdade. Nessa concepção, a classificação dos condenados tornou-se requisito fundamental e desdobramento natural dos princípios constitucionais da personalidade e da individualização da pena. No procedimento de classificação a lei passou a prever avaliações técnicas para o levantamento de informações acerca das características biológicas, psicológicas e sociais dos condenados. Com base nos subsídios fornecidos é que ira se realizar a execução da pena, assim essas avaliações são de fundamental importância para orientar todo processo de execução e também informar o magistrado nos momentos de concessão de benefícios como progressão de regime e livramento condicional.

A Reforma Penal de 1984 passou então a prescrever o exame de personalidade, o exame criminológico e o parecer da Comissão Técnica de Classificação como as modalidades de avaliações técnicas que podem ser aplicadas aos encarcerados durante a execução da pena privativa de liberdade. Passamos então a discorrer a respeito dessas avaliações.

\subsection{A diferenciação entre exame de personalidade e exame criminológico}

De acordo com o item 34 da exposição de motivos da LEP (In: RANGEL, 1983, p. 69), o exame criminológico é uma espécie do gênero exame da personalidade. O exame criminológico "parte do binômio delito-delinquente, numa interação de causa e efeito, tendo como objetivo a investigação médica, psicológica e social", enquanto que o exame de personalidade é mais abrangente, pois busca avaliar o condenado "para além do crime cometido". O método usado nesses dois tipos de análise também é diferente, sendo o 
condenado no exame de personalidade submetido "a esquemas técnicos de maior profundidade nos campos morfológico, funcional e psíquico".

Alvino de Sá (2010, p. 205) considera que a questão da maior ou menor abrangência é o principal critério de distinção entre o exame criminológico e o exame de personalidade, e isso decorre da natureza e finalidade dos exames. Ele afirma que o exame criminológico é uma perícia enquanto que o exame de personalidade consiste em um exame clinico interdisciplinar da pessoa do condenado.

Para o autor primeira diferenciação reside no objeto das duas avaliações. Enquanto que o exame criminológico "enfoca o binômio delito-delinquente, buscando avaliar a dinâmica do ato criminoso", o exame de personalidade é mais amplo e voltado para a pessoa do condenado. Neste exame o interesse se volta para a "sua realidade integral e individual, incluída aí toda sua história, história de uma pessoa, e não mais de um criminoso". Já a segunda diferenciação diz respeito ao escopo do da avaliação, uma vez que o exame de personalidade tem como objetivo o "conhecimento amplo e profundo [...] da personalidade do apenado enquanto pessoa" e o exame criminológico destina-se "ao deslinde de uma questão jurídica, na medida em que informa a autoridade competente sobre a dinâmica do ato criminoso, foco de atenção nas decisões tomadas no âmbito da execução" (SÁ, 2010, p. 205206)

A LEP indica que o exame criminológico será realizado, via de regra, no Centro de Observação (art. 96) enquanto que o exame de personalidade será realizado pela CTC (art. $9^{\circ}$ ). Na realização deste exame, a comissão poderá entrevistar pessoas, requisitar dados e informações de estabelecimentos privados e ainda realizar outras diligências e exames complementares que julgar necessário.

\subsection{Parecer da Comissão Técnica de Classificação}

A terceira espécie de avaliação técnica do condenado é o Parecer da Comissão Técnica de Classificação, a ser elaborado para instruir a análise dos pedidos de progressão de regime (art. 112, § único, redação original da LEP). De acordo com a Lei de Execução Penal, este parecer será elaborado por técnicos da Comissão Técnica de 
Classificação existente em cada estabelecimento prisional, que consiste em uma equipe interdisciplinar presidida pelo diretor do estabelecimento e composta, por dois chefes de serviço, um psiquiatra, um psicólogo e um assistente social (art. $7^{\circ}$ ).

A Comissão Técnica de Classificação (CTC) deverá realizar o procedimento de classificação do apenado, elaborar o programa individualizador e acompanhar a execução de sua pena e ainda irá propor as progressões e regressões dos regimes à autoridade competente. (art. $6^{\circ}$ da LEP, redação original). Alvino Augusto de Sá (2010, p. 208 e 209) salienta que é necessário que a CTC participe de maneira ativa das atividades do presídio e que acompanhe os programas individualizadores por ela propostos. Para ele, a Comissão deve ter um papel proativo na execução, porque é quem melhor pode conhecer a individualidade do preso, o seu dia-a-dia, devendo saber o que é melhor para ele e por isso mesmo é ela a mais indicada para propor as progressões, regressões ou conversões.

Sob essa ótica, os subsídios para a construção do Parecer seriam obtidos pela CTC ao longo do acompanhamento diário do apenado durante o processo de internação. Para Alvino de Sá (2010, p. 208), na elaboração do Parecer, a CTC não procura avaliar o ato criminoso nem fazer um prognóstico de reincidência do condenado, assim o Parecer "consiste na avaliação da resposta que o preso vem dando aos programas individualizadores, às oportunidades que lhe têm sido oferecidas durante a execução de sua pena". Por fim, ele também descarta qualquer ideia de perícia no parecer das CTC, pois seria tecnicamente inviável e eticamente inadmissível, uma vez que a CTC faz o acompanhamento diário do interno e propõe os programas individualizadores a ele aplicados (SÁ, 2010, p. 209).

Podemos notar que o Parecer da CTC e o exame criminológico possuem naturezas e objetivos distintos. O Parecer, não se constitui de pericia, é elaborado por meio de dados e informes obtidos durante o período de internamento e tem por objetivo a avaliação da resposta do preso à terapêutica penal. Já o exame criminológico é uma avaliação pericial, que parte do binômio delito/delinquente, busca avaliar a dinâmica do ato criminoso e destina-se a servir como objeto de convicção do juiz na decisão dos pedidos de progressão de regime. $\mathrm{O}$ exame criminológico, no inicio da execução, em conjunto o exame de personalidade, também se destina a fornecer subsídios pra o processo de classificação inicial do condenado a ser realizado pela CTC. 
Feita a diferenciação entre os diferentes tipos de avaliações técnicas, passamos a tratar especificamente do exame criminológico sob a ótica da Reforma Penal de 1984.

\subsection{O exame criminológico}

\subsubsection{Conceito e definição}

De acordo com Cézar Roberto Bitencourt (1998, p. 266-267), podemos conceituar o exame criminológico como sendo um exame pericial que tem por objetivo buscar informações sobre a capacidade de adaptação do condenado ao regime imposto, sobre a probabilidade dele voltar ou não a delinquir e sobre a sua possibilidade de reinserção social, através de avaliações de natureza genética, antropológica, social e psicológica.

O professor Sergio Pitombo (1994), por sua vez, define o exame criminológico como "perseguição dos precedentes pessoais e familiares do condenado, sob os aspectos físicos, psíquico, moral e ambiental, para obtenção de informações reveladoras de sua personalidade".

Álvaro Mayrink da Costa (1994, p. XVIII) qualifica o exame criminológico como sendo um "instrumento técnico-científico multidisciplinar de avaliação da periculosidade [...], se constituindo no meio judicial de se evitar a reincidência e as reinserções antecipadas dos condenados por fatos gravemente censurados com maior margem de risco social" Para ele, é através do exame criminológico que podemos conhecer o criminoso em sua integralidade, e desse modo, pode-se então "vislumbrar uma justiça eficaz e apropriada, uma vez que a aplicação fria da norma penal, tomando como ponto de partida um critério de valoração político-jurídica, inevitavelmente, conduziria a enormes injustiças e monstruosos equívocos" (COSTA, 1994, p. 214)

Iremos então conceituar o exame criminológico como sendo a avaliação cientifica multidisciplinar do condenado, sob os aspectos biológico, psicológico e social, com 
objetivo de melhor se conhecer sua personalidade e assim obter os subsídios necessários para se individualizar a execução da pena e que também se propõe a avaliar a resposta do condenado ao tratamento penal, indicando a probabilidade de reincidência e a possibilidade de reinserção social do mesmo antes do cumprimento integral da pena.

\subsubsection{Finalidade e objetivos}

Cézar Roberto Bitencourt (1998, p. 267) observa que o exame criminológico será realizado com a finalidade "de fornecer elementos, dados, condições, subsídios, sobre a personalidade do condenado, examinando-o sob os aspectos mental, biológico e social, para concretizar a individualização da pena através dessa classificação dos apenados."

Odon Ramos Maranhão (1981, p. 40) também salienta que o exame criminológico tem por objetivo determinar a capacidade provável do condenado "de adaptarse ao regime executório; de não delinquir; e de reinserir-se na sociedade, numa visão pluridimensional da personalidade do agente".

Alvino Augusto de Sá (2010, p. 209) atribui ao exame criminológico o objetivo de obter os "informes pertinentes à avaliação da conduta criminosa, em si, persistência ou não dos fatores associados à mesma". Para ele, a observação criminológica tem por objetivo indicar "medidas a serem tomadas em relação ao preso, com vistas á otimização da execução de sua pena, propondo, [...] se for caso, um regime mais brando" e também deve oferecer "subsídios valiosos à Comissão Técnica de Classificação do presídio que receberá o reeducando"(SÁ, 2010, p. 196)

Álvaro Mayrink da Costa (1994, p. 209) considera que o "exame médicopsicológico-social" tem por finalidade "reunir o maior número de dados possíveis sobre a pessoa estudada, sendo que tal invasão é ditada pelo interesse da sociedade", e destina-se "não somente ao tratamento, mas também à adaptação social dos delinquentes".

Alípio Silveira (1965, p. 84-85) afirma que o exame criminológico tem por objetivo explorar a personalidade do acusado para determinação de sua culpabilidade, de sua capacidade para o crime e do perigo que representa, e ainda indicar as probabilidades de melhoramento e de adaptação. 
Cláudio Leotta de Araújo e Marco Antônio de Menezes (2003) observam que o exame criminológico, também deve ser realizado por uma questão de justiça, de respeito à democracia e com objetivo da recuperação do sentenciado. Eles salientam que:

\begin{abstract}
"Para criminosos diferentes, execuções de penas também diferentes, e o elemento orientador dessa individualização é o exame criminológico, já que não se dispõe de outro meio. Além disso, [...], o exame é a forma pela qual o magistrado tem como fundamentar sua decisão acerca da antecipação da liberdade do sentenciado e progressão regimental, antes de cumprida a pena na íntegra."
\end{abstract}

Destacamos então como finalidades básicas do Exame Criminológico o levantamento de informações para subsidiar a individualização executiva da sanção penal, para auxiliar a CTC no procedimento de classificação e assim colaborar para que haja uma adequada terapêutica penal, com objetivos reeducacionais e de combate à reincidência criminal, e ainda fornecer ao juízo das execuções informes sobre a adaptabilidade e condições pessoais do apenado para que ele possa cumprir o restante da pena em um regime mais brando ou mesmo se beneficiar do livramento condicional sem frustrar os fins da execução.

\title{
4.3.3 A natureza jurídica
}

Alvino Augusto de Sá (2010, p. 205-206) afirma que o exame criminológico, particularmente o que é feito para fins de instrução de pedidos de benefícios, trata-se de um exame pericial. Ele salienta que o exame reúne as características de uma perícia: é realizada por técnicos especializados, é um meio de prova, porque através dele são colhidos elementos sobre a dinâmica do ato criminoso e sobre sua probabilidade de reincidência, e presta-se a informar à autoridade no deslinde de uma questão jurídica.

Sergio Pitombo (1984) também adverte para não se privilegiar em demasia o exame criminológico, uma vez que ele consiste em perícia, em meio de prova; cuja valoração será livremente apreciada pelo Juiz da execução. Ele ainda observa que "a perícia, arrimando-se no labor de equipe interdisciplinar, deve ostentar a síntese criminológica. Isso implica um enquadramento de cada caso em itens de uma classificação, na seleção do destino a ser dado ao examinado e em medidas a serem adotadas" 
Sérgio Pitombo (1984) e Cézar Bitencourt (1988, p. 267) observam que, por ser um exame de natureza pericial, o Juiz não fica vinculado à conclusão que chegarem os peritos na elaboração do exame criminológico. O Juiz da execução pode decidir contrariamente ao recomendado pelo exame, desde que o faça por meio de decisão devida e suficientemente fundamentada, nos termos do art. 157 do Código de Processo Penal brasileiro.

Em outras palavras, reafirmamos que o exame criminológico possui natureza jurídica pericial, uma vez que o mesmo é feito por um corpo técnico multidisciplinar, destina-se a levantar os dados a respeito da personalidade do criminoso e de sua real situação pessoal durante a execução da pena (elementos de prova). Por fim, temos que os resultados obtidos se destinam a subsidiar a CTC na classificação dos internos e/ou informar o juiz da execução para que ele possa adequar o tratamento dispensado ao apenado durante a execução.

\subsubsection{Conteúdo}

Para Odon Ramos Maranhão (1981, p. 48) o exame criminológico procura explicar a dinâmica criminal (“diagnóstico criminológico"), propor medidas recuperadoras (“assistência criminiátrica"), além de ainda avaliar a possibilidade de delinquir (prognóstico criminológico). Em sua visão, os antecedentes e principalmente os prognósticos serão fundamentais para subsidiar a individualização da execução da sentença, pois uma vez melhor conhecidas tais características do apenado é possível se ajustar melhor os estágios da execução da pena. Desse modo, ele observa que, na realização do exame, "os informes sobre a periculosidade (no sentido de provável reincidência) e adaptabilidade (em sentido reeducacional) são básicos” (MARANHÃO, 1981, p. 50).

$\mathrm{Na}$ realização do exame criminológico, poderemos então utilizar alguns “instrumentos de verificação” (MARANHÃO, 1965, p. 41-50), a saber: informações jurídicopenais (como agiu o condenado, reincidência etc.); exame clínico (saúde individual e eventuais causas mórbidas relacionadas ao comportamento delinquente); exame morfológico (constituição somatopsíquica); exame neurológico (manifestações mórbidas do sistema nervoso); exame eletroencefalográfico (busca de "lesões focais ou difusas" e sua "correlação entre alterações funcionais do encéfalo e o comportamento"); exame psicológico (nível mental, traços da personalidade e agressividade); exame psiquiátrico (determinar alguma 
“perturbação mental”); e exame social (informações familiares, "condições sociais em que o ato foi praticado", etc.)

Alvino Augusto de Sá (2010, p. 190-191) divide o exame criminológico, em duas partes: o diagnóstico criminológico e o prognóstico criminológico.

No diagnóstico criminológico procura-se avaliar todo o contexto complexo do preso, a saber: "suas condições pessoais, orgânicas, psicológicas, familiares, sociais e ambientais em geral, que estariam associadas à sua conduta criminosa e que revelariam elementos para compreender tal conduta" (SÁ, 2010, p. 191-192). Ele afirma que o diagnóstico criminológico constitui-se em "uma análise interdisciplinar complexa e contextualizada de determinada conduta de um indivíduo, que o Direito Penal define como crime, na busca de compreendê-la e de situá-la dentro de todo o complexo contexto desse indivíduo" (SÁ, 2010, p.193). O diagnostico criminológico poderá ser elaborado com base nos “instrumentos de verificação” observados por Odon Ramos Maranhão (1965, p. 41-50).

Já o prognóstico criminológico é a consequência lógica ao diagnóstico criminológico. É nele que os técnicos devem expressar os possíveis desdobramentos futuros da conduta do examinado. Alvino de Sá (2010, p.193-194) salienta que o grande problema do prognostico no exame criminológico (problema este muito levantado pela literatura especializada) reside no fato de não podermos garantir com absoluta certeza a probabilidade de ocorrência ou não de um comportamento especifico no futuro. Desse modo, salienta o autor que não podemos confundir o diagnóstico criminológico com um diagnóstico de periculosidade e também não se pode tomar o prognóstico criminológico como um parecer de cessação de periculosidade (SÁ, 2010, p. 195)

\subsubsection{Antecedentes históricos e momento de realização}

Álvaro Mayrink da Costa (1994, p. 208) observa que a investigação da personalidade do criminoso por meio do exame médico-psico-social foi proposta pela primeira vez por Lombroso, no Congresso Internacional Penitenciário de St. Petersburg, em 1889. Nesta mesma época, Garofalo, defendia na Itália, que deveria se realizar uma enquete social associada ao exame médico-psicológico, uma vez que são complementares. O autor também lista uma série de Congressos e encontros internacionais (COSTA, 1994, p. 208-210), realizados no século passado, onde o assunto foi posto em pauta, dentre os quais destacamos: 
- 1925 - Congresso de Londres - propõe-se que seja estudada a organização de observação dos delinquentes;

- 1938, Roma - I Congresso Internacional de Criminologia - recomendava o estudo da personalidade do delinquente nas três fases do ciclo judiciário: instrução, julgamento e execução;

- 1950, Paris - II Congresso de Criminologia - defendia a necessidade do exame biotipológico e também a introdução da Psiquiatria nos estabelecimentos penitenciários;

- 1950, Haia - XII Congresso da Comissão Internacional Penal e Penitenciária adotou-se a seguinte resolução:

"Na organização moderna da justiça penal, é altamente desejável, para servir de base à fixação da pena e aos processos de tratamento penitenciário e de liberação, dispor de um relatório, previamente à prolação da sentença, o qual se referira não somente à circunstância do crime, mas também aos fatores relativos à constituição, à personalidade, ao caráter e aos antecedentes sociais e culturais do delinquente";

- 1951, Bruxelas - Ciclo de estudos europeus organizado pela ONU - indica que o exame médico-psicológico e social dos delinquentes deve compreender: a) um exame biológico, das características físicas em geral; b) um exame psicológico, que permite medir as faculdades, as aptidões e as realizações mentais e descrever as características da personalidade; c) um exame psiquiátrico; d) um exame social, com objetivo de conhecer a vida social do delinquente, participar em sua integração e contribuir para o tratamento;

- 1952 a 1955 - Cursos Internacionais de Criminologia organizados pela Sociedade Internacional de Criminologia - se dedicaram ao exame médico-psicológico e social dos delinquentes (1952), ao estudo do estado perigoso (1953), e à infração e à personalidade dos delinquentes (1953).

No Direito brasileiro, o anteprojeto de Código de Processo Penal de 1970 de autoria do Professor Frederico Marques indicava a realização do exame criminológico durante a instrução criminal (COSTA, 1994, p. 188-191). Por este projeto, o exame criminológico 
poderia ser realizado durante a fase de instrução criminal para o réu denunciado como: criminoso habitual ou como "criminoso por tendência"; para verificação da condição de inimputável (doente mental ou pessoa com desenvolvimento mental incompleto ou retardado) e substituição da pena pela internação; ébrio habitual ou toxicômano; e para o autor de crime cometido no exercício abusivo da profissão ou com grave transgressão de deveres profissionais.

A Reforma Penal de 1984, no entanto, não admitiu a realização do exame criminológico durante a fase de conhecimento. O legislador pátrio tomou a opção de direcioná-lo apenas para o condenado, excluindo a realização do mesmo enquanto ele estiver sendo processado. Em respeito ao princípio da prevenção de inocência e devido às peculiaridades da investigação realizada através do exame criminológico, este só deverá se realizar depois de declarada a culpa ou a periculosidade do sujeito (item 30 da exposição de motivos da LEP, In: RANGEL, 1983, p. 69)

Álvaro Mayrink da Costa (1994, p. 227) salienta que a questão relativa à legitimidade jurídica do exame criminológico realizado durante a fase de instrução criminal suscita graves controvérsias no direito comparado", uma vez que "tal tipo de investigação criminológica pode invadir a intimidade do ser humano, podendo trazer grandes abalos à estrutura psíquica”. Sérgio Pitombo (1984) observa que o exame só deve ser realizado depois da "sentença condenatória restar fixada e declarada a culpa penal de forma definitiva. A presunção de inocência o arreda do processo de conhecimento, com vistas à peculiar investigação do delito e do delinquente, que lhe é própria".

Observamos ainda que, pela sistemática da Constituição Federal de 1988, somente após o transito em julgado da sentença condenatória é que haverá a quebra da presunção de inocência (art. $5^{\circ}$, LVII). Assim, seria questionável a legitimidade do estado em determinar a realização do exame criminológico pessoa que se presume inocente, invadindo a sua privacidade e intimidade $\left(\operatorname{art} .5^{\circ}, \mathrm{X}\right)$.

\footnotetext{
${ }^{9}$ Não nos ateremos a tecer maiores comentários sobre a realização do exame criminológico durante a fase de instrução criminal e julgamento uma vez que a Reforma Penal de 1984 não admitiu tal procedimento em razão do princípio da presunção de inocência. Para maiores detalhes sobre esse ponto recomendamos leitura dos autores Álvaro Mayrink da Costa (1994, p. 101-108 e 217-226) e Alípio Silveira (1965, p. 61-65)
} 
A Reforma Penal de 1984 previu então a realização do exame criminológico no início da execução da pena e no momento de concessão de benefícios como a progressão de regime e livramento condicional que diminuem as restrições impostas ao condenado.

\subsubsection{O exame criminológico de entrada.}

Já vimos que o exame criminológico busca melhor conhecer a personalidade do condenado e os fatores que provavelmente o levaram à delinquir e pode fornecer subsídios para que ele seja submetido a um tratamento adequado com objetivo de prevenção criminal. Por esse motivo, a Lei de Execução Penal prevê a realização desse exame no início do cumprimento da pena, "para a obtenção dos elementos necessários a uma adequada classificação e com vistas à individualização da execução" (art. $8^{\circ}$, caput, da LEP). O caput do art. 34 do CPB também indica que o condenado em regime inicialmente fechado "será submetido, no início do cumprimento da pena, a exame criminológico de classificação para individualização da execução". Já o art. 35 do CPB prevê a aplicação do comando do art. 34 [...] ao condenado que iniciar o cumprimento em regime semiaberto.

A Lei de Execução Penal indica que o exame criminológico é obrigatório para o condenado que iniciar o cumprimento da pena em regime fechado (art. $8^{\circ}$, caput), mas considera facultativo o exame para o condenado em regime semiaberto (art. $8^{\circ}, \S$ único).

Sobre essa divergência, Hênio Azevedo de Queiroz (1982, p. 736-737) considera que o melhor critério a ser adotado é submeter todo condenado à realização do exame, com o objetivo de melhor conhecimento de sua personalidade com vistas à etiologia do comportamento criminoso, para definir regime inicial e tratamento adequado. $\mathrm{O}$ autor defende que o quantitativo da pena deve ser desprezado para efeito da individualização da execução função da periculosidade ou não do agente verificada através do exame criminológico. Para ilustrar esse pensamento, ele indica que os homicidas são os que sofrem penas de maior duração, ficando quase sempre submetidos a regime fechado, mas geralmente são que apresentam melhor conduta carcerária, maior possibilidade de reintegração e menores índices de reincidência. Ao passo que os traficantes de drogas e os praticantes de crimes contra o patrimônio são condenados a sanções mais curtas, geralmente executadas em regime semiaberto ou aberto, e, no entanto, são os que apresentam os maiores índices de reincidência. 
Nessa sistemática, consideramos que o mais indicado é submeter todo condenado ao exame criminológico, independente do regime inicialmente determinado na sentença e da duração total de sua pena. O exame é fundamental para a determinação da periculosidade do agente, que é a justificativa maior para sua permanência na prisão conforme os preceitos do Direito Penal da culpabilidade.

De acordo com a Lei de Execução Penal, o exame criminológico deverá ser realizado no Centro de Observação (art. 96 caput), ou pela Comissão Técnica de Classificação, caso aquele não exista (art. 98). Na sua realização devem participar profissionais das áreas de medicina clinica e psiquiátrica, de psicologia e de sociologia, todos com objetivo comum de revelar e estudar os aspectos estruturais, funcionais e racionais que determinam a personalidade do agente e estabelecer, a partir daí, o diagnostico e o prognóstico criminológico do condenado avaliado.

A respeito do o exame criminológico realizado por determinação legal no início da execução da pena, Alvino de Sá (2010, p. 195-196) observa que ele será mais confiável e tende a ser mais fiel enquanto avaliação da dinâmica da conduta desviante se realizado no momento mais próximo possível ao cometimento do fato típico, quando o condenado teoricamente ainda não teria se contaminado com os efeitos perniciosos da vida carcerária. Realizado dessa maneira, este diagnóstico criminológico será um importante parâmetro para as avaliações futuras do apenado. $\mathrm{O}$ autor também afirma que tal exame deve ser feito exclusivamente em benefício do preso, tem por finalidade oferecer subsídios a serem encaminhadas á Comissão Técnica de Classificação para a individualização da execução da pena e pode se restringir apenas ao diagnóstico, sendo dispensável o prognóstico criminológico.

\subsubsection{O exame criminológico nos pedidos de progressão de regime prisional}

Ao longo do cumprimento da pena, consideramos também ser de fundamental importância saber se o tratamento penal imposto ao condenado na execução está sendo adequado à sua recuperação. Nesse sistema, se faz necessária uma melhor avaliação dos aspectos referentes à sua reeducação e adaptabilidade para poder cumprir a pena em regime gradualmente menos rígido por ocasião da análise do pedido de progressão de regime prisional. Desse modo, conforme a sistemática original do art. 112 da LEP, o exame criminológico também era realizado para a instrução dos pedidos de progressão de regime e, 
juntamente com o parecer da CTC, era de fundamental importância na avaliação do mérito do condenado.

O exame criminológico, quando realizado para fins de concessão de benefícios, tem por objetivo avaliar as condições do apenado para verificar se o mesmo está apto a cumprir o restante da pena em regime menos rígido ou ter antecipada a sua liberdade por meio do livramento condicional. Sobre este exame, Alvino de Sá (2010, p. 190-191) salienta que devem ser realizados o diagnostico e o prognóstico criminológicos e os peritos da comissão interdisciplinar também devem se pronunciar a respeito da concessão ou negação do benefício.

Conforme já dissemos anteriormente, o exame criminológico é uma peça autônoma, que será analisada e apreciada pelo juiz da vara de execuções nos pedidos de progressão de regime e livramento condicional. Por ser uma espécie de laudo pericial, deve ser realizado em local adequado, ou seja, no Centro de Observação (art. 96 da LEP) e por questão de ética profissional, deve ser realizado por uma equipe multidisciplinar independente e que não esteja envolvida no acompanhamento diário das atividades do interno.

Observamos que os resultados revelados pelo exame criminológico são baseados em critérios técnicos multidisciplinares, alguns deles carregados de subjetividade. Por esse motivo, laudos e avaliações psicológicas sobre a personalidade do condenado sempre foram alvo de intensa crítica por uma parte da doutrina especializada. Desse modo, no tópico a seguir passaremos a apresentar algumas objeções levantadas contra o exame criminológico e fazer críticas e comentários a respeito delas.

\subsection{Problemas e limites do exame criminológico}

Sérgio Pitombo (1984) já salientava há muito tempo que "costuma-se levantar conhecida objeção aos pareceres periciais criminológicos". Ele observa que os críticos dos laudos e pareceres criminológicos apontam que “inexistem equipes interdisciplinares disponíveis; não há estabelecimentos próprios; nem aparelhamento para afeiçoá-los em muitas comarcas”, porém todos eles costumam "queixar-se da correção difícil 
do sentenciado e da reincidência potencial ou atual, deslembrados de que a questão acha-se na concreta individualização executória".

Conforme observado, é muito fácil criticar e reclamar do que não vem dando o resultado desejado. No entanto, críticas vazias e de cunho puramente ideológicas não podem simplesmente serem aceitas sem refutação. Quanto às objeções levantadas contra o exame criminológico, Alvino de Sá (2010, p. 197) salienta para a inconsistência de algumas delas, pois, segundo ele, possuem cunho predominantemente 'ideológico' e não se fundam em "substrato técnico". Ele considera que algumas criticas contra o exame criminológico não passam de "chavões", que por serem repetidos continuamente tornam-se "verdades". Dentre elas, Alvino de Sá destaca que são precárias as afirmações de que:

- “o exame criminológico é marcado por subjetivismo, é um tiro no escuro, não tem validade, não é confiável, pois, não existe bola de cristal que nos possibilite adivinhar o futuro" (2010, p. 197);

- “o exame parte de um pressuposto positivista, de uma concepção ontológica de crime e de uma relação intrínseca entre o condenado e o crime” (2010, p. 199);

- "é um absurdo pretender-se avaliar a periculosidade de alguém" (2010, p. 200);

- "o exame criminológico é uma invasão à privacidade e intimidade do outro" (2010, p. 200).

Ao refutar as críticas quanto à alegada "subjetividade" do exame criminológico, Alvino de Sá (2010, p. 198) observa que afirmar que o mesmo "é imprestável, por seu caráter de subjetivismo, devendo a decisão judicial pautar-se unicamente nos chamados critérios objetivos, ou seja, o lapso temporal e a conduta carcerária, é querer enxergar a objetividade e segurança onde elas também não existem". Ele critica os critérios objetivos definidos na LEP, pois em sua visão a avaliação da conduta prisional como boa e o lapso temporal não são garantias de que o apenado está preparado para a progressão. Para ele, não há explicação cientifica para se adotar um sexto da pena como o lapso temporal necessário para se conceder a progressão de regime, e pergunta: “e por que não um quarto? E porque não um décimo? Existe garantia de que, com um sexto, o apenado está preparado para a promoção?" (SÁ, 2010, p. 198) 
A respeito da avaliação de conduta, Alvino de Sá (2010, p. 198) considera que afirmar que determinado preso tem boa conduta significa apenas dizer que este condenado não infringiu nenhuma norma do regulamento, de acordo com as informações do Diretor do estabelecimento penitenciário. Ele observa que os presos conhecidos como "cadeeiros" e que exercem liderança sobre os demais não são costumeiramente punidos por faltas disciplinares. Estes presos exercem uma forma de comando paralelo sobre parte "mais frágil" da massa carcerária e os obrigam a praticar crimes e/ou a assumir a responsabilidade pelas faltas disciplinares. Desse modo, quando há uma falta, ela geralmente recai sobre esses presos "mais frágeis", os quais "continuarão a purgar sua cadeia" enquanto que os "cadeeiros" acabam por se beneficiar da progressão de regime.

O autor também salienta que, mesmo que o Diretor saiba com certeza quem são os verdadeiros "cadeeiros", ele não poderá agravar a avaliação da conduta a partir de "seu saber penitenciário". Assim, ele afirma que se o diretor se utilizasse desse "saber" passaríamos a ter como critério objetivo para a progressão o "saber penitenciário do diretor" e não mais a avaliação da boa conduta carcerária. Por fim, Alvino de Sá (2010, p. 198) questiona "onde está a objetividade de tudo isso?"

Ao refutar a objeção de que o exame criminológico é realizado "a partir de um pressuposto positivista", Alvino de Sá (2010, p. 199) salienta que o verdadeiro pressuposto básico do exame é que "existe uma relação entre as suas condições pessoais (históricas, familiares, sociais, psicológicas ou até mesmo orgânicas, não necessariamente e nem igualmente todas) e seu comportamento que o direito penal tipifica como crime". O exame então procura diagnosticar a influência de cada um desses fatores na dinâmica criminal para subsidiar a CTC na proposição das medidas recuperadoras individualizadas, pois somente assim é possível ajustar melhor os estágios de execução da pena às particularidades e antecedentes do apenado.

Quanto à possibilidade de avaliação da periculosidade do condenado por meio do exame criminológico, Alvino de Sá (2010, p. 200) salienta que não podemos confundir o exame criminológico com o exame de sanidade mental ou com um parecer de cessação de periculosidade. Para ele, é um erro crasso o técnico responsável pela confecção do exame criminológico apresentar a sua conclusão em termos de periculosidade do examinando. 
Por fim, ao refutar a afirmação de que o exame criminológico é uma “invasão à privacidade e intimidade à pessoa" do condenado, Alvino de Sá (2010, p. 200) afirma que, inicialmente, o interno deve ser cientificado que não é obrigado a se submeter ao exame criminológico e também deve ser informado de que tudo que fizer ou disser durante a realização do mesmo poderá ser usado em seu desfavor. Para o autor o que deve ser combatido é a prática de fazer o interno aceitar a se submeter ao exame com receio de que sua negação seja utilizada pelo técnico como argumento contra a concessão do beneficio pleiteado.

Por outro lado, Alvino de Sá (2010, p. 197) salienta que o exame criminológico enfrenta um conjunto de críticas realmente sérias, que possuem um substrato técnico, e não ideológico e se referem principalmente aos exame destinado á instrução de pedidos de benefícios legais como a progressão de regime e livramento condicional.

Quanto ao núcleo diagnóstico, o principal problema apontado por ele seria como poderíamos "garantir que as características psicológicas apontadas no atual exame estavam presentes quando da prática criminosa, há dois, três, ou mais anos atrás? [...] e como garantir que elas foram fatores psicológicos motivadores do crime?" (SÀ, 2010, p. 201).

Já com relação ao prognóstico e à conclusão do exame criminológico sobre a probabilidade de reincidência por parte do condenado, o autor afirma que a garantia de validade do prognostico criminológico é prejudicada em razão de que "algumas das características psicológicas comumente levantadas e tidas com particularmente relevantes costumam ser estáveis. Alem disso, os dados do passado são irremovíveis” (SÁ, 2010, p. 203).

Podemos notar que o exame criminológico é um procedimento realizado com objetivo de levantar informações constitutivas e subjetivas para subsidiar a CTC na propositura do programa individualizador no inicio da execução e também era realizado no momento de concessão de benefícios para informar o magistrado a respeito das condições gerais do apenado de passar a cumprir sua pena em regime de menor restrição ou em liberdade condicional. Desse modo, consideramos que, apesar das diversas críticas e limitações apresentadas pelo exame criminológico e de demais avaliações de cunho psicológico previstas pela sistemática original da Lei de Execução Penal, é que será possível 
se trilhar um caminho rumo a uma melhor individualização da execução da pena privativa de liberdade.

Alvino de Sá (2010, p. 210-211) indica que a realização das três avaliações (exame criminológico, exame de personalidade e parecer da Comissão Técnica de Classificação), respeitadas a especificidade e particularidades de cada uma delas, é de fundamental importância para a implantação mais eficiente dos regimes progressivos de cumprimento da pena em conformidade com critérios mais técnicos e mais científicos e com consequentemente otimização da eficácia da pena privativa de liberdade imposta ao condenado.

No próximo capitulo do texto passamos a tratar das modificações introduzidas pela Lei 10.792/2003 nos requisitos de natureza subjetiva a serem cumpridos pelo condenado e que vieram por extinguir a obrigatoriedade do exame criminológico e do parecer da Comissão Técnica de Classificação para a concessão da progressão de regime de execução da pena. 


\section{A PROGRESSÃO DE REGIME APÓS A LEI 10.792/2003: A AVALIAÇÃO DOS CRITÉRIOS SUBJETIVOS E O EXAME CRIMINOLÓGICO}

\subsection{Os novos critérios subjetivos para a progressão e as novas atribuições da Comissão Técnica de Classificação}

Em $1^{\circ}$ de dezembro de 2003, editou-se a Lei 10.792 que instituiu modificações em alguns institutos da Lei de Execução Penal e do Código de Processo Penal e regulamentou alguns pontos referentes ao Regime Disciplinar Diferenciado (RDD). Este diploma legal procurou enrijecer as regras da execução penal para alguns condenados mais perigosos e/ou membros de organizações criminosas através da possibilidade de execução de sua pena em regime disciplinar diferenciado, mas simultaneamente também procurou dar maior fluência à progressão dos regimes prisionais para a maioria dos demais internos com o fim da obrigatoriedade do exame criminológico e dos pareceres da Comissão Técnica de Classificação.

René Ariel Dotti (2009) é um dos autores que também criticou a modificação pontual de alguns institutos da Lei de Execução Penal introduzida pela Lei 10.792/2003. Para ele, a edição de tal diploma legal representou um momento de "anomalia legislativa", principalmente no que tange á modificação do art. 52 da LEP com a instituição do regime disciplinar diferenciado (RDD), batizado por ele de "Regime Da Desesperança", o que representa uma "autêntica expressão moral e material do triunfo, nesse domínio, da doutrina totalitária do direito penal do inimigo."

No escopo deste trabalho, não teceremos maiores comentários á instituição do Regime Disciplinar Diferenciado. Em nossa abordagem, nos limitaremos a destacar e comentar as modificações introduzidas pela Lei 10.792/2003 no procedimento de progressão de regime em razão da modificação na redação dos artigos $6^{\circ}$ e 112 da Lei de Execução Penal, que a partir de $1^{\circ}$ de dezembro de 2003 passaram a vigorar com a seguinte redação, in verbis: 
"Art. $6^{\circ}$. A classificação será feita por Comissão Técnica de Classificação que elaborará o programa individualizador da pena privativa de liberdade adequada ao condenado ou preso provisório."

"Art. 112. A pena privativa de liberdade será executada em forma progressiva com a transferência para regime menos rigoroso, a ser determinada pelo juiz, quando o preso tiver cumprido ao menos um sexto da pena no regime anterior e ostentar bom comportamento carcerário, comprovado pelo diretor do estabelecimento, respeitadas as normas que vedam a progressão.

$\S 1^{\circ}$ A decisão será sempre motivada e precedida de manifestação do Ministério Público e do defensor.

$\S 2^{\circ}$ Idêntico procedimento será adotado na concessão de livramento condicional, indulto e comutação de penas, respeitados os prazos previstos nas normas vigentes."

As modificações introduzidas pela Lei 10.792/2003 são, em nossa visão, incoerentes como o modelo progressivo baseado no "mérito" do condenado, instituído pela Reforma Penal e previsto também no $\S 2^{\circ}$ do art. 33 do Código Penal que não foi modificado. No caso da modificação dos critérios para a progressão de regime prisional, a referida alteração procurou dar fluência ao sistema instituído, mas o fez de um modo completamente incoerente. A extirpação da avaliação meritória com o fim da obrigatoriedade do exame criminológico e do parecer da CTC desvirtuou o sistema implementado pela Reforma Penal de 1984, uma vez que o principal pilar do sistema de execução progressiva da pena era a avaliação do mérito do condenado durante a execução da pena imposta, o qual teria sua liberdade gradativamente restabelecida conforme seu esforço pessoal demonstrado durante a execução da pena.

Em comparação com sua redação original, o caput do artigo 112 da Lei de Execução Penal deixa de fazer referencia explicita à avaliação do "mérito" do condenado como requisito subjetivo necessário para a progressão de regime. Agora, a LEP passa a indicar como requisito subjetivo apenas que o condenado apresente "bom comportamento carcerário" comprovado pelo Diretor do estabelecimento prisional onde encontrar-se recolhido. O parágrafo único do referido artigo também foi alterado e transformado em dois parágrafos. Com a nova redação, deixa-se de exigir a obrigatoriedade do parecer da Comissão Técnica de Classificação e do exame criminológico nos procedimentos de progressão de regime e passa-se a prever expressamente a manifestação do Ministério Público e do defensor. 
O requisito temporal, no entanto, permaneceu o mesmo da antiga redação, ou seja, o cumprimento mínimo de $1 / 6$ (um sexto) da pena no regime anterior ${ }^{10}$.

J. B. Torres De Albuquerque (2004, p. 47) observa que a modificação no procedimento de progressão da pena introduzida pela Lei 10.792/2003 “eliminou a realização de avaliações pelas Comissões Técnicas de Classificação e o exame criminológico, além de introduzir o contraditório, a partir da manifestação do defensor, antes do deferimento das aludidas benesses".

Já com relação à nova redação do art. $6^{\circ}$ da LEP, as funções da Comissão Técnica de Classificação foram reduzidas. Assim, elas deixam de ter a atribuição de propor progressões e regressões dos regimes e conversões e passam somente a serem responsáveis pela realização da classificação do interno e elaboração do programa individualizador de execução da pena.

Em relação aos fatores que levaram o legislador a suprimir a realização do exame criminológico para a avaliação subjetiva do condenado na ocasião da progressão do regime de execução, Rodrigo Iennaco de Moraes (2004) considera que a classificação do condenado e o exame criminológico foram previsões legais que se frustraram ao longo do tempo no modelo penitenciário brasileiro. Observa o autor que o primeiro motivo para isso é que muitos presos definitivos ainda permanecem encarcerados em estabelecimentos inadequados, destinados a presos provisórios, em cadeias publicas, ou mesmo sob a custódia da Polícia, locais onde não há aparato técnico suficiente para a realização dos exames interdisciplinares. Ele continua sua explanação salientando que na pratica forense costumavase argumentar que os dados relacionados à personalidade, ao caráter e aos valores dos condenados revelados pelo exame eram carregados de subjetividade e não poderiam servir de critério para indeferimento de "direitos públicos subjetivos". Por fim, o autor observa que são necessários investimentos de recursos estatais no âmbito do sistema penitenciário para a formação de um saber criminológico (do ponto de vista social, assistencial ou psicológico) e cujos resultados não podem ser quantificados de maneira imediata no curto prazo.

\footnotetext{
${ }^{10}$ Observamos novamente que os condenados por crimes hediondos e equiparados devem cumprir o lapso temporal prescrito no $\S 2^{\circ}$ da Lei 8072/1990 (com redação dada pela Lei 11.464/2007).
} 
Depois de discutidos os problemas apresentados pelo exame criminológico e de apresentados os novos critérios subjetivos para a progressão, passamos então a analisar como o assunto referente à possibilidade de utilização do exame criminológico para instrução dos pedidos de progressão vem sendo tratado pela doutrina e jurisprudência após a vigência da Lei 10.792/2003.

\subsection{Posicionamentos doutrinários a respeito do exame criminológico na análise dos pedidos de progressão de regime prisional}

Ao buscar referências na literatura e na jurisprudência para subsidiar o desenvolvimento desse trabalho pudemos identificar, na vigência da nova redação do artigo 112 da LEP, duas correntes divergentes a respeito da possibilidade de se utilizar o exame criminológico para subsidiar a análise do requisito subjetivo do apenado nos pedidos de progressão de regime de execução de sua pena.

Podemos considerar, por meio de uma leitura rápida e isolada do caput do atual artigo 112 da LEP, que a avaliação do mérito do condenado durante a fase de execução da pena, que era subsidiada por laudos e exames psicológicos, como o exame criminológico e o parecer da Comissão Técnica de Classificação, não é mais elencada expressamente entre os requisitos necessários para a progressão. Sob tal ótica, a exigência desses laudos pode constituir violação ao princípio da reserva legal e pode ser vista como forma de constrangimento ilegal por parte da autoridade que condicionar a progressão à realização de tais exames. Este é o posicionamento da primeira corrente doutrinaria e jurisprudencial ${ }^{11}$ que defende que os requisitos a serem cumpridos pelo apenado para a progressão do regime prisional resumem-se somente ao lapso temporal e ao bom comportamento carcerário atestado pelo diretor do estabelecimento penitenciário.

Por outro lado, há também outra corrente divergente desse posicionamento que defende a realização do exame criminológico como subsídio para que o Magistrado possa

\footnotetext{
${ }^{11}$ Neste sentido podemos citar os autores Luiz Flávio Gomes, Patrícia Donati Almeida e Elisa Maria Rudge Ramos. No STF podemos destacar o posicionamento do Ministro Marco Aurélio de Mello e o HC 85688/PR. Já no STJ podemos destacar o HC 52230/SP, o AgR no HC 51249/DF, e o REsp 828324/RS.
} 
melhor avaliar os requisitos subjetivos do condenado postulante à progressão para um regime prisional mais brando ou ao livramento condicional ${ }^{12}$. Neste caso, as peculiaridades do caso concreto indicariam a necessidade ou não da realização do exame criminológico.

Rodrigo Iennaco de Moraes (2004) observa algumas decorrências do fim da obrigatoriedade da realização do exame criminológico nos pedidos de progressão de regime. Para ele, ao mesmo passo em que se suprimiu "a possibilidade de superação do comportamentalismo como única fonte de conhecimento do comportamento no cárcere, empobreceu-se o discurso criminológico", e "declarou-se a falência de uma empresa que nunca foi posta em atividade produtiva" (MORAES, 2004). O autor indica que, ao pretenderse realizar o exame criminológico para a instrução de pedidos de progressão de regime, poderemos em breve nos deparar com alguns problemas de caráter técnico e jurídico. $\mathrm{O}$ primeiro questionamento a ser feito é se o Juiz poderia, com base em exame cuja previsão de realização foi extirpada do texto legal, negar a concessão de benefícios como a progressão de regime ou o livramento condicional. Outro problema seria como garantir que haverá na estrutura do sistema prisional, dentro em breve, profissionais qualificados para realizarem o exame criminológico.

Passamos então a discutir cada um dos dois posicionamentos acerca do assunto: a vedação completa à realização dos exames psicológicos ou a admissibilidade de avaliação desses exames nos casos de progressão do regime de execução da pena. Desse modo, o principal problema a ser tratado a partir de agora será analisar como atualmente são avaliados os requisitos subjetivos do condenado no momento da concessão ou negação do pedido de progressão de regime prisional após a edição da Lei 10.792/2003, que deixou de prever explicitamente a avaliação do mérito do condenado por meio das informações levantadas pelo exame criminológico e com base no parecer da Comissão Técnica de Classificação.

Uma corrente doutrinária considera que a redação atual do artigo 112 da LEP aboliu por completo a realização dos laudos psicológicos (exame criminológico e parecer da CTC) como forma de subsidiar o Juiz na avaliação do cumprimento dos requisitos

\footnotetext{
${ }^{12}$ Neste sentido podemos citar os seguintes autores: Marcus Vinícius Feltrim Aquotti, Bruna Fernandes Pinatto, Rodrigo Iennaco de Moraes dentre outros.. No STF podemos destacar o HC 88052/DF, o Informativo $\mathrm{N}^{\circ} 439$ e a Súmula Vinculante $N^{\circ}$ 26. Já no STJ podemos destacar o enunciado da Súmula 439.
} 
subjetivos do condenado nos pedidos de progressão de regime. Comparando-se a com a redação anterior notamos a supressão, na parte final do caput, da expressão "e seu mérito indicar a progressão", assim para essa parte da doutrina a orientação é no sentido de que não é mais necessária avaliação do mérito na concessão de benefícios ao apenado.

Em ensaio sobre o assunto, os autores Luiz Flávio Gomes, Patrícia Donati Almeida e Elisa Maria Rudge Ramos (2009) consideram que, após a edição da Lei 10.792/2003, a análise do aspecto subjetivo do condenado postulante à progressão de regime foi abolida da Lei de Execução Penal.

Eles observam que, mesmo considerando a natureza híbrida (penal e processual) das normas que regulamentam o Direito da Execução Penal, as modificações legislativas que beneficiam os condenados devem ter aplicação imediata, pois, mesmo obedecendo a princípios diferentes, implicam em uma mesma consequência lógica. Se considerarmos tal norma como sendo de direito material, a mesma obedecerá ao princípio da retroatividade benigna e se definirmos sua natureza como processual, ela então respeitará o princípio da incidência imediata. Dessa forma, tais autores consideram que, após $1^{\circ}$ de dezembro de 2003, independentemente do entendimento que possa ser adotado, "o exame criminológico, como requisito para a concessão da progressão de regime, foi extirpado do ordenamento jurídico brasileiro. A lei possui, portanto, incidência imediata, devendo ser eliminado o citado impedimento para a concessão da progressão de regime.” (GOMES, 2009)

Sobre o aspecto da natureza jurídica, entendemos que as normas que regulamentam o regime de execução da pena e tratam dos critérios a serem cumpridos pelo condenado para a obtenção de benefícios legais (como o comando do artigo 112 da Lei de Execução Penal) incidem diretamente sobre a satisfação do direito de punir do estado e por esse motivo possuem natureza inequivocamente penal, com aplicabilidade imediata quando mais benéficas. Esse também é o entendimento do Superior Tribunal de Justiça ${ }^{13}$.

Prosseguindo em defesa da proibição da realização dos laudos psicológicos, Luiz Flávio Gomes, Patrícia Donati Almeida e Elisa Maria Rudge Ramos (2009) chegam a

13 Nesse sentido destacamos as seguintes decisões do STJ: RESP 61.987/SP ( $6^{\circ}$ turma, Relator Ministro Adhemar Maciel, DJU. 20/05/1996); RESP 78.791/SP (6º turma, Relator Ministro Adhemar Maciel, DJU. 09/09/1996); RESP 70.882/PR (5º turma, Relator Ministro Cid Flaquer, DJU. 05/08/1996); 
considerar que a redação atual do artigo 112 da LEP não prescreve nenhum requisito de natureza subjetiva a ser cumprido pelo apenado. Para eles "os requisitos para a progressão de regime, após a Lei 10.792/2003, possuem natureza objetiva (tempo de cumprimento da pena e bom comportamento carcerário), não mais sendo possível falar na análise do mérito (requisito subjetivo) do sentenciado”. Os autores Marcus Vinícius Feltrim Aquotti e Bruna Fernandes Pinatto (2009) também falam em requisitos "puramente objetivos, já que se deixou de exigir a apreciação do mérito." Observamos então uma divergência entre esses autores citados e outros que fazem referência a este ponto específico. Os demais autores consultados são basicamente unânimes em considerar o bom comportamento carcerário como um requisito de natureza subjetiva.

Em nossa visão, considerar a avaliação do comportamento do apenado como um requisito de natureza objetiva não é o caminho mais correto. Marcelo Gomes Silva (2004, p. 184) aponta os problemas de se classificar o bom comportamento carcerário como um critério objetivo. Para ele, o primeiro equívoco aparece quando se questiona o que vem a ser o "bom comportamento carcerário" uma vez que a lei não define de forma objetiva como o Diretor deve classificar o comportamento de um apenado. Nesse particular, o autor questiona se "Poderia ele cometer falta leve, média ou grave?"; "Qual o tempo para a reabilitação do comportamento?" e também se “A falta disciplinar prescreve?" Para ele, todos esses questionamentos são deixados à avaliação subjetiva do Diretor que deve classificar o comportamento.

Observamos que, diante da nova redação do artigo 112, a Lei de Execução Penal não deixa explicito os critérios que devem ser utilizados pelo diretor do presídio para atestar o bom comportamento do interno quando há o cometimento de faltas (leves, médias ou graves) e de quando haveria prescrição de tais faltas em função de sua gravidade ${ }^{14}$. Todos

\footnotetext{
${ }^{14}$ No Paraná, a Resolução N 115, de 15/12/2003, da Secretaria de Estado da Justiça e Cidadania, regulamenta a classificação da conduta carcerária. De acordo com a resolução, apresentara "bom comportamento carcerário" o interno que não possuir anotação de falta disciplinar grave até o requerimento do benefício. (art. $2^{\circ}$ ) se o interno apresentar faltas, deve cumprir o período de reabilitação previsto no Regimento Interno. (KUEHNE, 2004a). Já em São Paulo, a Resolução SAP N ${ }^{\circ} 115$, de 4/12/2003, define os critérios para avaliação do comportamento carcerário. De acordo com seu art. $1^{\circ}$, o comportamento carcerário poderá ser classificado como "ótimo", "bom", "regular" ou "mau". "Ótimo" comportamento terá o interno que não cometer nenhuma falta disciplinar desde seu ingresso na prisão e ainda possuir elogios em seu prontuário (Art. $2^{\circ}$ ). Terá "bom" comportamento quem não cometer falta disciplinar (art. $3^{\circ}$ ). $\mathrm{O}$ interno que praticar faltas, mas cumprir o período de reabilitação de conduta terá seu comportamento equiparado a "bom". Enquanto não cumprir a reabilitação da conduta, terá comportamento classificado como "regular" quando houver registro de falta média e/ou leve (art. 4") ou "mau"
} 
estes critérios ficam sujeitos à valoração subjetiva do diretor do estabelecimento. A Lei de Execução Penal prevê sanções apenas para o cometimento de falta grave, são elas: a revogação da autorização de trabalho externo (art. 37, § único); regressão de regime (art. 118); revogação das saídas temporárias (art. 125); e perda dos dias remidos (art. 127). A regulamentação das demais faltas deve se feita por legislação complementar estadual ou regional, assim não temos como garantir que esta regulamentação será feita de maneira objetiva ou subjetiva.

Maurício Kuehne (2004a) observa que, no momento da edição da Lei 10.792/2003, algumas Unidades da Federação ainda não possuíam regulamentos disciplinares penitenciários estabelecendo as faltas leves e médias ${ }^{15}$. Assim, sugeria o autor que se adotasse como o critério para a expedição do atestado de bom comportamento carcerário a "não existência de falta grave, regularmente apurada, nos 12 (doze) ou, conforme a natureza do crime, 24 (vinte e quatro) meses anteriores à data da postulação do benefício (progressão, livramento condicional, etc.)". Sugeria também que o processo administrativo disciplinar não fosse óbice à postulação do beneficio, mas que a decisão final ficasse vinculada ao resultado apurado no procedimento administrativo. O autor (KUEHNE, 2004b, p. 309) considera que a melhor solução teria sido a aprovação das regras para a classificação da conduta carcerária propostas no Projeto 5075/2001 ${ }^{16}$, o qual foi inclusive submetido á apreciação do Conselho

quando constar-se o assentamento de falta grave (Art. $5^{\circ}$ ). A resolução ainda proíbe a avaliação do mérito ou do comportamento com base no resultado do exame criminológico, o qual deve ser considerado apenas para a classificação, individualização e acompanhamento da execução da pena (KUEHNE, 2004a). No Distrito Federal, o Regimento Interno dos Estabelecimentos Penais (RIEP), instituído pela portaria $\mathrm{N}^{\circ} 001$ de 11/01/1988 da Secretaria de Segurança Pública, indica que a classificação do interno será realizada com base no comportamento e no desempenho no trabalho. O Regimento prevê três graus de classificação para o comportamento: "bom", "regular" ou "mau" (art. 40). Também prevê que a prática de faltas disciplinares implicará em desclassificação e retorno ao grau inferior (art. 41) e que o período mínimo para reclassificação do comportamento será de seis meses.

${ }^{15}$ No Distrito Federal as faltas disciplinares de natureza leve e média são definidas respectivamente nos artigos 119 e 120 do Regimento Interno dos Estabelecimentos Penais (RIEP).

${ }^{16}$ O projeto de Lei 5075/2001 apresentado no livro do professor Maurício Kuehne (2004b, p. 309-311) propunha que se fossem adicionados à LEP os artigos 52-A a 52-D, para definir as regras para a classificação da conduta penitenciária e disciplinar o instituto da prescrição das faltas disciplinares. Pelo projeto, a Lei de Execução Penal passaria a vigorar com a seguinte redação:

“Art. 52-A. A conduta será classificada como:

I - boa, quando não existir punição por falta média ou grave;

II - regular, quando houver punição por falta média; e

III - má, quando houver punição por falta grave.

$\S 1^{\circ}$ A terceira punição por falta leve, no prazo de 6 (seis) meses, considerar-se-á falta média.

$\S 2^{\circ}$ A terceira punição por falta média, no prazo de 1 (um) ano, considerar-se-á falta grave. 
Nacional de Política Criminal e Penitenciária (CNPCP). Para ele, com a edição dos acréscimos passaríamos a ter definidos na Lei de Execução Penal os critérios uniformes para classificação da conduta (como “boa”, "regular' ou “má”), a regulamentação do instituto da prescrição das faltas disciplinares e ainda as regras para a reclassificação da conduta do condenado, esta ultima considerada pelo autor como uma "medida salutar, possibilitando a reabilitação do preso, advindo, de tal situação, reflexos no exame do requisito subjetivo à outorga dos benefícios (direitos) previstos em Lei” (KUEHNE, 2004b, p. 310).

Outra questão importante observada por Maurício Kuehne (2004a) referente à avaliação comportamental do interno diz respeito à dificuldade de será definir como apurar o comportamento dos condenados recolhidos em cadeias públicas e distritos policiais. Nestes casos, ele afirma que a aferição do comportamento deverá ser realizada pelo responsável pela custodia do preso (Delegado, Carcereiro, etc.), onde geralmente não há estrutura adequada para a apuração das faltas disciplinares. Desse modo, não poderíamos "aceitar atestados, v.g. que façam constar mau comportamento, se não houve procedimento específico à sua apuração?"

Outro problema que também apontamos é que a avaliação do comportamento do condenado é realizada durante um período em que o mesmo encontra-se submetido a um rígido controle e supervisão pelo estado e seus agentes e também sujeito a uma forma de controle informal, imposta a ele pelo próprio ambiente prisional e pela convivência com os demais internos. Não temos como garantir que o condenado, agraciado com a progressão por se enquadrar a essas regras impostas a ele, continuará a manter o bom

Art. 52-B. A reclassificação da conduta, de regular para boa, dependerá da inexistência de punição por falta disciplinar média, durante o período de 6 (seis) meses, observado o disposto nos parágrafos $1^{\circ}$ e $2^{\circ}$ do art. 52-A.

Art. 52-C. A reclassificação da conduta, de má para regular, dependerá da inexistência de punição disciplinar por:

I - falta grave prevista no artigo 50, incisos I, II e III, desta Lei, no prazo de 2 (dois) anos;

II - qualquer outra falta grave, ou por 3 (três) faltas médias, no prazo de 1 (um) ano. (NR)

Art. 52-D. Prescreve a falta disciplinar, para o fim do art. 59 desta Lei, nos seguintes prazos:

I - em 1 (um) ano, da falta grave;

II - em 6 (seis) meses, da falta média;

III - em 3 (três) meses, da falta leve.

$\S 1^{\circ}$ O prazo da prescrição começa a correr a partir do conhecimento da infração e sua autoria, pela Administração;

$\S 2^{\circ}$ Em iguais prazos prescrevem as sanções disciplinares, que impostas não venham a ser executadas. $\S 3^{\circ}$ Não corre a prescrição da falta disciplinar, enquanto o condenado estiver foragido." 
comportamento apresentado no período anterior quando sujeito a um regime menos rígido de vigilância ou ainda quando estiver em liberdade condicional.

Sobre este aspecto, Rodrigo Iennaco de Moraes (2004) muito bem observa que "o bom comportamento carcerário pode representar adaptação às regras da prisão, que se distanciariam gradativamente das regras do convívio social em liberdade”. Para ele, a supressão do exame criminológico vem reafirmar a supervalorização pragmática da abordagem comportamentalista, o que "representa obstáculo à efetivação do ideal ressocializador da pena, haja vista que a exteriorização do comportamento carcerário, submetido a regras dessocializadoras, não corresponde ao comportamento que se espera, em liberdade, do condenado".

Concordamos plenamente como este posicionamento, uma vez que eu pude vivenciar na prática essa situação durante os mais de sete anos (entre 2002 e 2009) em que trabalhei no Centro de Internamento e Reeducação (CIR) do Sistema Penitenciário do Distrito Federal. Nesse período, pude observar que praticamente todos os internos ali recolhidos apresentavam conduta prisional compatível com as normas de comportamento prescritas pela administração do sistema penitenciário quando estavam sob a vigilância direta dos agentes estatais. No entanto, tive oportunidade de observar por inúmeras vezes que muitos desses internos sediam a pressão dos demais internos e demonstravam outro tipo de comportamento (anti-social, marginal, compatível com os (des)valores dos demais membros daquela comunidade) nos momentos que não estavam sob observação direta.

Ainda com relação à avaliação do comportamento do interno, destacamos a observação apontada por Bruna Fernandes Pinatto e Marcus Vinícius Feltrim Aquotti (2009) sobre o atestado de boa conduta carcerária emitido pela administração penitenciária. Estes autores salientam que, ao atestar a boa conduta carcerária, o Diretor do estabelecimento prisional "provavelmente não acompanhará a evolução ou regressão do condenado, e mesmo que o faça, pouco demonstra em relação a sua periculosidade ou possibilidade de reincidência". Para os autores, a submissão do condenado às regras do regime carcerário impostas durante o período de execução da pena "nada dizem a respeito da recuperação, são seguidas por uma questão de sobrevivência". 
Sergio Pitombo (1999) também observava que a análise dos requisitos subjetivos referentes ao mérito do condenado jamais poderia se resumir a aspectos objetivos do comportamento exterior do interno. Ele afirmava que, durante a execução da pena, "o proceder mostra a dupla face, ao mesmo tempo, ou não. [...] $\mathrm{O}$ positivo e o negativo despontam, no correr da vivência prisional do condenado. Cuidam-se, portanto, de valores do comportamento; porém, não se resumindo na disciplina, jamais.”

Limitar a avaliação dos aspectos subjetivos do condenado à avaliação de disciplina é perigoso e por isso ela não deve ser tomada como o único referencial para avaliar o grau de recuperação do condenado. Conforme já observamos, no ambiente prisional, o interno além de se sujeitar ao cumprimento de regras estatais compulsórias também é submetido a pressões dos outros internos ou ainda poderá ser coagido por organizações criminosas que exercem uma espécie de poder paralelo no interior desse ambiente. Assim, a avaliação baseada única e exclusivamente no comportamento somente demonstra a adaptação do interno às regras do ambiente prisional e nada diz respeito à sua recuperação. $\mathrm{O}$ interno que comete uma falta muitas vezes o faz não por vontade própria, mas sim por pressão dos demais e muitas vezes o faz por uma questão de sobrevivência dentro daquele ambiente.

Luiz Flávio Gomes, Patrícia Donati Almeida e Elisa Maria Rudge Ramos (2009) consideram que "a progressão de regime não é prêmio, muito menos, recompensa pelo mérito do condenado. Este não precisa demonstrar arrependimento, conformismo ou mudança no caráter e personalidade". Para eles a progressão de regime é um direito subjetivo do condenado que cumpriu os requisitos previstos no caput do art. 112 da LEP (lapso temporal e bom comportamento carcerário) e afirmam que a atual legislação brasileira não exige avaliações de cunho psicológico para concessão de progressão de regime. Desse modo, a negação da progressão de regime ao condenado que cumpriu os requisitos objetivos estabelecidos em lei com base em resultado desfavorável de um eventual exame criminológico constitui uma forma de coação ilegal sujeita a habeas corpus. Por fim, estes autores oportunamente observam que a eventual realização do exame criminológico não deve vincular a decisão do Juiz, que poderá discordar do posicionamento dos peritos se o fizer de maneira motivada.

O professor Rogério Lauria Tucci (1988, p. 274) é outro autor que também considera que a progressão de regime prisional foi originalmente concebida Lei de Execução 
Penal como um direito subjetivo do condenado que cumpriu os requisitos em referência, neste caso o lapso temporal e o "mérito" (requisitos objetivos e subjetivos). Quanto ao aspecto comportamental, ele observa que, para fins de progressão de regime, somente se avaliará o comportamento do condenado apresentado após de iniciada a execução da pena, uma vez que "não constitui requisito objetivo da progressão a reprovabilidade maior ou menor da conduta do agente, ao praticar a infração penal”. Observa também que a reprovabilidade da conduta do agente já foi aferida pelo Juiz no momento de definição do tipo e da quantidade de pena a ser aplicada, reforçando assim a autonomia dos momentos de aplicação e de execução da pena imposta.

Outro aspecto muito questionado pelos doutrinadores que criticam negativamente as modificações introduzidas pela Lei 10.792/2003 diz respeito à transferência do poder de decisão acerca da progressão de regime. Para eles esta decisão passa a ser efetivamente realizada administrativamente pelo diretor do presídio por meio do atestado conduta carcerária.

Lenio Luiz Streck e Roberto Bandeira Pereira (2006) consideram que, de acordo com a atual redação do artigo 112 da Lei de Execução Penal, transferiu-se o poder de aplicar o Direito para a área administrativa. Eles ressaltam que "a alteração legislativa acabou por transformar o juiz das execuções em mero homologador de laudos - visto que lhe basta verificar o requisito objetivo (tempo) e a existência de atestados de boa conduta carcerária -, violando o princípio da reserva de jurisdição". Para eles, a alteração legislativa está em rota de colisão com o sistema jurisdicional previsto pela LEP, pois vincula a decisão do juiz ao teor dos atestados do diretor do estabelecimento penitenciário, o que acaba por "administrativizar a execução".

Consideramos que uma vez proibido de avaliar o mérito, o Juiz da execução terá seu papel relegado ao de um mero homologador do atestado de boa conduta carcerária emitido pela administração penitenciária, assim a real decisão a respeito da progressão é transferida da esfera judicial para a esfera administrativa. Este posicionamento não é o mais correto, pois contraria outros comandos legais como o artigo 194 da LEP, cujo texto prevê que "o procedimento correspondente às situações previstas nesta Lei será judicial, desenvolvendo-se perante o Juízo da execução" e também é um flagrante desrespeito ao 
principio da jurisdicionalização do Direito da Execução Penal, proposto no item 92 da sua exposição motivos (In: RANGEL, 1983, p. 73).

Diversos autores defendem que a alteração legislativa introduzida no artigo 112 da Lei de Execução Penal não proibiu a realização do exame criminológico, mas apenas afastou a sua obrigatoriedade. Para nós, este posicionamento é mais coerente com o sistema instituído pela Reforma Penal de 1984. Para essa corrente doutrinária, o Direito brasileiro ainda admite nos pedidos de progressão de regime a análise do mérito com base nas conclusões do exame criminológico e nos pareceres da Comissão Técnica de Classificação, mesmo diante da atual redação do artigo 112 da LEP. Esses autores consideram que o referido artigo não obriga, mas também não proíbe por completo a realização do exame criminológico para instrução dos pedidos de progressão de regime prisional. Para eles, as peculiaridades do caso concreto justificam a realização do referido exame para alguns condenados.

Alípio Silveira (1965, p. 58) atenta para a importância de melhor se avaliar outros aspectos da personalidade do apenado na ocasião de concessão de benefícios. Nesse sentido, escreve que um tratamento penal racional deve ser baseado na personalidade do sentenciado e considera que não "seria admissível remover o sentenciado para estabelecimento penal aberto, ou conceder-lhe livramento condicional sem que antes se tenha aferido sua periculosidade”. Para ele essa avaliação deve considerar o lado psicológico do apenado e não pode ser baseada apenas em avaliação de comportamento, pois este é um “índice muitas vezes falível”.

Ao destacar a importância do Exame Criminológico na individualização executória da pena, Bruna Fernandes Pinatto e Marcus Vinícius Feltrim Aquotti (2009) observam que a criminologia evoluiu com a preocupação de estudar o criminoso e que tal estudo sempre se deu através do exame criminológico. Eles consideram que o exame, além de ser importante instrumento de individualização executiva e de servir de subsidio para os juízes na concessão da progressão, ainda pode apontar as razões para o delinquente ter praticado o crime e também pode ser usado como subsidio a implantação de medidas preventivas de combate à criminalidade. No entanto, admitem que o exame criminológico foi dispensado para efeito de concessão de progressão, mas advogam que "a decisão tomada pelo legislador, de não inserir na nova redação do art. 112 a realização do exame criminológico, visivelmente 
não foi acertada, visto que esse era o principal meio de se averiguar a real situação psíquica e emocional do condenado" (AQUOTTI, 2009).

René Ariel Dotti ${ }^{17}$ salienta que o dogma da individualização, baseado no princípio da classificação, é um dos pilares básicos da Reforma Penal de 1984. Consideramos, então, a observação feita por Aquotti e Pinatto (2009) muito relevante, pois, ao não mais se obrigar a avaliar as características psicológicas do apenado no momento da passagem para um regime mais brando, a atual redação do artigo 112 da LEP entra em rota de colisão com princípio da individualização e acaba por desfigurar o sistema progressivo baseado no merecimento estabelecido em 1984.

Ao discorrerem sobre a importância da realização do exame criminológico, Cláudio Leotta de Araújo e Marco Antônio de Menezes (2003) questionam a posição do legislador frente ao assunto, considerando que houve um retrocesso a partir da edição da Lei 10.792/2003. Para estes autores, o exame serve para avaliar a evolução do condenado frente á execução da pena e verificar se a pena realmente cumpriu seus fins de contribuir para a recuperação e ressocialização do mesmo. Consideram também que o Estado jogou a toalha ao admitir abolir o exame criminológico, desse modo questionam se "foi o exame criminológico ou a pena de prisão que faliu, não servindo esta para recuperar quem quer que seja, restando a ressocialização do egresso uma quimera, frente ao quadro atual?"

Para Marcelo Gomes Silva (2004, p. 189), com a adoção da Lei 10.792/2003 o estado, ao acabar com a exigência do exame criminológico para a progressão, optou pelo caminho mais cômodo. Ele observa que o poder público poderia ter atacado o problema de outro modo, investindo em treinamento do pessoal responsável pela perícia, determinando o acompanhamento psicológico do reeducando ao longo do cumprimento da pena, ou mesmo estipulando outros critérios para o exame. No entanto, o legislador preferiu retirar o exame do ordenamento jurídico e, desse modo, "ao invés de acabar com um

\footnotetext{
${ }^{17}$ Para Dotti (1982, p. 604-605), “o dogma da individualização da execução traduz um desdobramento lógico do principio da personalidade da pena". Nesse aspecto, ele considera que o principio da classificação resulta da lei e das condições pessoais do condenado e se materializa no cumprimento da pena em uma das três modalidades de regime de execução, fechado, semiaberto ou aberto, de acordo com qualidade e quantidade da pena. Por fim, assevera que a execução progressiva da pena constitui expressão dinâmica do processo de classificação e que deve ser submetida ao "indispensável controle jurisdicional".
} 
problema do sistema prisional, criou mais um" (SILVA, 2004, p. 189), pois o que temos visto desde então é um crescente aumento nos índices de violência e criminalidade.

Para Estevão Luís Lemos Jorge (2005), se avaliarmos apenas o comando do artigo 112 da LEP, “criminosos perigosos e que não possuem condições de retornar ao convívio social poderão ser postos em liberdade, surgindo, certamente, decisões no sentido de que basta o cumprimento do lapso temporal e o bom comportamento carcerário". O autor considera que essa forma de concessão de benefícios "só fomenta a certeza de impunidade, aumentando os índices de criminalidade que assolam o país.”

Dessa maneira, Estevão Luís Lemos Jorge (2005) advoga que, na avaliação dos pedidos de progressão, “o juiz deve apurar não só o critério objetivo, mas também o subjetivo (mérito de executado)". O autor considera que, diante da nova redação do artigo 112 da LEP, o Juiz não mais será obrigado ("vinculado") a determinar a realização do exame como antes ocorria, mas que agora ele passa então a ter uma maior liberalidade e poderá agilizar os pedidos, solicitando ou não o exame criminológico conforme indicarem as circunstâncias do caso concreto.

Ao realizarmos uma interpretação sistemática dos estatutos legais que regulam a execução penal no Brasil, chegamos à conclusão de que os preceitos da Lei de Execução Penal e do Código Penal, em consonância com a Constituição Federal de 1988, autorizam a análise do mérito do condenado nos pedidos de progressão de regime. Nesse sentido, Estevão Luís Lemos Jorge (2006) considera que a Lei 10.792/2003 apenas determinou o fim da obrigatoriedade da confecção do exame criminológico para "todo e qualquer executado", mas o Juiz pode determinar esses exames "quando o preso tiver praticado crime doloso com o emprego de violência ou grave ameaça à pessoa, ou seja, se houver necessidade de ser aferido o mérito do condenado para que não haja prejuízo à sociedade". Desse modo garantimos o respeito ao preceito do $\$ 2^{\circ}$ do artigo 33 do Código Penal, segundo o qual "a pena privativa de liberdade deve ser executada de forma progressiva e segundo o mérito do condenado".

J. B. Torres de Albuquerque (2004, p. 48-49) também defende que o Juiz deva determinar a realização do exame criminológico para aferir o mérito do condenado por crime doloso praticado com o emprego de violência ou grave ameaça à pessoa. Para ele, o $\S 2^{\circ}$ 
do art. 33 do CPB determina "categoricamente e de forma assaz" a observação do mérito do condenado na execução progressiva da pena. Frente a este comando legal, o juízo responsável pela execução, diante de dúvidas quanto ás reais condições pessoais do condenado de cumprir o restante da pena em regime menos rígido ou para retornar ao convívio social em liberdade "deverá na melhor forma do direito, estabelecer um condicionamento para a concessão da progressão do regime prisional, consubstanciando sua convicção ao resultado do exame criminológico. Pois, procedendo de outra forma, ocorrerá um contra-senso”.

Estevão Luís Lemos Jorge (2005) ainda considera que, ao passar a exigir apenas o lapso temporal e a boa conduta carcerária para a concessão de benefícios, a analisada alteração legislativa acaba por desrespeitar a separação e autonomia entre os poderes Judiciário e Executivo. Para ele, "não basta o atestado de conduta carcerária, expedido pela Administração Pública, para levar o Magistrado a abrir mão de sua independência funcional, não mais avaliando, de forma concreta, o progresso e o merecimento de condenados submetidos à sua jurisdição".

Desse modo, consideramos que, ao tomar sua decisão, o Juiz responsável pela execução não pode decidir com base na interpretação superficial de apenas um comando isoladamente considerado, mas deve sim considerar sistematicamente o conjunto de comandos contidos nos diplomas legais que regulamentam a matéria avaliada. Por esse motivo, Marcelo Gomes Silva (2004, p. 185) adverte que:

"O segundo engano decorrente de uma análise pura da Lei e sem a
contextualizar com a Constituição da República, Código Penal e demais
artigos da LEP, fazendo supor que o exame criminológico não seja mais
exigível para a concessão de progressão de regime. Fundamental é que se
avalie suas condições psicológicas para regresso ao convívio social, típico do
sistema de progressão adotado pelo Brasil. [...] A análise da personalidade
do sentenciado, seu grau de periculosidade, entendimento dos fins da
reprimenda, probabilidade de voltar a delinquir e sugestão de formas de
medidas necessárias ressocialização são fundamentais para a colocação do
apenado em um regime prisional mais brando.”

Consideramos que, a melhor solução para respeitar os preceitos do Direito da Execução Penal nos dias de hoje, ainda seja a de aferir o mérito do sentenciado nos pedidos de progressão de regime, uma vez que a pena é executada em um sistema progressivo que busca a reinserção gradativa do condenado ao convívio social. Assim, durante a execução 
da pena, o reeducando deve ter avaliado não somente o seu comportamento carcerário, mas também sua aptidão para cumpri-la em etapas e em regime cada vez menos rigoroso, até poder retornar ao convívio social em liberdade. Nesse modelo, só deverá progredir quem realmente apresente mérito para tal.

Nesse processo, Marcelo Gomes Silva (2004, p. 185 a 187) considera que o Juiz, ao avaliar o mérito do condenado, pode se utilizar dos laudos psicológicos e dos pareceres da Comissão Técnica de Classificação para fundamentar sua decisão sobre os pedidos de progressão, já que “o exame criminológico é uma garantia que o Estado-Juiz possui para a concessão da liberdade a um condenado. Não que o Magistrado fique adstrito ao laudo, mas lhe dá considerável suporte para a decisão" (SILVA, 2004, p. 185). Para ele, as regras do direito processual penal autorizam ao "Juiz socorrer-se de profissionais habilitados para melhor análise do apenado" (SILVA, 2004, p. 187). Assim, embora a redação atual do artigo 112 da Lei de Execução Penal não mais exija a realização do exame criminológico para a avaliação do mérito, consideramos que tanto o juízo da execução como o representante do Ministério Público podem solicitá-lo diante das peculiaridades do caso concreto.

J. B. Torres de Albuquerque (2004, p. 17) bem observa que nossa melhor doutrina indica que os princípios da isonomia e da personalização da pena também estão incluídos entre os princípios constitucionais básicos que regulam a execução penal. Ele afirma que, em respeito a princípio da isonomia (art. $5^{\circ}$, caput da CFB de 1988), não podemos dispensar o mesmo tratamento a condenados que possuam condições pessoais diversas. Assim, um apenado com bom comportamento e condição psicossocial de sair da prisão não pode ser tratado de modo idêntico àquele que apresenta bom comportamento, mas não tem nenhuma condição psicológica para retornar ao convívio social. Segundo o autor, "se interpretarmos que a avaliação da personalidade do sentenciado [...] se resume à simples análise de um atestado carcerário, estaremos dando azo ao total descumprimento do princípio constitucional da isonomia" (ALBUQUERQUE, 2004, p. 17)

Os autores Roberto Bandeira Pereira e Lenio Luiz Streck (2006), por sua vez, consideram que o atual artigo 112 da LEP só será constitucional "se não vedar a realização do exame criminológico diante das necessidades do caso concreto, podendo servir de fundamento para o deferimento ou indeferimento do pedido de progressão". Estes autores, a princípio, defendem que a alteração imposta ao texto da Lei de Execução Penal é 
inconstitucional. No entanto, admitem que uma solução alternativa possa ser manejada através da interpretação conforme a Constituição. Assim, o artigo 112 pode permanecer com sua literalidade atual, mas a norma resultante dessa interpretação, é que exsurgirá redefinida em conformidade com a Constituição, preservando, desse modo, o caráter de jurisdicional da decisão que (in)defere a progressão de regime e compatibilizando a norma com o Texto Maior.

J. B. Torres de Albuquerque (2004, p. 16) também segue essa linha de raciocínio. Ele considera que:

"a correta hermenêutica da alteração legislativa ora comentada decorre da
chamada "interpretação conforme" a Constituição Federal (art. $5^{\circ}$, caput e
inciso XLVI, que tratam dos princípios da isonomia e da individualização da
pena), bem como de uma análise sistemática dos arts. $5^{\circ}, 6^{\circ}, 8^{\circ}$ e $112, \S \S 1^{\circ}$ e
$2^{\circ}$ (com as alterações da Lei $10.792 / 2003$ ), e do art. 131 , todos da Lei de
Execução Penal, com o art. $33, \S 2^{\circ}$, e com o art. 83 , inciso III e parágrafo
único, do Código Penal".

Desse modo, este autor defende que, diante de uma situação concreta na qual fique evidenciada a periculosidade do apenado (como exemplo teríamos a violência utilizada ou a reincidência na prática criminosa) o Juiz da execução "tem o poder-dever de requisitar o laudo de exame criminológico e o parecer da CTC para fazer uma análise mais profunda da personalidade do apenado, afastando, assim, o teor do atestado de boa conduta carcerária, mesmo sob a égide da Lei 10.792/2003” (ALBUQUERQUE, 2004, p. 16-17).

Nesse mesmo sentido, Guilherme de Souza Nucci (apud, SILVA, 2004, p. 188) assevera que:

“Outra não pode ser a interpretação a ser dada, uma vez que seria fazer letra morta da riqueza proporcionada pelo art. $5^{\circ}$, XLVI, da Constituição Federal, consagrador do princípio constitucional da individualização da penal - e lei ordinária não poderia fazê-lo". [...] "Por isso, partindo-se do pressuposto de que a individualização da pena não se encerra com a prolação da sentença, continuando durante a execução da pena, que possui caráter jurisdicional, logo, depende de atos motivados do juiz para que se desenvolva, jamais se poderia considerar extinta ou afastada a possibilidade de, para formar seu convencimento, o magistrado ficar entregue a um simples atestado de boa conduta carcerária, fornecido pela direção do presídio, para todo e qualquer caso, sabe-se lá de que forma e com qual critério. O Poder Judiciário é autônomo do Executivo, não sendo um atestado o suficiente para levar o magistrado a abrir mão de sua independência funcional, avaliando concretamente o progresso e o merecimento de condenados submetidos à sua jurisdição. Outro caminho seria coibir a individualização executória da pena, o que, ademais, não seria o ideal”. 
Consideramos que esta é a melhor solução a ser apresentada para o problema em tela. Assim, sempre que for necessária a avaliação mais detalhada da personalidade do criminoso, verificada por meio das peculiaridades indicadas pelo caso concreto, o juiz poderá determinar de ofício a realização do exame criminológico e embasar sua decisão com base nas informações obtidas no laudo elaborado pelos profissionais do Centro de Observação Criminológica.

Esse também é o caminho indicado por Alvino Augusto de Sá (2010, p. 209). Para ele, "devemos reconhecer que, em determinados casos, tendo em conta a natureza e gravidade do delito cometido, os históricos criminal e prisional do examinado, há que se tomar cuidados especiais para a concessão dos benefícios legais". Nos casos mais complexos o autor recomenda que se faça o exame criminológico e que Comissão Técnica de Classificação emita o seu parecer a respeito do caso. Alvino de Sá salienta que o exame criminológico, por ser uma perícia, não seja realizado pela CTC, mas aconselha que o resultado do exame também seja encaminhado à CTC, para que a mesma possua mais subsídios para confecção de seu parecer e faça uma avaliação mais fidedigna do acompanhamento que vem fazendo do preso.

\subsection{Jurisprudência sobre a realização do exame criminológico nos pedidos de progressão de regime prisional}

\subsubsection{Jurisprudência do STF}

Inicialmente, destacamos algumas decisões do STF, em sede de progressão de regime com base no resultado do exame criminológico, proferidas antes da vigência da Lei $10.972 / 2003$.

No HC 69415/SP (relator Ministro Octavio Gallotti, julgado em 25/08/1992) os Ministros da $1^{\circ}$ turma do STF observaram que "o laudo criminológico não substitui a deliberação do Juiz, apenas colabora, tecnicamente, na formação da convicção do Magistrado". 
No HC 70549/SP (1 Turma, relator Ministro Sepúlveda Pertence, julgado em 01/03/1994) o STF considerou que a aferição dos requisitos de ordem subjetiva para progressão não podem ser avaliados na via sumaríssima do habeas corpus $^{18}$.

No acórdão do HC 71303/SP (relator Ministro Marco Aurélio, julgado em 15/08/1995), os Ministros da $2^{\circ}$ Turma salientam que o exame criminológico deve ser atual à época da decisão sobre o pedido de progressão. Neste caso, o réu é reincidente (mais de 20 condenações e pena total superior a 60 anos de reclusão), assim é indicada uma avaliação mais criteriosa dos aspectos pessoais do apenado no momento progressão para verificar se a pena imposta foi importante para sua ressocialização e para aferir se ele apresenta mérito para progredir. No caso do HC 79.497/RJ (relator Ministro Néri da Silveira, julgado em 10/10/1999) a $2^{\circ}$ Turma também observa que "a concessão do benefício não pode levar em conta o que ocorreu no passado, mas, apenas, se estão reunidos os requisitos necessários". Assim, não se pode negar a progressão por haver procedimento administrativo para apurar autoria de fatos passados quando o apenado que foi recomendado no exame criminológico e pela Comissão Técnica de Classificação, já cumpriu o lapso temporal, uma vez que há a possibilidade de regressão de regime caso haja condenação futura.

Não temos subsídios para podermos traçar um panorama do posicionamento do STF sobre a admissibilidade do exame criminológico para avaliação do mérito no período de início da vigência da Lei 10.792/2003, porque, antes do julgamento do HC 82959/SP (Pleno, relator Ministro Marco Aurélio, julgado em 23 de fevereiro de 2006) o STF entendia ser constitucional a proibição da progressão de regime para condenados por crimes hediondos prescrita pela redação original da Lei $8.072 / 1990^{19}$. Desse modo, nos julgados anteriores do STF, os Ministros simplesmente negavam os pedidos de progressão de condenados por crimes hediondos por falta de previsão legal sem chegar a analisar os requisitos objetivos ou

\footnotetext{
${ }^{18}$ No mesmo sentido: HC 94258/SP ( $1^{\circ}$ Turma, relator Ministro Carlos Brito, julgado em 04/11/2008)

${ }^{19}$ A redação original do $\S 1^{\circ}$ do art. $2^{\circ}$ da Lei $8072 / 1990$, indicava que a pena por crime hediondo seria cumprida integralmente em regime fechado. Este comando legal foi considerado constitucional nos seguintes julgados do STF: RE 187567; HC 69657/SP; HC 76479; HC 78124; HC 71031; HC 71206; HC 71182; HC 71653; HC 71994; HC 72567; HC 72363; HC 74566; HC 70616; HC 74697; HC 76217; HC 76949; HC 76608; HC 77076; HC 77132; HC 77828; HC 78166; HC 78247; HC 78417
} 
subjetivos. No Informativo $\mathrm{N}^{\circ} 417^{20}$ do STF podemos encontrar encontramos um relato sobre o resultado e consequências jurídicas desse julgado.

Superada então a questão da possibilidade de progressão de regime penal para os condenados por crimes hediondos, passamos a analisar como o STF vem tratando a análise dos requisitos subjetivos do apenado na progressão de seu regime prisional.

No HC 85688/PR (Relator Ministro Eros Grau, julgado em 03/05/2005), a $1^{\circ}$ Turma do STF entendeu que não mais é necessária a análise do mérito do condenado e determinou de ofício a progressão de regime uma vez que, no caso concreto em análise, demonstrou-se cumpridos os requisitos do artigo 112 da LEP (cumprimento de 1/6 da pena e bom comportamento carcerário).

A decisão proferida no julgamento do HC 88052/DF (2 ${ }^{\circ}$ Turma, relator Ministro Celso de Mello, julgado em 04/04/2006) é de fundamental importância para sedimentar a jurisprudência brasileira a respeito do assunto, pois influenciou não somente a jurisprudência do STF, mas também a veio por modificar a jurisprudência que se firmava em sentido contrario no STJ. O Ministro Celso de Mello, relator desse processo, observou em seu voto que o pleno do STF já havia advertido no julgamento do HC 82.959/SP que a proclamação de inconstitucionalidade á vedação à progressão de regime não incidirá sobre o exercício da competência do Juiz da primeira instancia em sede de execução penal, cabendo a este avaliar criteriosamente o preenchimento dos demais requisitos obrigatórios na progressão

\footnotetext{
20 “Em conclusão de julgamento, o Tribunal, por maioria, deferiu pedido de habeas corpus e declarou, incidenter tantum, a inconstitucionalidade do $\S 1^{\circ}$ do art. $2^{\circ}$ da Lei 8.072/90, que veda a possibilidade de progressão do regime de cumprimento da pena nos crimes hediondos definidos no art. $1^{\circ}$ do mesmo diploma legal - v. Informativos 315, 334 e 372. Inicialmente, o Tribunal resolveu restringir a análise da matéria à progressão de regime, tendo em conta o pedido formulado. Quanto a esse ponto, entendeu-se que a vedação de progressão de regime prevista na norma impugnada afronta o direito à individualização da pena (CFB, art. $\left.5^{\circ}, \mathrm{LXVI}\right)$, já que, ao não permitir que se considerem as particularidades de cada pessoa, a sua capacidade de reintegração social e os esforços aplicados com vistas à ressocialização, acaba tornando inócua a garantia constitucional. Ressaltou-se, também, que o dispositivo impugnado apresenta incoerência, porquanto impede a progressividade, mas admite o livramento condicional após o cumprimento de dois terços da pena (Lei 8.072/90, art. $5^{\circ}$ ). Considerou-se, ademais, ter havido derrogação tácita do $\S 1^{\circ}$ do art. $2^{\circ}$ da Lei $8.072 / 90$ pela Lei $9.455 / 97$, que dispõe sobre os crimes de tortura, haja vista ser norma mais benéfica, já que permite, pelo $\S 7^{\circ}$ do seu art. $1^{\circ}$, a progressividade do regime de cumprimento da pena. [...]. O Tribunal, por unanimidade, explicitou que a declaração incidental de inconstitucionalidade do preceito legal em questão não gerará consequências jurídicas com relação às penas já extintas nesta data, já que a decisão plenária envolve, unicamente, o afastamento do óbice representado pela norma ora declarada inconstitucional, sem prejuízo da apreciação, caso a caso, pelo magistrado competente, dos demais requisitos pertinentes ao reconhecimento da possibilidade de progressão". (STF, Informativo $\mathrm{N}^{\circ} 417,20$ de fevereiro a 3 de março de 2006)
} 
do sentenciado para regime penal menos gravoso. Essa orientação jurisprudencial é reforçada pelo posicionamento do Supremo de considerar inadequada a via sumaríssima do habeas corpus para exame dos critérios subjetivos obrigatórios na progressão para regime mais favorável. Em seu relatório, o Ministro também considerou que:

"Não constitui demasia assinalar, neste ponto, não obstante o advento da Lei
$\mathrm{N}^{\circ} 10.792 / 2003$, que alterou o art. 112 da LEP para dele excluir a referência
ao exame criminológico, que nada impede que os magistrados determinem a
realização de mencionado exame, quando o entenderem necessário,
consideradas as eventuais peculiaridades do caso, desde que o façam,
contudo, em decisão adequadamente motivada". (HC 88052/DF, $2^{\circ}$ Turma,
relator Ministro Celso de Melo, julgado em 04/04/2006)

Para o Relator, esse entendimento pode ser justificado porque o exame criminológico, embora não seja mais indispensável, é um parecer técnico importante na aferição da personalidade e do grau de periculosidade do sentenciado e possibilita que o magistrado tome uma decisão mais consciente a respeito do beneficio concedido ao condenado, sendo de utilidade inquestionável. Assim, ele entende que o magistrado de $1^{\circ}$ grau deve avaliar discricionariamente a necessidade de realização do referido exame diante das peculiaridades do caso concreto e, entendendo necessária a sua realização, pode então determiná-la através de decisão adequadamente motivada ${ }^{21}$.

No acórdão do HC 86631/PR (relator Ministro Ricardo Lewandowski , julgado em 05/09/2006), os Ministros da $1^{\circ}$ Turma também seguiram o posicionamento adotado pela $2^{\circ}$ Turma no julgamento do HC 88052/DF. No caso, os Ministros observam que, fazendo-se uma interpretação sistemática dos preceitos dos artigos $8^{\circ}$ e 112 da Lei de Execução Penal com o art. $33 \$ 2^{\circ}$ do Código Penal, é admitido ao Magistrado determinar a realização de exame criminológico para melhor aferir as características subjetivas do apenado, observadas às peculiaridades do caso concreto. $\mathrm{O}$ resultado desse julgamento foi publicado no Informativo $\mathrm{N}^{\circ} 439$ do $\mathrm{STF}^{22}$.

\footnotetext{
${ }^{21}$ Os acórdãos do HC 88005/SP (julgado em 04/04/2006) e do HC 95323/RS (julgado em 07/10/2008) também apresentam ementa idêntica à do HC 88.052/DF. No mesmo sentido destas decisões citamos ainda os seguintes julgados da $2^{\circ}$ Turma: HC 87884/SP (julgado em 14/03/2006); RHC 88145/GO (julgado em 14/03/2006); HC 87283/DF (julgado em 21/03/2006); e HC 88058/SP (julgado em 04/04/2006).

22 “A Turma, por maioria, indeferiu habeas corpus em que condenado a cumprimento de pena em regime fechado pleiteava a progressão de regime, sob a alegação de que, com a nova redação dada pela Lei 10.792/2003 ao art. 112 da Lei de Execução Penal, seria desnecessária a realização de exame criminológico [...]. Sustentavase, na espécie, o preenchimento dos requisitos objetivos, quais sejam, cumprimento de, pelo menos, um sexto da
} 
Neste informativo, o STF considera que a partir de interpretação sistemática do dos preceitos do art. 33, $\S 2^{\circ}$ do CPB e do art. $8^{\circ}$ da LEP pode-se concluir que a Lei 10.792/2003 não teve por objetivo extirpar o exame criminológico na avaliação dos pedidos de progressão do regime, apenas "introduziu critérios norteadores à decisão do juiz para dar concreção ao princípio da individualização da pena", uma vez que a realização do exame somente será indicada quando o juiz motivadamente determinar diante das particularidades do caso $^{23}$.

No HC 92891/SP (2 Turma, relator Ministro Joaquim Barbosa, julgado em 03/06/2008) o STF observou que a progressão dos regimes na execução progressiva da pena tem como "razão maior a ressocialização do preso que, mais dia ou menos dia, voltará ao convívio social". Também observam que a Lei $11.464 / 2007^{24}$ só é aplicada a crimes praticados após a sua vigência. Desse modo, o lapso temporal a ser cumprido será o de 1/6 da pena previsto no artigo 112 da LEP. No mesmo sentido, destacamos o HC 94258/SP (1 Turma, relator Carlos Britto, julgado em 04/11/2008), no qual os Ministros ainda ressaltaram que cabe ao magistrado de $1^{\circ}$ grau a aferição dos requisitos objetivo e subjetivos para progressão de regime prisional. No entanto, em ambos os casos não há referencias do STF a respeito dos requisitos subjetivos.

No HC 93108/SP (relatora Ministra Cármen Lúcia, julgado em 25/11/2008) a $1^{\circ}$ Turma observou que o Art. $5^{\circ}$, LXXVIII, da Constituição Federal garante ao paciente o direito à razoável duração dos processos administrativos e judiciais e assegurou liberdade condicional ao paciente que já havia cumprido mais de 3/4 (três quartos) da pena, pois o exame criminológico não seria concluído antes de seu cumprimento integral.

pena e a existência de bom comportamento carcerário, comprovado por declaração prestada pelo diretor do estabelecimento prisional.Entendeu-se que o aludido art. 112 da LEP, em sua nova redação, admite a realização facultativa do exame criminológico, desde que fundamentada e quando necessária à avaliação do condenado e de seu mérito para a promoção a regime mais brando. Ressaltou-se, ainda, que esse exame pode ser contestado, nos termos do $\S 1^{\circ}$ do próprio art. 112, o qual prevê a instauração de contraditório sumário. A partir de interpretação sistemática do ordenamento (CP, art. $33, \S 2^{\circ}$ e LEP, art. $\left.8^{\circ}\right)$, concluiu-se, que a citada alteração não objetivou a supressão do exame criminológico para fins de progressão do regime, mas, ao contrário, introduziu critérios norteadores à decisão do juiz para dar concreção ao princípio da individualização da pena." (STF, Informativo $\mathrm{N}^{\mathrm{o}} 439,4$ a 8 de setembro de 2006)

${ }^{23}$ No mesmo sentido, podemos citar as seguintes decisões da $1^{\circ}$ Turma: HC 94826/RS (relator Ministro Ricardo Lewandowski, julgado em 28/10/2008) e HC 94612/RS (relator Ministro Carlos Britto, julgado em 17/03/2009)

${ }^{24}$ A Lei 11.464/2007 alterou a redação original da Lei 8072/1990, que então passou a admitir a progressão de regime para condenados por crimes hediondos e equiparados após o cumprimento de $2 / 5$ (dois quintos) da pena para o apenado for primário, e de $3 / 5$ (três quintos) se o ele for reincidente. 
Nos julgados mais recentes, a $2^{\circ}$ Turma do STF vem mantendo seu posicionamento jurisprudencial no sentido de que o juiz pode determinar, através de decisão motivada, a realização do exame criminológico ${ }^{25}$. No acórdão HC 96586/SP (relator Ministro Celso de Mello, julgado em 24/03/2009), os Ministros ressaltam que a legitimidade para determinar a realização do exame criminológico é do o poder judiciário. Já no HC 96362/RS (relator Ministro Eros Grau, julgado em 24/03/2009), a Turma salienta que "a realização do exame criminológico não exime o Juiz de fundamentar a decisão que indefere o pedido de progressão de regime, ainda que o laudo pericial seja desfavorável ao paciente".

No HC 96660/RS (relator Ministro Ricardo Lewandowski, julgado em 23/06/2009), a $1^{\circ}$ Turma do STF indeferiu pedido de habeas corpus observando que a alegada falta de fundamentos da decisão que determinou a realização do exame criminológico deveria ter sido suscitada junto ao Superior Tribunal de Justiça, o que impede a avaliação do STF devido à supressão de instância e extrapolação de competência.

Em 16/12/2009, o Pleno do Supremo aprovou a edição da Súmula Vinculante de $\mathrm{N}^{\circ} 26^{26}$ que pacifica o entendimento jurisprudencial a respeito do assunto quando crime for hediondo ou equiparado. A referida Súmula possui o seguinte enunciado:

"Para efeito de progressão de regime no cumprimento de pena por crime
hediondo, ou equiparado, o juízo da execução observará a
inconstitucionalidade do art. $2^{\circ}$ da Lei n. 8.072 , de 25 de julho de 1990 , sem
prejuízo de avaliar se o condenado preenche, ou não, os requisitos objetivos
e subjetivos do benefício, podendo determinar, para tal fim, de modo
fundamentado, a realização de exame criminológico" (STF, Pleno,
23/12/2009)

Nos julgados de 2010, a $1^{\circ}$ Turma do STF vem seguindo a orientação de admitir a realização do exame criminológico, em decisão motiva e de acordo com as peculiaridades do caso concreto, mesmo para crimes não hediondos. Nos acórdãos os acórdãos referentes ao HC 97453/RS ( $1^{\circ}$ Turma, Cármen Lúcia, julgado em 23/03/2010) e HC

\footnotetext{
25 Destacamos como exemplos os seguintes acórdãos: HC 96362/RS (relator Ministro Eros Grau, julgado em 24/03/2009); HC 96586/SP (relator Ministro Celso de Mello, julgado em 24/03/2009); HC 101050/RS (relatora Ministra Ellen Gracie, julgado em 24/11/2009); HC 99638/SP (relator Ministro Eros Grau, julgado em 10/11/2009).

${ }^{26}$ Após a edição da Súmula Vinculante 26, destacamos os seguintes acórdãos do STF: HC 102666/RS ( $1^{\circ}$ turma, relatora Ministra Cármen Lúcia, julgado em 13/04/2010); HC 98243/RS ( $2^{\circ}$ turma, relator Ministro Gilmar Mendes, julgado em 10/08/2010); HC 104014/SP ( $2^{\circ}$ turma, relator Ministro Gilmar Mendes, julgado em 14/09/2010); HC 101116/SP ( $2^{\circ}$ turma, relator Ministro Gilmar Mendes, julgado em 26/10/2010)
} 
103733/SP (relator Ministro Ricardo Lewandowski, julgado em 26/10/2010) indicam que o pedido foi justificado pela fuga anterior dos apenados do estabelecimento semiaberto. Nos acórdãos do HC 101270/SP (relator Ministro Dias Toffoli, julgado em 13/04/2010) e do HC 101264/RS (relator Ministro Dias Toffoli, julgado em 07/04/2010) a realização do o exame foi motivada pela prática de faltas disciplinares de natureza grave, e no último caso a reincidência na prática de novos delitos também indicou para a necessidade de avaliar o mérito do condenado. Ainda observamos nesses recentes julgados que o Ministro Marco Aurélio continua não admitindo a realização do exame criminológico diante da atual redação do artigo 112 da Lei de Execução Penal.

\subsubsection{Jurisprudência do STJ}

Começamos essa seção apresentando duas importantes decisões tomadas pelo STJ antes da vigência da Lei 10.792/2003. No RHC 3951/RS (5 Turma, relator Ministro Edson Vidigal, julgado 17/10/1994) o STJ admitiu a realização de exame criminológico para condenado por fato anterior à vigência da LEP e o acórdão do HC 2832/RJ, (6 ${ }^{\circ}$ Turma, relator Ministro Anselmo Santiago, julgado em 11/11/1994) demonstra que o juiz não é vinculado ao resultado exame, pois nesse caso ele requisitou também o parecer da Comissão Técnica de Classificação para auxiliar na formação de sua convicção pessoal, nos termos dos artigos 156 e 157 do CPC.

Nas decisões do proferidas após o inicio da vigência da Lei 10.792/2003, os ministros do Superior Tribunal de Justiça entenderam que, "embora temerário substituir a exigência de parecer da Comissão Técnica de Classificação e a submissão do presidiário a exame criminológico" (HC 38602/PR, 5 Turma, relator Ministro Arnaldo Esteves Lima, julgado em 09/11/2004), a intenção do legislador ao modificar a redação do artigo 112 da LEP, foi realizar a aferição do mérito do condenado através do atestado de boa conduta carcerária, único requisito subjetivo para a progressão ${ }^{27}$.

Entretanto, no mesmo período há decisões da $5^{\circ}$ Turma que consideraram admissível a realização do exame criminológico, observadas as peculiaridades da causa e em

\footnotetext{
${ }^{27}$ No mesmo sentido, destacamos os acórdãos: HC 45431/SP (5º Turma, relator Ministro Arnaldo Esteves Lima, julgado em 06/12/2005); HC 40299/RS (6º Turma, relator Ministro Hélio Quaglia Barbosa, julgado em 02/08/2005) e HC 42677/RS (6º Turma, relator Ministro Hélio Quaglia Barbosa, julgado em 02/08/2005).
} 
decisão fundamentada (HC 37440/RS, relator Ministro Gilson Dipp, julgado em 02/12/2004) e em razão de respeito ao princípio da individualização da pena do art. $5^{\circ}$, inciso XLVI, CFB 1988 (HC 42513/PR, relatora Ministra Laurita Vaz, julgado em 28/06/2005). Todavia, o STJ não admitiu fundamentação da decisão feita com base em argumentos genéricos como "in dubio pro societate" (HC 46099/SP, relatora Ministra Laurita Vaz, julgado em 21/02/2006).

No REsp 623032/RS (relator Ministro Paulo Medina, julgado em 31/05/2005), a $6^{\circ}$ Turma considerou que a "má conduta" impede a progressão, pois implica em não cumprimento do requisito subjetivo do artigo 112 da Lei de Execução Penal.

Em de abril de 2006, a $5^{\circ}$ Turma do STJ chegou a firmar entendimento no sentido não admitir o exame criminológico nos pedidos de progressão, bastando o cumprimento do requisito temporal e bom comportamento carcerário, conforme art. 112 da LEP. Nesse sentido destacamos o HC 52230/SP (relator Ministro Gilson Dipp, julgado em 25/04/2006), o Agravo Regimental no HC 51249/DF (relator Ministro Hélio Quaglia Barbosa julgado em 25/04/2006) e o REsp 828324/RS (relator Ministro Gilson Dipp, julgado em 12/06/2006).

No entanto, a partir de agosto de 2006, a $5^{\circ}$ Turma passou a seguir o precedente do HC 88.052/DF do STF (julgado em 03/08/2006), voltando a admitir a realização facultativa do exame criminológico se as peculiaridades do caso concreto assim indicarem.

A $5^{\circ}$ Turma admite a progressão concedida com base apenas no atestado de boa conduta carcerária, salientando que a dispensa do exame criminológico não precisa de motivação $^{28}$. No entanto, a Turma salienta no HC 124.691/SP (relator Ministro Napoleão Maia Filho, julgado em 26/05/2009) que o cumprimento do lapso temporal e o atestado de bom comportamento não implicam em direito subjetivo do condenado, pois o Juiz pode

\footnotetext{
${ }^{28}$ Nesse sentido observamos os seguintes acórdãos: REsp 849.150/RS (relator Ministro Gilson Dipp, julgado em 12/09/2006); REsp 810.234/RS (relatora Ministra Laurita Vaz, julgado em 10/10/2006); HC 61.203/SP (relator Ministro Arnaldo Esteves Lima, julgado em 14/11/2006); do REsp 841662/RS (relator Ministro Felix Fischer, julgado em 12/12/2006); HC 60.181/SP (relator Ministro Gilson Dipp, julgado em 12/12/2006); HC 68.606/RJ (relator Ministro Gilson Dipp, julgado em 12/12/2006); HC 67441/PR, (relator Ministro Felix Fischer, julgado em 13/02/2007); e HC 69560/GO (relator Ministro Arnaldo Esteves de Lima, julgado em 27/02/2007).
} 
solicitar outros elementos de convencimento pessoal e fundamentadamente negar a progressão de regime.

O STJ considera que o resultado do exame criminológico por si só não vincula o Tribunal, que pode reformar a decisão de $1^{\circ}$ grau e conceder a progressão observando o atestado de bom comportamento carcerário. No entanto, a $5^{\circ}$ turma observa que o acórdão que reformar tais decisões deve ser suficientemente fundamentado ${ }^{29}$.

Com base nos diversos acórdãos analisados, observamos que o STJ considera a fundamentação idônea um requisito fundamental da decisão que porventura venha a negar progressão com base no resultado do exame criminológico. Nessas decisões, encontramos diversos motivos que foram aceitos para fundamentar a realização do exame.

No HC 65886/MG (relator Ministro Gilson Dipp, julgado em 06/02/2007), a $5^{\circ}$ Turma considerou como fundamento suficiente as particularidades do paciente condenado por homicídio qualificado, lesão corporal e extorsão. A mesma Turma admitiu como fundamentação idônea a autoria de crimes hediondos (atentado violento ao pudor e homicídio tentado) no acórdão do HC 121.818/RS (relatora Ministra Laurita Vaz, julgado em 13/08/2009). Já no HC 134.622/SP (relatora Ministra Laurita Vaz, julgado em 20/08/2009) a $5^{\circ}$ Turma aceitou o exame criminológico justificado com base na periculosidade do agente (condenado por crime hediondo) e na prática de falta média.

A $6^{\circ}$ Turma do STJ considerou que o relator pode fundamentar o acórdão com base em parecer do Ministério Público que analisa toda a tese defensiva motivadamente (HC 93345/RS, relator Ministro Og Fernandes, julgado em 06/08/2009) e também admitiu como valida a justificação para realização do exame motivada pela reincidência na pratica criminosa (HC 120.935/SP, Rel. Ministro Celso Limongi, julgado em 18/02/2010). No acórdão do HC 120.935/SP, os Ministros ainda observam que o despacho ordenatório de realização do exame criminológico não precisa de fundamentação, apenas a decisão final sobre a progressão é que necessita da fundamentação idônea.

\footnotetext{
${ }^{29}$ Nesse sentido, destacamos os seguintes acórdãos: HC 66567/SP (relator Ministro Gilson Dipp, julgado em 06/02/2007); HC 65671/SP (relator Ministro Gilson Dipp, julgado em 15/02/2007; e REsp 1156072/RS (relator Ministro Arnaldo Esteves de Lima, julgado em 02/03/2010).
} 
O cometimento de falta grave no curso da execução também tem sido utilizado como fundamento aceito pelo STJ para justificar a realização do exame criminológico. Nesses casos, a $5^{\circ}$ turma do STJ já se pronunciou no sentido de que a prática de falta grave incide sobre o requisito objetivo da progressão, pois interrompe o lapso temporal e implica no reinício da contagem do prazo para progressão de regime, que será calculado sobre o remanescente da pena a ser cumprida. Nesse sentido temos os acórdãos do HC 64909/PR (relator Ministro Gilson Dipp, julgado em 12/12/2006), do HC 124.447/SP (relator Ministro Napoleão Maia Filho, julgado em 26/05/2009). Já no acórdão do HC 40895/SP (relator Arnaldo Esteves de Lima, julgado em 16/06/2005), a $5^{\circ}$ Turma entendeu que, havendo falta grave pendente de julgamento administrativo, o direito subjetivo à progressão fica condicionado a comprovação de sua não ocorrência.

Nos julgados mais recentes, observa-se que é recorrente o exame motivado pelo cometimento de falta grave no curso da execução, pela periculosidade concreta do agente ou pela conjugação desses fatores. No HC 124.992/SP (5 $5^{\circ}$ Turma, relator Ministro Arnaldo Esteves Lima, julgado em 04/06/2009), o exame foi realizado devido a condenação por latrocínio e pratica de falta grave na execução. No HC 143.629/SP ( $6^{\circ}$ Turma, relator Ministro Og Fernandes, julgado em 02/02/2010), falta grave, fuga e prisão em flagrante por novo crime. O acórdão do HC 153.180/RS (6 Turma, relator Ministro Og Fernandes, julgado em 04/03/2010) indica como justificativas o histórico de fugas e pratica de várias faltas graves. O HC 147.360/SP (5 Turma, relatora Ministra Laurita Vaz, julgado em 09/03/2010), por seu turno, aponta como motivos ocorrência de faltas graves e condenação por crime hediondo. No acórdão do HC 153.138/SP (5 Turma, relator Ministro Felix Fischer, julgado em 16/03/2010), a reiterada atividade delitiva (extorsão mediante sequestro, roubo e homicídio) é o fundamento do exame. No HC 154.278/SP ( $5^{\circ}$ Turma, relator Ministro Felix Fischer, julgado em 23/03/2010) encontramos como razoes para o exame o cometimento de faltas graves (desacato, posse de entorpecentes, ameaça a funcionário e danos) e a reiterada pratica delitiva (homicídio tentado, danos, furtos simples e qualificado).

Depois de diversas decisões admitindo a realização do exame criminológico e após a edição da Súmula Vinculante $N^{\circ} 26$ do STF, a Terceira Seção do Superior Tribunal de Justiça (que inclui a $5^{\circ}$ e a $6^{\circ}$ Turmas) resolveu sedimentar seu entendimento sobre o assunto editando, em 28 de abril de 2010, a Súmula 439, com o seguinte enunciado: “Admitese o exame criminológico pelas peculiaridades do caso, desde que em decisão motivada". 
Os julgados realizados após a edição da Súmula 439 fazem referencia expressa a ela e apresentam fundamentos para realização do exame criminológico semelhantes aos apresentados nos julgados anteriores.

Há julgados onde o exame é justificado pelas peculiaridades da personalidade do agente. No HC 159.644/SP ( $5^{\circ}$ Turma, relatora Ministra Laurita Vaz, julgado em 18/05/2010) recomendam exame do condenado reincidente (por pratica de furto, roubo, latrocínio e posse de entorpecentes) com longa pena a cumprir. O acórdão do HC 142.309/SP ( $5^{\circ}$ Turma, relator Ministro Jorge Mussi, julgado em 01/06/2010) indica que a periculosidade do condenado é evidenciada pela gravidade em concreto dos crimes praticados e pela reiterada pratica de graves crimes patrimoniais. Já o HC 136.358/SP (5 Turma, relatora Ministra Laurita Vaz, julgado em 14/09/2010) justifica o exame pelo reiterado envolvido em delitos de maior gravidade (bando armado, roubo triplamente circunstanciado, sequestro e cárcere privado) e pela longa condenação a cumprir.

Em outros casos, o exame foi realizado para apenados que se aproveitaram das menores restrições impostas, enquanto estavam cumprindo pena em regime semiaberto ou aberto, para praticar novos crimes. No caso do HC 169.968/SP (6 $6^{\circ}$ Turma, relator Ministro Celso Limongi, julgado em 19/08/2010) o condenado cometeu novo de roubo quando estava em regime semiaberto. No HC 160.867/RS (5 Turma, relatora Ministra Laurita Vaz, julgado em 02/09/2010) a periculosidade é evidenciada pela condenação por roubo e estupro e pela prática de falta grave e de novos delitos quando progredido ao regime intermediário. $\mathrm{O}$ acórdão do HC 157.115/SP (6 $6^{\circ}$ Turma, relator Ministro Celso Limongi, julgado em 31/08/2010) aponta como razões do exame a fuga do estabelecimento semiaberto e pratica de novo crime durante o período de evasão. Já no caso do HC 156.383/SP ( $6^{\circ}$ Turma, relatora Ministra Maria Thereza de Assis Moura, julgado em 18/05/2010) o condenado foi preso em flagrante por novo delito enquanto estava em liberdade condicional.

No entanto, há outros casos em que a decisão que denega a progressão em função do exame criminológico não apresentou motivação idônea ou não indicou as particularidades do caso que justificam a realização do mesmo. Nesses casos o STJ reformou o acórdão e concedeu a ordem para garantir a progressão ao condenado com base nos requisitos do artigo 112 da LEP, não aceitando como fundamentação argumentos como "a 
gravidade abstrata do delito", "a longa pena a cumprir" ou "o histórico de faltas disciplinares".

No acórdão do HC 128.983/SP (5 Turma, relator Ministro Felix Fisher julgado em 23/06/2009) o STJ considerou constrangimento ilegal o indeferimento da progressão baseado em fundamentos extralegais, como histórico de faltas disciplinares, ainda mais quando já se cumpriu novo lapso temporal após sua prática. No caso do HC 149.299/SP (5 $5^{\circ}$ Turma, relator Ministro Arnaldo Esteves Lima, julgado em 23/03/2010), falta grave cometida há mais de 10 anos não pode servir de fundamentação idônea para a realização de exame criminológico, no caso observam que "as sanções já foram cumpridas e a contagem dos prazos foi refeita, encontrando-se o requisito objetivo cumprido".

No HC 128.848/ES ( $6^{\circ}$ Turma, relator Ministro Celso Limongi, julgado em 04/03/2010) os Ministros consideram que o histórico de fugas e a condenação por crime hediondo não eximem o tribunal de origem de fundamentar sua decisão. Na decisão do HC 145.111/SP (5 Turma, relatora Ministra Laurita Vaz, julgado em 21/09/2010) observam que o Tribunal não apresentou fundamentação idônea ao reformar a decisão de $1^{\circ}$ instância. No REsp 1124112/RS (5 Turma, relator Ministro Felix Fischer, julgado em 23/03/2010) o STJ desconsiderou o resultado desfavorável do laudo que apresentava conclusões vagas e a falta de motivação idônea do Tribunal de origem para cassar o acórdão recorrido.

Já no HC 151.268/PR (6 $6^{\circ}$ Turma, relator Ministro Og Fernandes, julgado em 20/04/2010), salientaram que "a gravidade abstrata do delito praticado e a longevidade da pena a cumprir, por si sós, não constituem fundamentação idônea a exigir a realização de exame criminológico". No caso, ainda observam a proibição da progressão por salto, indicando a necessidade de se respeitar os períodos de tempo a serem cumpridos em cada regime prisional. Já no HC 165.330/RS (5 Turma, relatora Ministra Laurita Vaz, julgado em 22/06/2010) o STJ considerou que a gravidade genérica do delito e o fato do condenado não exercer atividade externa no regime semiaberto não servem fundamentos para realização do exame criminológico e impedir a progressão para o regime aberto.

Após analise dos diversos acórdãos apresentados podemos destacar também outros aspectos relevantes observados na jurisprudência do Superior Tribunal de Justiça. 
Em primeiro lugar, observamos que o STJ não admite a analise de requisitos de ordem subjetiva em via de habeas corpus, por entender que implicaria em adentrar na seara fático-probatória. Nesse sentido: HC 39364/PR (5 Turma, relatora Ministra Laurita Vaz, julgado em 03/02/2005) e HC 124691/SP (5 Turma, relator Ministro Napoleão Maia Filho, julgado em 26/05/2009). No REsp 1187448/RS (5 Turma, relator Ministro Felix Fischer, julgado em 02/09/2010) os Ministros não conheceram o recurso por salientar que somente poderia se pronunciar a partir do reexame de fatos e provas não contidos no acórdão reprochado, procedimento este incompatível com a Súmula 07 do STJ.

O STJ também não admite avaliar o pleito ainda não julgado pela instância ordinária devido à proibição de supressão de instância. Nesse sentido: HC 63195/RS (5 Turma, relatora Ministra Laurita Vaz, julgado 10/10/2006) e HC 71488/GO (5 Turma, relatora Ministra Laurita Vaz, julgado em 15/02/2007).

Salientamos que há entendimento pacifico no STJ de que o lapso temporal prescrito pela Lei 8072/90 para os condenados por crimes hediondos é evidentemente mais gravoso ao apenado e não se aplica a fatos praticados antes da vigência da Lei 11.464/2007. Dessa forma, o lapso exigido para a progressão será de o de 1/6 da pena, conforme prevê o art. 112 da $\operatorname{LEP}^{30}$.

Por fim, observamos que o STJ considera o exame criminológico um "procedimento que não constrange quem a ele se submete, pois se trata de avaliação nãoinvasiva da pessoa, já que se efetiva por meio de entrevista com técnico ou especialista, não produzindo qualquer ofensa física ou moral”. (HC 177.580/SP, $5^{\circ}$ Turma, relator Ministro Napoleão Maia Filho, julgado em 21/10/2010).

30 Nesse sentido citamos os seguintes acórdãos: HC 134.622/SP; HC 147.359/SP; HC 120.935/SP; HC 147.905/SP; HC 147.360/SP; HC 153.138/SP; HC 154.278/SP; e HC 151.268/PR 


\section{CRÍTICA A RESPEITO DAS MUDANÇAS INTRODUZIDAS PELA LEI 10.792/2003 E PROPOSTAS DE NOVAS ALTERAÇÕES LEGISLATIVAS}

\subsection{Criticas sobre o posicionamento doutrinário}

A edição da Lei 10.792/2003 novamente reflete a forma com que o poder público brasileiro tem agido nos últimos anos diante do problema do crescente aumento nos índices de violência: procura encurtar o caminho utilizando o Direito Penal como resposta imediata ao anseio da sociedade de submeter os criminosos mais perigosos (lideres de organizações como o PCC) a regras mais rígidas na execução de sua pena. O poder público ainda aproveitou este mesmo o momento de mudanças para tentar amenizar outro problema decorrente da má administração dos recursos públicos: a falta de vagas nos presídios.

Para nós, as mudanças como essas não atacaram o problema em sua base e significaram apenas uma solução paliativa para os problemas de combate à criminalidade e de redução da superlotação carcerária. Novamente tenta-se maquiar os problemas da execução penal através da adoção de medidas pontuais que não consideram o sistema como um todo, e mais uma vez a solução adotada não se mostra adequada, pois não se ataca o principal o problema que é a falta de estrutura do sistema penitenciário brasileiro.

Podemos dizer que desde a edição da Lei 10.792/2003 não se observou melhoras significativas no sistema. O que se viu na prática da execução penal é que a alteração legislativa na Lei de Execução Penal conseguiu dar fluência aos pedidos de progressão de regime e de livramento condicional de condenados que antes ficavam aguardando a inércia da máquina estatal para a realização do exame criminológico.

Quanto às mudanças nos critérios de progressão, não concordamos com o posicionamento doutrinário de Luiz Flávio Gomes, Patrícia Donati Almeida e Elisa Maria Rudge Ramos (2009) de que o condenado não precisa demonstrar arrependimento ou mudança no caráter e personalidade e busca de adaptação ao novo regime durante a execução da pena, e que basta possuir bom comportamento e cumprir o lapso temporal para progredir. 
Em nossa avaliação, essa visão não é compatível com a concepção, limites e finalidades da pena propostos pela reforma de 1984 , pois sugere a ideia de que, a partir de $1^{\circ}$ de dezembro de 2003, a pena no Brasil não mais precisa estar em harmonia com os postulados da defesa social. Assim a pena voltaria a apresentar a concepção retributiva clássica (cf. FRAGOSO, 1980, p. 5), já que o condenado não precisaria demonstrar (e nos somos proibidos de avaliar) o aspecto pessoal relativo à sua recuperação e capacidade de adaptação ao novo regime penitenciário no momento de diminuir as restrições impostas a ele ou ao autorizar o seu retorno ao convívio social em liberdade.

Para alguns autores (cf. Elisa Maria Rudge Ramos, Luiz Flávio Gomes \& Patrícia Donati Almeida, 2009; Bruna Fernandes Pinatto \& Marcus Vinícius Feltrim Aquotti, 2009) a análise dos requisitos subjetivos para a progressão foi abolida da Lei de Execução Penal, não se fazendo mais necessária avaliação do mérito pelo exame criminológico.

Para nós, esse tipo de concepção apresenta alguns problemas. O primeiro é que considerar a avaliação de comportamento um critério objetivo não está correto. O bom comportamento é atestado com base em valoração subjetiva do Diretor do estabelecimento, pois a LEP não define os critérios a serem seguidos.

Outro problema é que o bom comportamento apresentado no interior do presídio só mostra a submissão às regras impostas durante o período em que o condenado está submetido a um rígido controle e supervisão dos agentes estatais. Sérgio Pitombo (1999) afirmou que não podemos avaliar o grau de recuperação do condenado exclusivamente com base na disciplina exteriorizada no ambiente carcerário, pois ela não tem relação com direta com a periculosidade do apenado. Por fim, lembramos que a avaliação do comportamento se inicia com a execução da pena, uma vez que a reprovabilidade da conduta do agente já foi aferida pelo Juiz na sentença condenatória.

O último problema gerado pela Lei 10.792/2003 é que o juiz da execução penal passa a ser um mero homologador de certidões, pois sua decisão limita-se a verificar o decurso do lapso temporal e o atestado de bom comportamento. Acaba que real decisão da progressão foi transferida para a esfera administrativa que atestará o bom comportamento. Podemos considerar esse modelo como uma afronta ao principio da jurisdicionalização do Direito de Execução Penal, previsto no artigo 194 da LEP. 
Se considerarmos que a avaliação do aspecto subjetivo do condenado hoje se resume a verificar se o interno teve atestado o bom comportamento pelo diretor do estabelecimento prisional e que o juiz não tem liberdade para poder melhor analisar as condições subjetivas do apenado, recorrendo quando necessário ao auxilio do exame criminológico elaborado por técnicos especializados, estamos em rota de colisão com diversos outros preceitos legais ainda em vigor, dentre os quais destacamos o artigo 33 do Código Penal, os artigos 156 e 157 do Código de Processo Penal e ainda é uma afronta ao principio da individualização da pena previsto no art. $5^{\circ}$ da CFB.

Feitas essas considerações, passamos então a analisar como as mais altas cortes brasileiras tem se posicionado acerca da divergência doutrinária sobre a admissibilidade do exame criminológico para avaliação do mérito do condenado nos pedidos de progressão diante da modificação nos requisitos prescritos no artigo 112 da Lei de Execução Penal.

\subsection{Análise da jurisprudência do STF e do STJ}

Nas decisões tomadas antes da vigência da Lei 10.972/2003, o STF observou que o exame criminológico é um subsídio técnico ao magistrado, mas não pode substituir sua deliberação. STJ, por seu turno, salientou que o resultado do exame criminológico não vincula o juiz, que pode decidir motivadamente como base em outros elementos de convicção pessoal, conforme artigos 156 e 157 do CPP.

Nos julgados realizados antes da alteração na LEP, os Ministros do Supremo salientaram que o exame criminológico deve ser atual ao pedido de progressão, não deve considerar fatos passados do apenado, apenas deve avaliar se ele apresenta mérito para progredir. Consideram inadmissível avaliar os requisitos subjetivos em sede de habeas corpus e ainda anotam que eventual procedimento administrativo em curso não obsta a progressão de regime, pois há previsão da penalidade de regressão de regime na LEP.

Em julgados realizados após edição da Lei 10.972/2003, o STJ também não admite a analise de requisitos subjetivos em via de habeas corpus, pois implicaria em adentrar na seara fático-probatória inadmissível na via sumaríssima. 
No HC 85688/PR (julgado em 03/05/2005) a $1^{\circ}$ turma do STF sinalizou no sentido de não admitir exame criminológico nos pedidos de progressão, entendendo que o atestado de bom comportamento seria suficiente para atender ao requisito subjetivo. Esse posicionamento também foi adotado pelo STJ entendeu que, de acordo com nova redação do artigo 112 da LEP, o atestado de boa conduta carcerária era o único requisito subjetivo obrigatório para a progressão. Em abril de 2006, a $5^{\circ}$ Turma do STJ chegou a firmar entendimento no sentido não admitir o exame criminológico nos pedidos de progressão de Regime.

No entanto, em abril de 2006 (HC 88052/DF), a $2^{\circ}$ Turma do STF passa novamente a admitir o exame criminológico nos pedidos de progressão, justificando seu posicionamento em razão do exame ser um parecer técnico que possibilita avaliar a personalidade e o grau de periculosidade do sentenciado. Já em setembro de 2006, a $1^{\circ}$ Turma do STF também passa a decidir no mesmo sentido, justificando seu entendimento com base na interpretação sistemática dos artigos $8^{\circ}$ e 112 da Lei de Execução Penal com o artigo 33 $\S 2^{\circ}$ do Código Penal (STF, informativo 439). Essa orientação jurisprudencial também modificou o posicionamento do STJ, que também voltou a admitir a realização facultativa do exame criminológico.

A partir da analise das decisões mais recentes do STF e do STJ a respeito do assunto em tela, podemos notar que, atualmente, as mais altas cortes da justiça brasileira admitem a realização do exame criminológico para aferição do mérito, mediante decisões fundamentadas e observadas as peculiaridades dos casos concretos. Entendimento solidificado no STF em dezembro de 2009 com a edição da Súmula Vinculante $N^{\circ} 26$ e também no STJ através do enunciado da Súmula 439 de abril de 2010. Apesar da Súmula 26 referir-se apenas a crimes hediondos, observamos que o STF segue o mesmo entendimento para os demais tipos penais de maior gravidade.

Depois da analise dos acórdãos julgados após a alteração na Lei de Execução Penal, ainda podemos destacar diversos outros pontos em comum entre o entendimento jurisprudencial do STF e do STJ. 
Destacamos que o STJ considera que o juiz pode conceder a progressão observando apenas o atestado de bom comportamento carcerário nos termos do art. 112 da LEP e também observa que a dispensa do exame criminológico não necessita de motivação.

O Supremo salienta que a aferição dos requisitos objetivos e subjetivos para progressão deve ser feita pelo magistrado de $1^{\circ}$ grau e que somente o judiciário possui legitimidade para determinar a realização do exame criminológico.

O STF também considera que a decisão de negar a progressão diante de laudo desfavorável do exame criminológico deve ser suficientemente fundamentada. O STJ ainda adverte que a decisão que nega a progressão em consonância com resultado do exame deve apresentar fundamentação idônea que a justifique, mas observa que despacho ordenatório para a realização do exame não precisa de maior fundamentação.

Pudemos observar que diversos motivos que foram aceitos pelo STJ como fundamentação idônea da decisão proferida após a realização do exame criminológico, dentre os quais destacamos: o parecer do MP que analisa toda a tese defensiva motivadamente; a periculosidade do autor de crimes hediondos; a pratica de delitos de maior gravidade; a reincidência na pratica criminosa e ela conjugada com a longa pena a cumprir; a prática de novos crimes no regime semiaberto ou aberto; e o cometimento de falta grave no curso da execução. O STF também considerou motivos suficientes para admitir a realização do exame a prática de faltas disciplinares de natureza grave, a fuga e a reincidência na prática criminosa.

O STJ considerou que a prática de falta grave interrompe o lapso temporal e também observou que o direito subjetivo à progressão fica condicionado a comprovação da não ocorrência da falta pendente de julgamento administrativo. Salientamos que a Lei de Execução Penal ainda prevê que a falta grave pode acarretar regressão de regime para os condenados que cumprem pena em regime aberto ou semiaberto (art. 118) ou implicar no reinício da contagem do prazo para a progressão para os que estão em regime fechado (art. 127).

Os ministros do STJ reformaram alguns acórdãos que negaram a progressão de regime, mas não apresentavam motivação idônea para isso ou não indicavam as particularidades do caso que justificaram a realização do exame criminológico. O STJ não 
admite fundamentação baseada em argumentos genéricos como in dubio pro societate, a gravidade abstrata do delito, a longa pena a cumprir ou o histórico de faltas disciplinares.

No entanto, o STF não admite avaliar alegada falta de fundamentação não suscitada nas instancias inferiores razão de supressão de instância judicial. Pelas mesmas razões O STJ também não avalia os pedidos ainda não julgados na instância ordinária.

\subsection{Projetos de alterações legislativas}

O PLS 075/2007, apresentado pelo Senador Gerson Camata, propunha alterações na LEP de modo que a CTC voltaria a ter a função de propor à autoridade competente as progressões e regressões dos regimes para o caso de condenação por crime praticado com violência ou grave ameaça à pessoa. Também propõe o acréscimo de um $\S 3^{\circ}$ ao art. 112 da LEP, indicando a obrigatoriedade do parecer da Comissão Técnica de Classificação e do exame criminológico para estes condenados na progressão de regime, livramento condicional, indulto e comutação de pena. O projeto aponta que "a mera comprovação do bom comportamento carcerário [...] não alcança a avaliação por técnico das áreas psiquiátrica, psicológica e social e também considera que a não consideração do parecer da CTC constitui "flagrante desatenção aos interesses da segurança social" e que "o instituto da individualização da pena [...] foi dissipado de vez" após a edição da Lei 10.792/2003.

Pelo PLS 190/2007, proposto pela Senadora Maria do Carmo Alves, o art. 6 e caput do art. 112 da Lei de Execução Penal voltariam a ter a mesma redação original prescrita pela reforma de 1984. O art. 112 também voltaria a ter apenas um parágrafo, que indicaria a obrigatoriedade do parecer da Comissão Técnica de Classificação e do Ministério Público e, ainda, do exame criminológico, para condenados por crime de mais lesivos (hediondo, ou cometido mediante violência ou grave ameaça) e no caso de reincidência. A Senadora considera que "a comprovação do bom comportamento carcerário [...] não alcança a avaliação por técnico das áreas psiquiátrica, psicológica e social".

Em agosto de 2007, o Deputado Vieira da Cunha (PDT/RS) também apresentou na Câmara Federal duas propostas de alterações na Lei de Execução Penal e na Lei 8.072/1990 prevendo a obrigatoriedade de realização de exame criminológico para progressão 
de regime e livramento condicional aos condenados por crime doloso, cometido com violência ou grave ameaça à pessoa (PL 1764/2007) ou por crime hediondo ou equiparado (PL 1765/2007) que estiverem em regime fechado, e estabelece prazo de para realização do exame. O Deputado justifica adoção das medidas em razão da supremacia do "direito social coletivo de viver em segurança" frente ao "direito individual do preso à progressão do regime de cumprimento da pena", não tolerando que "a sociedade fique à mercê do retorno ao convívio social de um indivíduo que certamente voltará a delinquir” e observa que a natureza do crime hediondo recomenda que o "critério matemático" não deva ser o único a ser considerado na progressão. Diante da precária estrutura estatal para realização do exame propõe que convênios com Universidades para suprir tal deficiência. Observamos que a segunda proposta seria irrelevante diante da aprovação da primeira, uma vez que a Lei 8.072/1990 já obriga que o cumprimento de pena se inicie no regime fechado.

O Deputado Federal Marcelo Itagiba (PSDB-RJ) também apresentou duas propostas para a volta do Exame Criminológico durante a última legislatura. No PL 6285/2009 ele propõe que o exame também seja obrigatório no inicio do cumprimento da pena para o condenado em regime semiaberto e que todo condenado seja submetido ao exame antes da progressão ou do livramento condicional. Já no PL 6858/2010 propõe a criação de "Comissão Técnica Independente" composta de profissionais da área de saúde mental e de psicologia criminal que seria responsável por realizar um exame criminológico complementar para condenados em regime fechado, com finalidade de identificar os presos portadores de psicopatia e propor medidas adequadas à individualização da execução para tais condenados.

Por fim, destacamos o Projeto de Lei 6598/2009 do Deputado Federal Otavio Leite (PSDB/RJ) que propõe a obrigatoriedade de realização do exame criminológico para a concessão do livramento condicional e da progressão de regime aos condenados por crimes dolosos de forma geral. Indica no projeto a necessidade de observar a execução cientifica da pena e cita como justificativa o item 32 da exposição de motivos da Lei de Execução Penal de 1984.

Uma interessante solução alternativa é a apresentada pelo professor Alvino Augusto de Sá (2010, p. 211-215). Ele propõe que, na expedição do atestado de boa conduta seja realizada uma "avaliação técnica interdisciplinar da conduta". Para ele: 
"A melhor alternativa, para se tomarem decisões mais seguras sobre concessão de benefícios, não seria a avaliação isolada da conduta, mas sim uma avaliação técnica interdisciplinar da resposta do preso à terapêutica penal, a qual não mais se voltaria para os aspectos assim ditos criminológicos de sua personalidade e de seu passado, mas procuraria focalizar seu crescimento pessoal ao longo da execução penal, seu real compromisso com os valores ético-morais, os valores do trabalho, da justiça, da família, entre outros. Em todo esse conjunto de dados, estaria incluída a conduta, agora porém avaliada inclusive (mas não só) sobre o crivo técnico. A "boa ou ótima" conduta teria um significado mais complexo, tecnicamente interpretado e contextualizado. esta avaliação interdisciplinar seria feita pela CTC, integrada também por profissionais de segurança, constituindo-se aliás, no verdadeiro parecer da CTC, previsto na LEP até a reforma de 2003, em seus artigos $6^{\circ}$ e 112 . Para a sua concretização, se exigiria, no entanto, que a CTC exercesse de fato suas funções, Também previstas na LEP (arts. $5^{\circ}$ e $\left.6^{\circ}\right)$. (SÁ, 2010, p. 213)

Alvino de Sá (2010, p. 214-215) também propõe que se mude o nome da Comissão Técnica de Classificação (CTC) para Comissão técnica Interdisciplinar (CTI) e indica a sistematização de suas novas atribuições. Assim, passariam a ser as funções das novas Comissões Técnicas Interdisciplinares (atuais CTC):

a) realizar avaliação técnica interdisciplinar da pessoa, personalidade, histórico pessoal, e antecedentes do apenado, quando da chegada deste ao presídio, a fim de conhecer e definir seu perfil, para orientar a individualização da execução;

b) elaborar os programas individualizadores de execução de pena, preocupando-se em ajustá-los ao perfil dos presos;

c) acompanhar esses programas, revê-los, atualizá-los e avaliar sua eficácia;

d) realizar a avaliação técnica interdisciplinar da conduta dos presos, sempre devidamente assessorada pelos profissionais de segurança, avaliação essa da qual faria parte o "atestado de boa (ou má) conduta", para instruir os pedidos de benefícios. 


\section{CONCLUSÕES}

A Reforma Penal de 1984 instituiu as regras que hoje regulam o sistema progressivo de execução da pena no Brasil. A Reforma sofreu influencia direta do moderno direito penal da culpabilidade e conferiu autonomia ao Direito da Execução Penal por meio da edição da Lei de Execução Penal dissociada do Código Penal. A Reforma ainda procurou regulamentar um sistema preocupado em criar condições para que o egresso possa ter as mínimas de se reintegrar no seio social após o cumprimento da pena imposta.

O sistema de execução penal instituído no Brasil em 1984 baseia-se no cumprimento das regras e restrições impostas pela sentença condenatória e na capacidade de adaptabilidade do condenado a este sistema. O objetivo maior da execução penal é gradualmente recuperar e reeducar o condenado para impor a ele uma pena progressivamente de menor intensidade, pois somente penas progressivas fazem sentido em um sistema que busca preparar o egresso para convívio em liberdade.

O regime penal regula a parcela de liberdade que necessariamente deve ser restringida para efetivar os dispositivos da sentença condenatória. A progressão é realizada através da passagem do regime mais rígido, o fechado, para os de menor rigidez, semiaberto e aberto respectivamente, até a concessão do livramento condicional.

A sentença definirá a duração total da pena, a modalidade (reclusão ou detenção) e o seu regime inicial de cumprimento (nos termos dos artigos 33 e 59 do CPB), em respeito aos parâmetros de "quantidade", "qualidade", e "intensidade de sofrimento".

Iniciado o processo de execução, o condenado estará sujeito à jurisdição da Vara responsável pela execução penal, cujo Magistrado será o encarregado de tornar efetivos os dispositivos da sentença e de regular o cumprimento da pena. Especificamente é este Juiz quem decidirá a respeito dos pedidos de progressão, regressão, livramento condicional e dos incidentes de execução.

A Constituição Federal de 1988 prevê o respeito aos princípios da Personalidade e da Individualização da Pena durante as fases de conhecimento e de execução. Então, é imperativo que a execução da pena também se realize sob orientação cientifica, pois 
a pena deve ser aplicada respeitando o binômio necessidade/suficiência para a reprovação e prevenção do crime, e ainda deve compatibilizar o punir com o humanizar. Assim, será feita a definição do regime mais adequado a cada o momento da execução.

No início do cumprimento da pena os condenados devem ser submetidos a procedimento de classificação, de modo a indicar o tratamento em razão de sua personalidade (artigos $5^{\circ}$ e $9^{\circ}$ da Lei de Execução Penal). Após o cumprimento de um lapso temporal mínimo, o condenado pode então progredir para um regime menos rígido, conforme o "mérito" apresentado durante a execução da sentença ( $§ 2^{\circ}$ do artigo 33 do CPB).

No sistema originalmente proposto pela LEP, o mérito no curso da execução seria aferido considerando o resultado do exame criminológico, o parecer da Comissão Técnica de Classificação, a avaliação do comportamento e do desempenho no trabalho (dentre outros) e pela verificação das condições pessoais e personalidade compatíveis ou não com o novo regime.

Nesse sistema, o exame criminológico (apesar de suas limitações já observadas ao longo do trabalho) era de fundamental importância não somente para a classificação inicial como também no momento de progressão para regime mais bando.

No entanto, o legislador brasileiro resolveu acabar com a obrigatoriedade do exame para concessão da progressão de regime. Alguns dos motivos que levaram o Poder Executivo Federal a propor as alterações na Lei de Execução Penal de modo a tentar compatibilizar o texto legal à triste realidade vivida pelo sistema penitenciário brasileiro ${ }^{31}$

\footnotetext{
${ }^{31}$ Mesmo no Distrito Federal, cujo sistema penitenciário é mais bem estruturado se comparado ao restante do país, tais problemas apontados ao longo deste trabalho também podem ser observados na prática, ainda que em menor proporção. O primeiro aspecto diz respeito ao pessoal encarregado da custodia dos presos, pois ainda há Agentes da Policia Civil do Distrito Federal lotados no Sistema Penitenciário. Em segundo lugar, o DF não possui estabelecimentos penais adequados para a execução das penas em regime semiaberto, uma vez que os dois presídios destinados a tal, o CIR - Centro de Internamento e Reeducação - e o CDP - Centro de Detenção Provisória - não são efetivamente estabelecimentos do tipo colônia penal agrícola ou similar, assim, os internos são beneficiados com trabalho externo e transferidos para o CPP - Centro de Progressão Prisional - na medida da disponibilidade de vagas do local. Aqui temos um terceiro problema: como o estado não disponibiliza uma estrutura para garantir o acesso ao trabalho dentro do sistema penitenciário, os presos em regime semiaberto passam a trabalhar em estabelecimentos externos, públicos e privados, e só retornam para o repouso noturno e aos finais de semana, assim, tal regime constitui na prática uma espécie de regime aberto. Em último lugar: não há no DF a Casa do Albergado (ou estabelecimento semelhante) para o cumprimento da pena em regime aberto, assim, a solução encontrada é conceder a prisão domiciliar ao interno que reunir condições para progredir ao regime aberto.
} 
foram apontados no presente trabalho. A falta de investimentos para a construção de estabelecimentos prisionais adequados, a escassez de recursos para a contratação e treinamento de pessoal especializado, e a deficiência estrutural do sistema penitenciário brasileiro são uma triste realidade e inviabilizam o cumprimento efetivo de diversos dispositivos originalmente previstos na Lei de Execução Penal.

Este cenário e o costume das autoridades brasileiras em apresentar soluções paliativas para os problemas relacionados ao aumento nos índices de violência foram os fatores primordiais que levaram o legislador a editar a Lei 10.792 em $1^{\circ}$ de dezembro de 2003.

Infelizmente, em nossa visão, a referida lei adotou o caminho mais simples, ou seja, acabar com a obrigatoriedade do exame criminológico e do parecer da CTC e reduzir as atribuições dessa Comissão ao invés de investir em melhorias nos estabelecimentos prisionais e no reaparelhamento dessas comissões.

Notamos que, com a edição desse diploma legal, o poder público procurou dar uma resposta ao anseio da sociedade de enrijecer o tratamento dos presos pertencentes a organizações criminosas envolvidos com ondas de violência dentro e principalmente fora dos presídios, o que se deu com a criação de regras rígidas e instituição do Regime Disciplinar Diferenciado. Por outro lado, de uma forma silenciosa para esta mesma sociedade, o legislador procurou maquiar o problema superlotação carcerária existente nos diversos estados brasileiros. Procurou amenizar-se este problema por meio da flexibilização nas exigências para concessão da progressão de regime prisional e, com consequente liberação de vagas em estabelecimentos penais destinados ao regime fechado, onde a situação era e ainda continua mais crítica.

Neste particular, a forma encontrada pelo legislador foi suprimir a obrigatoriedade da análise mais aprimorada dos aspectos subjetivos dos condenados postulantes à progressão de regime prisional. Tal avaliação, que antes se realizava com base nas informações e dados obtidos por meio do exame criminológico e nos pareceres das Comissões Técnicas de Classificação, demandava a manutenção de uma estrutura composta por pessoal especializado multidisciplinar encarregado pela elaboração desses pareceres técnicos e acabava por tornar mais lenta e criteriosa a avaliação dos requisitos subjetivos do 
condenado nos pedidos de progressão. Por fim, o exame criminológico realizado para fins de instrução dos pedidos de progressão de regime ainda acabava por indicar que diversos condenados não possuíam condições de cumprir o restante da pena em regime menos rígido porque o estado não estava cumprindo sua função de prover o mínimo de condições para uma execução satisfatória da pena privativa de liberdade.

Com o fim da obrigatoriedade do Exame Criminológico somos forçados a admitir que é cada vez mais difícil se fazer uma real avaliação das condições subjetivas do apenado durante a execução da pena privativa de liberdade de modo a subsidiar a adoção de medidas efetivas para melhorar a capacidade de reinserção e reintegração do egresso ao convívio social. A Lei 10.792/2003, ao reduzir as atribuições da CTC e abolir a avaliação do mérito, colaborou para isso e ainda fez com que se deixasse de alimentar a já pobre fonte de dados sobre os aspectos subjetivos dos condenados recolhidos ao sistema penitenciário brasileiro.

Após a análise do posicionamento doutrinário e jurisprudencial sobre o assunto diante do sistema que se encontra instituído, consideramos que a nova redação do artigo 112 da Lei de Execução Penal não proibiu a realização do exame criminológico, apenas afastou a sua obrigatoriedade, dando mais liberdade ao Magistrado no momento de decidir. Realizando uma interpretação sistemática dos comandos do artigo $8^{\circ}$ da Lei de Execução Penal e do artigo 33, $\S 2^{\circ}$, do Código Penal, em consonância com os princípios de individualização da pena a Constituição Federal de 1988, podemos encontrar fundamentos legais para justificar a análise do mérito do condenado nos pedidos de progressão de regime.

Entendemos que o Juiz deva solicitar laudos periciais e pareceres para fundamentar sua decisão sobre os pedidos de progressão diante das peculiaridades do caso concreto, sempre que se mostrar necessária uma avaliação mais detalhada da personalidade do criminoso. Salientamos que este também é o atual posicionamento jurisprudencial acerca do assunto apresentado pelo Supremo Tribunal Federal (Súmula Vinculante 26 STF) e também pelo Superior Tribunal de Justiça (Súmula 439 do STJ)

Entendemos ainda, que o atestado de bom comportamento carcerário é insuficiente para demonstrar a capacidade do condenado para cumprir o restante da pena em regime menos rígido sem que o mesmo venha a frustrar os fins da execução. 
Consideramos que autores de crimes praticados com violência ou grave ameaça a pessoa, crimes hediondos e crimes sexuais deveriam ter suas condições pessoais obrigatoriamente avaliadas através do exame criminológico ou através de uma avaliação interdisciplinar da conduta nos moldes propostos por Alvino de Sá (2010, p. 211 a 215). Esta avaliação seria obrigatória em razão da reprovabilidade social desse tipo de conduta e para evitar ao máximo os casos de reincidência, principalmente nos casos de crime sexual onde a vítima sofre um trauma irrecuperável.

Também consideramos importante a adoção de tais procedimentos sempre que se identificar que o condenado apresenta reiterada atividade delitiva na prática criminosa. Nestes casos, há concreta demonstração de periculosidade do agente que apresenta personalidade desviada para pratica delitiva. Assim, deve necessariamente ser melhor avaliado antes de obter novos benefícios por não demonstrar capacidade e/ou vontade de se reintegrar ao seio social.

Por fim, anotamos que os projetos de mudança na Lei de Execução Penal geralmente apresentam uma visão limitada da questão penal e por esse motivo não conseguirão mudar o triste quadro da violência que assola o país. Esses projetos, que em um momento pretendem tornar sistema executório mais severo e em outro momento buscam torná-los menos rígido, são guiados por interesses políticos e buscam dar uma solução paliativa a problemas pontuais e, dessa maneira, não conseguem implementar melhorias efetivas no sistema penitenciário brasileiro.

Fechamos nosso trabalho com as palavras do eminente professor Sérgio Marcos de Moraes Pitombo (1996), que muito oportunamente observava que "emendar esse ou aquele dispositivo, acrescentar preceitos ou revogar outros. Tudo exsurge desútil, sem o despertar para a simples realidade: a execução penal diz com a paz pública." 


\section{REFERÊNCIAS BIBLIOGRÁFICAS}

AlbuQuerque, J. B. Torres de. Alterações na Lei de Execução Penal e no código de processo penal. São Paulo: Mundo Jurídico Editora, 2004.

ALENCAR, Ana Valderez A. N. de \& RANGEL, Leyla Castello Branco. Execução penal: Lei $\mathrm{n}^{\circ}$ 7210, de 11-07-84. Texto da lei anotado e indexado, anteprojetos, histórico (tramitação legislativa). Brasília: Senado Federal, Subsecretaria de Edições Técnicas, 1985.

AQUOTTI, Marcus Vinícius Feltrim e PINATTO, Bruna Fernandes. A Importância do Exame Criminológico na individualização executória da pena. São Paulo: Instituto Brasileiro de Ciências Criminais, 21 de Agosto de 2009. [Internet] Disponível em: http://www.ibccrim.org.br/site/artigos/_imprime.php?jur_id=10085. Acesso em 02 de setembro de 2009.

ARAÚJO, Cláudio Th. Leotta de e MENEZES, Marco Antônio de. Em defesa do exame criminológico. Instituto Brasileiro de Ciências Criminais, Boletim IBCCRIM No 129 Agosto / 2003. Disponível em <http://www.ibccrim.org.br/site/boletim/_imprime.php? id=97\&idBol=149> Acesso em 02 de setembro de 2009

BITENCOURT, Cézar Roberto. Regimes Penais e Exame Criminológico. In: Revista dos Tribunais, Volume 638. São Paulo: Revista dos Tribunais, dezembro de 1988, p. 260-269

COSTA, Álvaro Mayrink da. Exame criminológico: execução penal. $4^{\circ}$ edição, Rio de Janeiro: Editora Forense, 1993.

DOTTI, René Ariel. A Pena de Prisão. In: Bases e alternativas para o sistema de penas. $2^{\circ}$ Edição. São Paulo: Editora Revista dos Tribunais, 1998, p. 31-127.

A reforma penal e penitenciária 25 anos depois (A recepção das leis n. ${ }^{\circ}$ s 7.209 e 7.210/84 à Constituição de 1988) Disponível em: http://www.parana_online.com.br/canal/direito_e_justica/news/386422/?noticia=A+REFO RMA+PENAL+E+PENITENCIARIA+25+ANOS+DEPOIS+FINAL. Acesso em 12 de outubro de 2009.

Princípios fundamentais na reforma da execução penal. In: Anais do $1^{\circ}$ Congresso Brasileiro de Política Criminal e Penitenciária, Vol. 2. Brasília: Ministério da Justiça, Conselho Nacional de Política Penitenciária, 1982. p. 599-609

FRAGOSO, Heleno Claudio. Direito dos presos: Os problemas de um mundo sem lei. In: Direitos dos presos. Rio de janeiro: Forense, 1980. p. 1-46.

GOMES, Luiz Flávio; ALMEIDA, Patrícia Donati; e RAMOS, Elisa Maria Rudge. Progressão de regime: laudo psicológico versus exame criminológico? 14 de maio de 2009. [Internet] Disponível em http://www.lfg.com.br/public_html/article.php? story=20090511120729528 Acesso em 17 de dezembro de 2010.

GOUlaRT, José Eduardo. Princípios informadores do Direito da Execução Penal. São Paulo: Revista dos Tribunais, 1994. 
JORGE, Estêvão Luís Lemos. Exame criminológico como forma de individualização da pena e concessão de benefícios ao reeducando. In: Âmbito Jurídico, $\mathrm{N}^{\circ} 30$. Rio Grande: 2006 [Internet]. Disponível em: http://www.ambito-juridico.com.br/site/index.php? n_link=revista_artigos_leitura\&artigo_id=1102. Acesso em 18 de dezembro de 2010.

Paulo: Instituto Brasileiro de Ciências Criminais, 2005. [Internet]. Disponível em: <http://www.ibccrim.org.br/site/artigos/_imprime.php?jur_id=9175> Acesso em $17 \mathrm{de}$ dezembro de 2010

KÖHN, Edgar. Princípios e regras e sua identificação na visão de Robert Alexy. Boletim Jurídico, ano 4, $\mathrm{N}^{\circ}$ 188. Uberaba: 2006. [Internet]. Disponível em: <http://www.boletimjuridico.com.br/ doutrina/texto.asp?id=1440> Acesso em: 26 de dezembro de 2010.

KUEHNE, Maurício. Alterações à execução penal: Primeiras impressões. Florianópolis: Ministério Público de Santa Catarina, 2004a. [Internet]. Disponível em: http://www.mp.sc.gov.br/portal/site/portal/portal_detalhe.asp?campo=2247, acesso em 21 de novembro de 2010

Lei de Execução Penal Anotada. $4^{\circ}$ edição. Curitiba: Editora Juruá, 2004b.

Teoria e pratica da aplicação da pena. Curitiba: Editora Juruá, 1995.

LYRA, Roberto. Projetos e anteprojetos de código penitenciário. Rio de Janeiro: Editora UFRJ, 1978.

MARANHÃO, Odon Ramos, Os psicotestes no exame criminológico. In: Ciência Penal, Vol. 3, Fascículo 3. São Paulo: Ciência Penal, 1976. p. 17-47

Revista dos Tribunais, 1981. p. 41-50

Psicologia do Crime e a Lei 6.416/77. $1^{\circ}$ Edição. São Paulo:

MORAES, Rodrigo Iennaco de, A supressão do exame criminológico como (mais um) obstáculo à efetividade da execução penal: revisitando o paradigma behaviorista. In: Âmbito Jurídico. Rio Grande: 2004. [Internet] Disponível em: http://www.ambitojuridico.com.br/pdfsGerados/artigos/5012.pdf. Acesso em 17 de dezembro de 2010.

PEREIRA, Roberto Bandeira e STRECK, Lenio Luiz. Representação por inconstitucionalidade da Lei Federal n. ${ }^{\circ}$ 10.792/03, naquilo que alterou o art. 112, caput, da Lei de Execução Penal, visando a tutela da ordem jurídica e dos interesses sociais e difusos. Porto Alegre: Ministério Público do Estado do Rio Grande do Sul, 05 de Janeiro de 2006. [Internet] Disponível em: http://www.mp.rs.gov.br/areas/atuacaomp/ anexos_noticias/representacaopgr.doc. Acesso em 17 de dezembro de 2010.

PITOMBO, Sérgio Marcos de Moraes. Conceito de Mérito, no Andamento dos Regimes Prisionais. In: Revista Brasileira de Ciências Criminais, $\mathrm{N}^{\circ}$ 27. São Paulo: Instituto Brasileiro de Ciências Criminais, 1999. p. 149-158. [Internet] Disponível em: <http://www.sergio.pitombo.nom.br/index.php> Seção de Artigos. Acesso em 31 de agosto de 2010. 
PITOMBO, Sérgio Marcos de Moraes. Os Regimes de Cumprimento de Pena e o Exame Criminológico. In: Revista dos Tribunais, Volume 583. São Paulo: Revista dos Tribunais, 1984, p. 312-315. [Internet] Disponível em: <http://www.sergio.pitombo.nom.br/ index.php> Seção de Artigos . Acesso em 31 de agosto de 2010.

Período Republicano 1935 - 1996. São Paulo: 1996. [Internet] Disponível em: <http://www.sergio.pitombo.nom.br/index.php> Seção de Estudos Inéditos. Acesso em 31 de agosto de 2010.

QUEIROZ, Hênio Azevedo de. O exame criminológico e a Lei da execução penal. In: Anais do $1^{\circ}$. Congresso Brasileiro de Política Criminal e Penitenciária. Volume 2. Brasília: Ministério da Justiça, Conselho Nacional de Política Penitenciária, 1982.

RANGEL, Leyla Castello Branco \& NOGUEIRA, Fernando Giuberti. Lei de Execução Penal: Projeto de Lei No 1657, de 1983. Brasília: Senado Federal, Subsecretaria de Edições Técnicas, 1983.

REALE JUNIOR, Miguel e outros. Penas e medidas de segurança no novo Código Penal. Rio de Janeiro: Editora Forense, 1985.

ROIG, Rodrigo Duque Estrada. Direito e prática histórica da execução penal no Brasil. Rio de Janeiro: Editora Revan, 2005.

SÁ, Alvino Augusto de. Criminologia Clínica e Psicologia Criminal. $2^{\circ}$ edição. São Paulo: Revista dos Tribunais, 2010.

SILVA, Marcelo Gomes. Fim do Exame Criminológico? In: Atuação - Revista Jurídica do Ministério Público Catarinense, $N^{\circ}$ 2. Florianópolis: Ministério Público de Santa Catarina, 2004. p. 183 a 189. [Internet] Disponível em http://www.mp.sc.gov.br/portal/site/portal/ portal_detalhe.asp?campo=2636 Acesso em 17 de dezembro de 2010.

SILVEIRA, Alípio. O Exame Médico-Psico-Social na Justiça Penal. In: Os estabelecimentos penais e o juízo das execuções criminais. São Paulo: Sugestões Literárias, 1965. p. 57-113

TUCCI, Rogério Lauria. Progressão na execução de penas privativas de liberdade (Breve Estudo Sistemático). In: Revista dos Tribunais, Vol. 630. São Paulo: Revista dos Tribunais, 1988. p. 269-278 


\section{BIBLIOGRAFIA DE APOIO}

ALMEIDA, Luiz Roberto de \& MONTEIRO DOS SANTOS, Evaldo Veríssimo. O exame criminológico. São Paulo: Lex, 1975.

CASTILHO, Ela Wiecko Volkmer de. Controle da legalidade na execução penal. Porto Alegre: Sérgio Fabris, 1988.

COSTA, Armando. A condição jurídica do sentenciado e a interdição legal. Rio de Janeiro: Livraria Jacintho, 1936.

FARIAS, Vilson. O Exame Criminológico na Aplicação da Pena. In: Revista Brasileira de Ciências Criminais, $N^{\circ}$ 15. São Paulo: Instituto Brasileiro de Ciências Criminais, 1996, p. 269-298

FRANK, Pedro Ernany Pereira. Exame Criminológico. In: Revista do Ministério Público do Rio Grande do Sul, Vol. 3. Porto Alegre: Ministério Público do Rio Grande do Sul, 1974, p. $57-65$

FURUKAWA, Nagashi. O fim do exame criminológico. In: Jornal O Estado de São Paulo, Espaço Aberto. São Paulo: 2004. p. A2

ISOLDI FILHO, Carlos Alberto da Silveira. Exame criminológico, parecer da CTC e a nova lei n. 10.792/03. Governador Valadares: Nova Criminologia, 2006. [Internet] Disponível em: < http://www.novacriminologia.com.br/artigos/leiamais/default.asp ?id=1535 > Acesso em 19 de setembro de 2009.

LAURIA, Thiago. É necessário o exame criminológico para concessão de progressão de regime e livramento condicional? Belo Horizonte: Jurisway, 2006. [Internet] Disponível em: <http://www.jurisway.org.br/v2/dhall.asp?id_dh=71 > Acesso em 12 de dezembro de 2010 .

LOPES JR., Aury. A (im)prestabilidade jurídica dos laudos técnicos na execução penal. In: Boletim IBCCRIM No 123. São Paulo: Instituto Brasileiro de Ciências Criminais, 2003, p. $11-13$

MARANHÃO, Odon Ramos. Psicologia do crime. $2^{\text {o }}$ edição. São Paulo: Malheiros, 1995.

PITOMBO, Sérgio Marcos de Moraes. Ainda o Exame Criminológico. São Paulo: Tribuna do Advogado, 1985.

PORFÍRIO, Fernando. Suzane Richthofen deve passar por exame criminológico. São Paulo: 2009. [Internet] Disponível em: <http://www.conjur.com.br/2009-mai-25/suzanerichthofen-passar-exame-criminologico>. Acesso em: 01 de jun. 2009.

PRADO, Fabiana Lemes Zamalloa do. Execução penal e garantismo: as alterações introduzidas na lei de execuções penais sobre o exame criminológico. In: Boletim IBCCRIM Nº 146. São Paulo: Instituto Brasileiro de Ciências Criminais, 2005 p. 6-8

RANCO, Alberto Silva. Meia ilegalidade. In: Boletim IBCCRIM N ${ }^{o}$ 123, São Paulo: Instituto Brasileiro de Ciências Criminais, 2003. p. 2-3 
REALE JUNIOR, Miguel. Tentativa de eliminação do critério da periculosidade. In: Boletim IBCCRIM No 140. São Paulo: Instituto Brasileiro de Ciências Criminais, 2004. p. 2

RODRIGUES, Anabela Miranda. A posição jurídica do recluso na execução da pena privada de liberdade - seu fundamento e âmbito. Coimbra: Universidade de Coimbra, 1982.

SÁ, Alvino Augusto de. A Recuperação dos Sentenciados e a Questão do Exame Criminológico Versus Parecer das Comissões Técnicas de Classificação. In: Revista Brasileira de Ciências Criminais, $\mathrm{N}^{\circ}$ 13. São Paulo: Instituto Brasileiro de Ciências Criminais, 1996, p. 203-217;

SÁ, Alvino Augusto de. Considerações Acerca do Projeto de Reforma do Código Penal e de uma Possível Reforma da Lei de Execução Penal. In: Boletim IBCCRIM No 97, São Paulo: Instituto Brasileiro de Ciências Criminais, 2000, p. 3-5.

SHECAIRA, Sérgio Salomão. O Exame Criminológico e a Execução de Pena. In: Cadernos de Advocacia Criminal, vol. 1, N². Porto Alegre: 1988. p. 36-41.

SCHMIDT, Andrei Zenkner. Crônica acerca da extinção do exame criminológico. In: Boletim IBCCRIM No 134. São Paulo: Instituto Brasileiro de Ciências Criminais, 2004. [Internet] Disponível em: http://www.ibccrim.org.br/site/boletim/imprime.php?id=2404 \&idBol=163. Acesso em 02/09/09.

WUNDERLICH, Alexandre. O suplício de tântalo: a Lei n $^{\circ}$. 10.792/02 e consolidação da política criminal do terror. Boletim IBCCRIM No 134. São Paulo: Instituto Brasileiro de Ciências Criminais, 2004. p. 6 